\title{
Nagyfeloldású lokalizációs mikroszkópia több modalitásban
}

\author{
Doktori értekezés
}

Szerző:

Gajdos Tamás

Témavezető:

Dr. Erdélyi Miklós

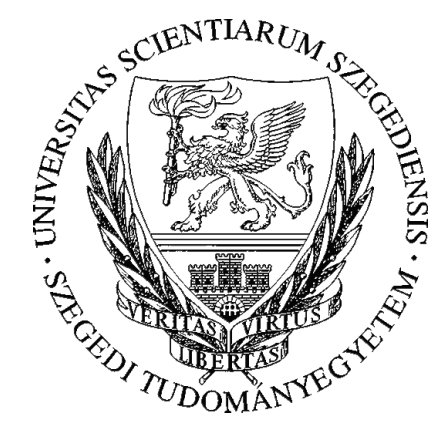

Fizika Doktori Iskola

Optikai és Kvantumelektronikai Tanszék

Szegedi Tudományegyetem

Szeged 



\section{Tartalomjegyzék}

Rövidítések jegyzéke 5

\begin{tabular}{ll}
\hline 1. Bevezetés & 7
\end{tabular}

2. Tudományos elözmények $\quad 8$

2.1. Fluoreszcencia tulajdonságai . . . . . . . . . . . . . . . . . . . . . 8

2.2. Fluoreszcens mikroszkópia . . . . . . . . . . . . . . . . . . . . . 13

2.3. Feloldási határ . . . . . . . . . . . . . . . . . . . . . . . . . . 18

2.4. Szuperrezolóciós technikák . . . . . . . . . . . . . . . 20

2.4.1. Pásztázáson alapuló szuperrezolúciós technikák . . . . . . . . . . 22

2.4.2. Széleslátóterü, lokalizáción alapuló szuperrezolúciós technikák . . . 23

2.5. Feloldás értelmezése az SMLM technikákban . . . . . . . . . . . . . . 26

2.6. Modalitások az SMLM technikákban . . . . . . . . . . . . . . . . . . . 28

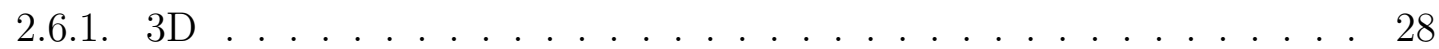

2.6.2. Polarizáció és anizotrópia . . . . . . . . . . . . . . . . . . 32

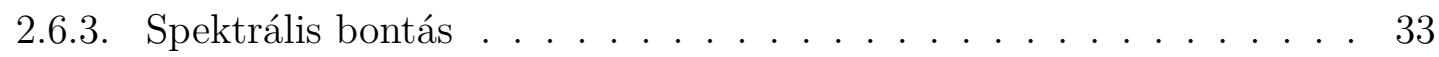

2.7. Modalitások összehasonlítása az SMLM technikákban . . . . . . . . . . . . 34

\begin{tabular}{ll}
\hline 3. & Célkitüzés \\
\hline
\end{tabular}

4. Módszerek és eszközpark 37

4.1. Gerjesztés és nyalábkondicionálás . . . . . . . . . . . . . . . . . . . . 37

4.2. Mikroszkóp váz . . . . . . . . . . . . . . . . . . . . . . . . . . . . . . . . . 38

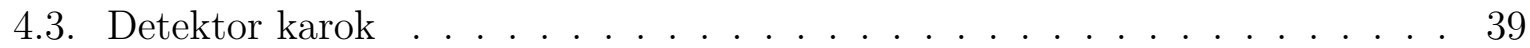

4.4. LSM Upgrade Kit . . . . . . . . . . . . . . . . . . . . . . . . . . . . . . . . . 39

4.5. Szuperrezolúciós dSTORM képalkotás. . . . . . . . . . . . . . . . . . . 40

5. Új tudományos eredmények 41

5.1. Az Alexa Fluor 568 festék anti-Stokes fluoreszcencia tulajdonsága . . . . . 41

5.1.1. Összehasonlító festékelemzés . . . . . . . . . . . . . . . . 42

5.1.2. Az anti-Stokes fluoreszcencia EPI és dSTORM mérések során . . . 48

5.1.3. Az eredmények tézispontban megfogalmazva . . . . . . . . . . . . . 53

5.2. Multi-modális lokalizációs mikroszkóp megtervezése . . . . . . . . . . . . . 54

5.2.1. OSLO szimuláció . . . . . . . . . . . . . . . . . . . . . . . . . . . . 55

5.2.2. PSF vizsgálata a leképző karokban . . . . . . . . . . . . . . . . 57

$5.2 .3 . \quad$ PSF vizsgálata 3D megvalósításhoz . . . . . . . . . . . . . . . . . 59

5.2.4. Az eredmények tézispontban megfogalmazva . . . . . . . . . . . . . 61

5.3. Multimodális lokalizációs mikroszkóp kivitelezése . . . . . . . . . . . . . 62

5.3.1. Felépítés és beállítás . . . . . . . . . . . . . . . . . . . . . . . . . . . . . 62 66

5.3.2. Képalkotás és adatfeldolgozás . . . . . . . . . . . . . . . . . . . . 66

5.3.3. Mérési eredmények . . . . . . . . . . . . . . . . . . . . 69

5.3.4. Az eredmények tézispontban megfogalmazva . . . . . . . . . . . . . 77

5.4. Muslica indirekt repülöizom fehérjeatlasza . . . . . . . . . . . . . . . 78 
5.4.1. Biológiai probléma . . . . . . . . . . . . . . 78

5.4.2. Miofibrillumok dSTORM mérése, feldolgozása és kvantifikálása . . . 80

5.4.3. Az eredmények tézispontban megfogalmazva . . . . . . . . . . . . 83

6. Összefoglalás $\quad 85$

6.1. Bevezetés . . . . . . . . . . . . . . . . . . 85

6.2. Célok és kutatási módszerek . . . . . . . . . . . . . . . . . . . . . . . . . 86

6.3. Új tudományos eredmények . . . . . . . . . . . . . . . . . . . . 87

\begin{tabular}{lr}
\hline 7. Summary & 89
\end{tabular}

7.1. Introduction . . . . . . . . . . . . . . . . . . . . . . . . . 89

7.2. Objectives and methods . . . . . . . . . . . . . . . . . . . . . 90

7.3. New scientific results . . . . . . . . . . . . . . . . . . . . . . . 91

\begin{tabular}{ll}
\hline Köszönetnyilvánítás & 93
\end{tabular}

\begin{tabular}{ll}
\hline Publikációs lista & 94
\end{tabular}

\begin{tabular}{ll}
\hline Irodalomjegyzék & 96
\end{tabular} 


\section{Rövidítések jegyzéke}

4Pi. Két, egymással szembe fordított objektívből álló mikroszkóp

AFnnn. Alexa Fluor marketing festékcsalád, ahol az nnn tag általában festék abszorpciós maximumához tartozó hullámhosszát jelöli: AF647 $\rightarrow$ Alexa Fluor 647

AOTF. Acousto-Optic Tunable Filter

CLSM. Confocal Laser Scanning Microscopy

DOF. Depth Of Field, mélységélesség $D O F=n \lambda / N A^{2}$

(d)STORM. (direct) Stochastic Optical Reconstruction Microscopy

EMCCD. Electron Multiplying CCD, kamera

EPI. Epifluorescence, megvilágítási mód

FLIM. Fluorescence Lifetime Imaging Microscopy

FRET. Förster-Resonance Energy Transfer

FOV. Field Of View, képtér

(f)PALM. (fluorescent) PhotoActivated Localization Microscopy, lokalizációs technika

GFP. Green Fluorescent Protein, zöld fluoreszcens fehérje

GSDIM. Ground State Depletion followed by Individual Molecule return, lokalizációs technika

HILO. Highly Inclined and Laminated Optical sheet microscopy, megvilágítási mód

IRF. Instrument Response Function

Minflux. Minimal photon Flux, pásztázó nagyfeloldású mikroszkópos technika

NA. Numerikus Apertúra

PFS. Nikon Perfect Focus System, fókusztartó rendszer

PSF. Point Spread Function, az optikai rendszerre jellemző pontátviteli függvény. Mikroszkópiában: egy pontszerünek tekinthető fényforrás (fluoreszcens festék) detektorra leképzett képe. 
Rhnnn. Rhodamine struktúrájú festékcsalád, ahol az nnn tag a családon belüli elnevezést takarja: Rh110 $\rightarrow$ Rhodamine 110

ROI. Region Of Interest, leképzendő tartomány

SAF. Supercritical Angle Fluorescence

sCMOS. Scientific CMOS, kamera

SIM. Structrured Illumination Microscopy, struktúrált kivilágításos mikroszkóp

SLM. Spatial Light Modulator

SMLM. Single-Molecule Localization Microscopy, egymolekula lokalizáción alapuló mikroszkópos technikák gyüjtőneve

STED. STimulated Emission-Depletion miroscopy, pásztázó nagyfeloldású mikroszkópos technika

TCSPC. Time-Correlated Single-Photon Counting, idő-korrelált egyfoton számlálás

TIRF. Total Internal Reflection Fluorescence, megvilágítási mód 


\section{Bevezetés}

A bennünket körülvevő világ megismeréséhez és leírásához folyamatosan új megközelítéseket kell találni, új módszereket kidolgozni és a rendelkezésre álló eszközöket a mérési határukig eltolni. Az élettudományok eszköztárában előkelő helyen szerepel az optikai mikroszkópok már közel 400 éve. A folyamatos fejlesztéseknek köszönhetően megfigyelhetővé váltak a pár mikron, illetve mikron alatti mérettartományba eső biológiai struktúrák. Hatalmas előnye egy optikai mikroszkópnak, hogy a méréseket roncsolás-mentesen lehet elvégezi. A modern rendszerekkel valós időben, akár nanométeres precizitással vizsgálható egy élő sejtkultúra annak ellenére, hogy ehhez kőbe vésett határokat [1] kellett trükkökkel megkerülni.

Doktori tanulmányaim során lehetőségem volt bekapcsolódni a Szegedi Tudományegyetem első szuperrezolúciós, egymolekula detektáláson alapuló lokalizációs mikroszkópjának megépítésébe. Az elmúlt években részt vettem új mérési elrendezések kidolgozásában, interdiszciplináris kutatási együttmüködések kialakításában, és az általam ismert (vagy nem ismert) fizika és kapcsolódó tudományágak mélyebb megértésében.

Értekezésemben áttekintem azokat az alapokat, amire a fluoreszcens mikroszkópia és azon belül a feloldást javító technikák építenek. Áttekintem általánosan a fluoreszcencia tulajdonságait, a rá építhető mikroszkópos elrendezéseket, képalkotási technikákat, egészen a szuperrezolúcióig. Itt kiemelt hangsúlyt fektetek az alkalmazható modalitásokra, és a technika fotonlimitált természetét emelve ki. A célkitűzés után áttekintem az alkalmazott eszközöket és módszereket. Új tudományos eredményeimet négy alfejezetben foglalom össze, amelyek végén egy-egy tézispontot fogalmazok meg. 


\section{Tudományos elözmények}

Ebben a fejezetben áttekintem a tudományos előzményeket, amik segítik a dolgozat megértését, és amire építem azokat a célokat, amiket a célkitüzésben fogalmazok meg.

\subsection{Fluoreszcencia tulajdonságai}

Azt a fizikai folyamatot, amely során egy gerjesztett állapotból alap állapotba visszatérő atom vagy molekula fényt bocsát ki lumineszcenciának nevezzük. Ha a gerjesztett állapot foton elnyelődéssel jött létre, akkor fotolumineszcenciának nevezzük a relaxációs folyamatot, és a gerjesztett állapot alapján két fö kategória különböztethető meg. Fluoreszcenciáról akkor beszélünk, ha az alap állapotba relaxáció szinglett állapotból indul ki (az elektron párjától eltérő spinnel rendelkezett). A foszforeszcencia elnevezést akkor használjuk, ha a relaxáció triplett állapotból történik (az elektron párjával megegyező spinnel rendelkezett). Az utóbbi folyamat tiltott átmenet a kvantummechanika kiválasztási szabálya szerint, ami csak kis, de nem nulla valószínűséggel jöhet létre. Emiatt a két folyamat az alapján is elkülöníthető, hogy várhatóan mennyi időre van szüksége a gerjesztett elektronnak az alap állapotba történő visszatéréshez. Fluoreszcencia esetén ez a várható élettartam a 1 - 100 nanoszekundumos, míg foszforeszcencia esetén a milliszekundumos - szekundumos, sőt akár órás skálára is eshet.

A fluoreszcencia jelenségét már a középkorban is ismerték. Első ismert tudományos felhasználása Nicolás Mondares spanyol botanikus nevéhez köthető 1565-ből, aki egy korabeli májra ható gyógyszer drága alapanyagának ellenőrzéséhez használta, a hamisítás elkerüléséhez [2]. Az elkövetkező évtizedekben többen is vizsgálták a jelenséget, valamint bizonyos fluorit kristályokban is leírták azt. S bár a fény hullámhosszának eltolódását megfigyelték, azonban a jelenséget tévesen fényszóródásként magyarázták (pl. Sir David Brewster 1833-ban) [3, 4]. Sir John Hershell figyelte meg az 1800-as évek közepén azt, hogy kinin tartalmú átlátszó oldata napfény hatására kékes színben ragyogott [5]. A fluoreszcencia jelenségének első helyes leírása Sir George Gabriel Stokes nevéhez füződik. Megfigyelései alapján kikövetkeztette, hogy a gerjesztés során elnyelt- és a fluoreszcens anyag által kibocsátott fény hullámhossza különbözik [6]. Kísérletében a nap fényét prizmával felbontotta, majd a kinint tartalmazó fiolát elhúzta az így létrejövő spektrum mentén. A 
látható tartományban nem tapasztalt semmilyen jelenséget, míg az ibolyán túli szakaszon (ami már nem érzékelhető szemmel) az oldat Hershell tapasztalataihoz hasonlóan kéken világított [4]. Ezt a hullámhossz eltolódást, amely az elnyelt (abszorbeált) és a kibocsátott (emittált) fény között fellép, Stokes-eltolásnak nevezzük. Létrejötte legegyszerűbben a Kasha-szabállyal magyarázható:

- A foton elnyelődése során az elektron a gerjesztett állapot egy magasabb vibrációs szintjére ugrik.

- Belső konverzióval és a vibrációs állapotok közötti relaxációval az elektron a gerjesztett állapot legalacsonyabb vibrációs szintjére jut.

- A foton kibocsátás akkor jön létre, amikor erről az alacsonyabb energiaszintről az elektron újra alap állapotba (annak egyik vibrációs szintjére) lép [7].

Ez a belső relaxáció és konverzió adja a hullámhossz vörös eltolódását. Az alap- és gerjesztett állapotok ábrázolását a Jablonski-féle diagramon lehet szemléltetni [8]. A diagram mutatja a molekulában megtalálható energiaszinteket (elektron állapotok, vibrációs állapotok), és az energiaszintek közötti lehetséges átmeneteket, relaxációs utakat (2.1. ábra). A Kasha-szabály egyik következménye, hogy a kibocsátott fény hullámhossza független a gerjesztő fény hullámhosszától [9].

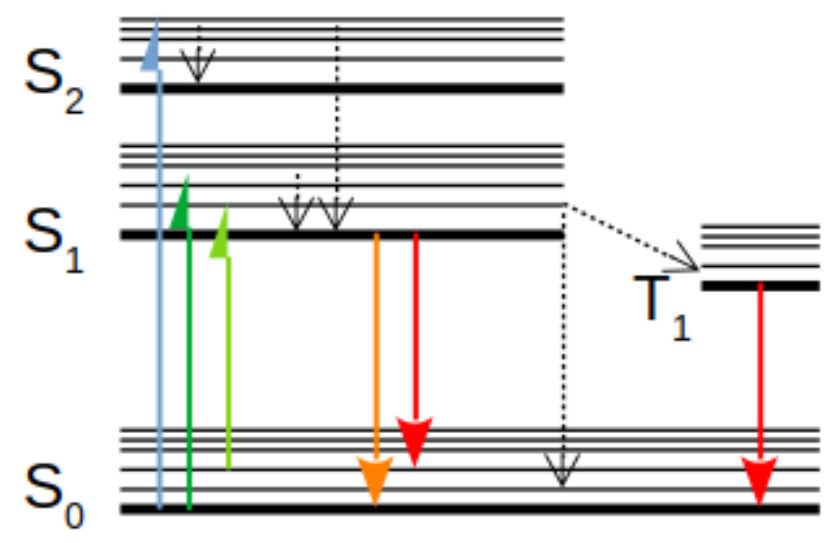

2.1. ábra. A fluoreszcencia és foszforeszcencia lehetséges átmenetei Jablonski diagramon ábrázolva. A nem sugárzó belsö átmeneteket és vibrációs állapotok közötti relaxációt fekete szaggatott nyíl jelöli. 
A hőmérséklet növelésével az alap állapot vibrációs szintjeinek betöltöttsége megnövekszik a Boltzmann eloszlás szerint. Tehát több lesz azon kiindulási állapotok betöltöttsége, ahonnan fotonelnyelés során gerjesztődhet az elektron. Ennek eredménye az, hogy az abszorpciós spektrum folytonos lesz, és elveszti vonalas jellegét. A gerjesztési és emissziós spektrumok az esetek többségében tükör szimmetrikusak. Ha ez nem teljesül, akkor az arra utal, hogy a fluoreszcencia élettartama alatt a molekula szerkezeti változáson esett át. A spektrumokat azzal a hullámhosszal jellemzik, ahol a maximum értéket felveszik. Abszorpciós maximumnak nevezzük azt a hullámhosszat, ahol az elnyelt fotonok száma a legnagyobb, míg emissziós maximumnak azt a hullámhosszat, ahol a gerjesztés hatására a létrejövő fluoreszcencia intenzitása a legnagyobb.

Az abszorpciós- és emissziós spektrumok mellett a fluorofóroknak (gyüjtőneve a fluoreszcenciával relaxálódó atomoknak, molekuláknak stb.) további három fontos tulajdonságuk van. Kvantumhatásfoknak nevezzük azt az arányt, amely megadja a kapcsolatot az elnyelt $\left(N_{a}\right)$ és a kibocsátott $\left(N_{e}\right)$ fotonok száma között. Értéke kiszámolható két átmeneti valószínüségből (fluoreszcens- $k_{f}$ és a nem sugárzásos- $k_{n r}$ ):

$$
\Phi_{f}=\frac{N_{e}}{N_{a}}=\frac{k_{f}}{k_{f}+k_{n r}} .
$$

Csak pár sürün használt szerves festék kvantumhatásfokát említeném [10, 11]: $\Phi_{R h 101}=$ $=0.96, \Phi_{R h 6 G}=0.95, \Phi_{A F 568}=0.69, \Phi_{A F 647}=0.33$. Fluoreszcencia élettartamnak nevezzük azt az időtartamot, amely alatt a gerjesztett állapotban lévő molekulák száma e-ad részére csökken. Értéke kiszámolható a korábban is említett két átmeneti valószínűségből

$$
\tau_{f}=\frac{1}{k_{f}+k_{n r}} .
$$

A korábban említett szerves festékekre [12] $\tau_{R h 101}=4,32 n s, \tau_{R h 6 G}=4,08 n s, \tau_{A F 568}=3,6 n s$, $\tau_{A F 647}=1$ ns. Az intenzitás időbeli változását a következő összefüggés adja meg:

$$
I(t)=I_{0} \exp ^{-t / \tau_{f}}
$$

Ahol $I(t)$ a fluoreszcencia intenzitás a $t$ időpillanatban, $I_{0}$ a fluoreszcencia intenzitás az abszorpció által meghatározott kezdeti időpontban. A fluoreszcencia élettartam érzékeny 
a közvetlen környezetre és az energiatranszfert lehetővé tevő kölcsönhatásokra. Bonyolult esetekben az intenzitás csökkenése csak több exponenciálissal (és több karakterisztikus élettartam súlyozott összegével) írható le [13].

A szerves festékeket molekula szerkezet alapján szokás családokba sorolni (rhodamine, cián, ...), ez nem összekeverendő az egyes gyártók által használt marketing családokkal (Alexa, Atto, ...). Egy fluorofór kiválasztásánál fontos szem előtt tartani továbbá annak fotostablitását is. A gerjesztési és relaxációs ciklusok során előfordulhat, hogy a fluorofór gerjesztett állapotban tartós szerkezeti változáson esik át. Ezt a folyamatot photobleachingnek nevezzük, és a végeredmény egy nem fluoreszcens termék.

A biológiai minták tartalmazhatnak olyan molekulákat is, amelyek fluoreszcensek UV közeli hullámhosszakon gerjesztve. Ezt a jelenséget autofluoreszcenciának nevezzük [14]. Kvantumhatásfoka alacsony, viszont a jelölésen alapuló technikák használata esetén ez egy nemkívánatos melléktermék, hiszen a keresett fluoreszcens jelhez egy mérhető hátteret ad. Hatása elsősorban kémiai úton csökkenthető [15]. Optikai módszerekkel egyedül a gerjesztő hullámhossz vörös felé tolásával és emiatt a fluoreszcens festék cseréjével (általánosan) lehet csökkenteni az ebből az effektusból származó hátteret.

Anti-Stokes fluoreszcencia - A Stokes-eltolódás a fluoreszcenciában egy általános jellemző, ami segítségével leírható a kibocsátott foton energiájának csökkenése az elnyelt foton energiájához képest. Azonban létezik egy másik folyamat is, amit felkonverziónak vagy anti-Stokes fluoreszcenciának hívnak. Ebben az esetben az energia viszonyok megfordulnak, és az elnyelt foton energiája kisebb lesz, mint a kibocsátott fotoné.

A folyamat termodinamikai hátteréről heves vita alakult ki 1946-ban Pringsheim és Vavilov között, amit a végén Landau zárt le még ugyanabban az évben [16]. Mint általában minden örökmozgó és energiamegmaradást látszólag sértő folyamatnál, itt is meg kell keresni, hogy a hiányzó energia honnan származik. Ennek forrás lehet termikus [17] 2.2 d-e) vagy fotonikus, valós [18, 19] és virtuális [20] energiaszinteket felhasználva (2.2.a-b). Lantanida alapú nanorészecske az f-elektronpályán keresztül gyüjtheti össze a környezetéből a gerjesztett állapothoz szükséges többlet energiát [21], amit egy akceptor festéknek átadva jön létre a fluoreszcencia.

Az egyfotonos folyamatok két modellel írhatóak le. Az első szerint az oldat vagy egy 
(a)

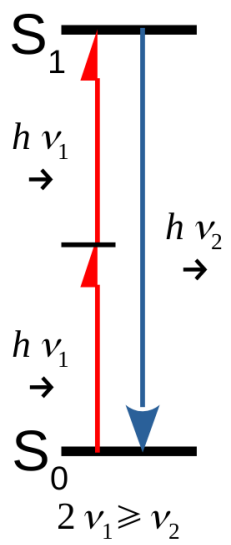

(b)

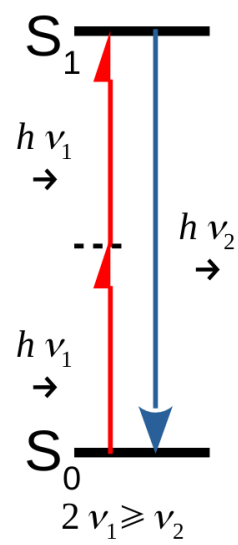

(c)

(d)



2.2. ábra. Sematikus ábrázolása a tipikus anti-Stokes folyamatoknak. Az (a) ábrán a két fotont elnyelését egy köztes valós energiaszint teszi lehetövé lantanidáknál. A (b) ábrán a kétfotonos folyamat virtuális energiaszintet használ. A (c) ábrán a késleltetett fluoreszcencia két triplett állapotú molekula ütközésén keresztül gerjesztődik (P-típus), a (d) ábrán a triplett állapotból vibrációs energiaszinteken keresztül gerjesztődik (E-típus), míg az (e) ábrán az alap állapot vibrációs energiaszintjeiről történik a gerjesztés.

másik anyag gerjesztődik, és ütközések következtében a célmolekulát $T_{1}$ állapotba gerjeszti. A $T_{1}$ állapot hosszú élettartama és hőmérsékleti aktiválás miatt a fluorofór átgerjesztődhet $S_{1}$ állapotba, ez akár szobahőmérsékleten is megtörténhet. Az $S_{0}$-ba történő relaxáció tehát a két gerjesztett állapotból történhet, az élettartama a foszforeszcencia élettartamával mérhető össze [22]. Ezt a gerjesztési modellt szokás E-típusú késleltetett fluoreszcenciának is nevezni [23, 24].

A második modell szerint a kiinduló állapot az $S_{0}$ energiasáv egyik vibrációs alszintje. Mivel a direkt $S_{0} \rightarrow S_{1}$ ugráshoz kevés az elnyelt foton energiája, ezért csak a legmagasabb energiával rendelkező vibrációs szintek vesznek részt a folyamatban, amik betöltöttsége a Boltzmann eloszlás szerint hőmérséklet függő. Emiatt a folyamatot forró energiasávos elnyelődésnek (hot band absorption) is szokás nevezni [25]. Az $S_{0}$-ba történő relaxáció ezek után már hasonló módon történik, mint „normál” fluoreszcenciánál. Az élettartam emiatt a fluoreszcenciáéval megegyező, és az emissziós spektrumban csak az $S_{1}$ relaxációs folyamat látható [22]. Egyedüli eltérés a folyamat nagyon alacsony hatáskeresztmetszetében van, ami erős hőmérséklet függést is mutat [26].

A második modell esetén, ha megvilágított anyag és környezete között nem jön létre 
hőátadás, akkor a forró energiasávos elnyelés és az azt követő fluoreszcencia a rendszer hütését vonja maga után. A folyamat irodalmában emiatt sok lézeres hütéssel kapcsolatos cikk található, illetve az elmúlt években biológiai alkalmazások is megjelentek [27, 21]. Több szerves festékre is kimutatták a forró energiasávos elnyelést, hol hőmérséklet mérésre, hol lézeres hütésre kihasználva a jelenséget (Rh101[26], Rh6G [22], Rh640[28], RhB[29], Oxazine 1[30], cián alapú festékek[31]).

A továbbiakban fluoreszcencia alatt mindig a „normál”, Stokes-eltolódáson alapuló fluoreszcenciát értem. Ha kiemelem, hogy felkonverziós fluoreszcencia, akkor a forró energiasávokat kihasználó, második modell szerint végbemenő, anti-Stokes fluoreszcenciát értem alatta.

\subsection{Fluoreszcens mikroszkópia}

Ha a vizsgálandó struktúra mérete kisebb, mint szemünk feloldási küszöbe, akkor további optikai elemeket kell használnunk, például egy mikroszkópot. A mikroszkóp főbb tulajdonságai közé tartozik a képalkotás módja, a fénygyưjtő képessége, az elérhető nagyítás és a feloldás. A felhasználási terület szerint ezek a tulajdonságok igen széles paraméterskálán mozoghatnak, és össze is vannak kapcsolva. Ha egyiket változtatjuk, akkor óhatatlanul egy másik tulajdonság értékét is változtatnunk kell. Leegyszerüsítve egy optikai mikroszkóp 4 alapvető alakotóelemből épül fel: fényforrás, objektív, tubus lencse (vagy okulár), és detektor. Ezekre a 2.1. táblázatban mutatok pár példát.

\begin{tabular}{|c|c|l|}
\hline Elem neve & Típusok & Főbb paraméterek \\
\hline \hline Fényforrás & izzó és kondenzor, led, lézer & $\begin{array}{l}\text { spektrum, teljesítmény, élettartam, koheren- } \\
\text { cia }\end{array}$ \\
\hline Objektív & lencsés vagy tükrös & $\begin{array}{l}\text { immerzió típusa, numerikus apertúra (NA), } \\
\text { fedőlemez korrekció, képsík korrekció, végte- } \\
\text { lenre korrigált-e }\end{array}$ \\
\hline Tubus lencse & objektív családhoz tervezve & fókusztávolság, egyéb korrekciók \\
\hline Detektor & pont, vonal, felület & $\begin{array}{l}\text { spektrális érzékenység, kvantum hatásfok, } \\
\text { erősítés módja, kiolvasás sebessége }\end{array}$ \\
\hline
\end{tabular}

2.1. táblázat. A táblázatban a négy fó mikroszkópalkotó elemet rendszerezem, kiemelve pár fontos tulajdonságot. 
Fluoreszcens mikroszkóp esetén azonban egy további optikai elemcsoport is megtalálható a rendszerben: a dikroikus tükör, a gerjesztési-, és az emissziós szűrő. Erre azért van szükség, mert a fluorofór intenzitása a gerjesztő fényéhez képest eltörpül ( $I_{\text {fluorofór }}<<$ $\left.<I_{\text {gerjesztő }}\right)$. Viszont a Stokes-féle eltolódás kihasználható, és így leválaszthatóvá válik a mintából érkező emissziós jeltől a gerjesztő fény, ami kontraszt növekedést eredményez. További megfelelően választott szűrők használatával érhető el az, hogy a megvilágításhoz használt fény már ne jusson el a detektorra. Így vizsgálhatóvá válnak olyan fluorofórok vagy autofluoreszcenciával rendelkező minták, amelyek alacsony kvantumhatásfokkal rendelkeznek.

Az optikai mikroszkópoknak sok változata fejlődött ki és a képalkotás módja szerint két fő kategóriát lehet meghatározni. Pásztázó konfokális mikroszkópról akkor beszélünk, amikor a vizsgálandó minta egy előre meghatározott mintázat szerint pontról-pontra, lépésenként kerül megvilágításra, majd az ezekből a pontokból származó fotonok a detektor felületén kerülnek összegyűjtésre. A pásztázás megvalósítható a minta (és a tárgyasztal) mozgatásával, amilyen megvalósításban az első konfokális mikroszkóp is müködött 1957-ben [13]. Hasonló eredmény érhető el az optikai útba helyezett mozgatható tükrök segítségével is, aminek előnye a rendszer megnövekedett stabilitása. Az utóbbi elrendezés látható a 2.3 . ábra bal felén: A gerjesztő fény (például lézer forrás) kollimáltan érkezik a mikroszkópba, és a fényútban található dikroikus tükrön visszaverődik. Ezek után keresztülhalad a szkennelő tükrökből álló nyaláb eltérítő elrendezésen, és az objektív a mintába fókuszálja azt a tükrök által meghatározott laterális pozícióban. A mintából származó fényt az objektív összegyűjti, és a szkennelésre használt tükrök „de-szkennelik” azt. (Vagyis a mozgó fókuszpontból származó fény ezek után ugyanazon az optikai úton fog tovább haladni.) Az emissziós jelet átengedi a dikroikus tükör, amit a tubuslencse egy változtatható méretű tủlyukra fókuszál, ami a detektor (fotoelektron sokszorozó cső vagy félvezető hibrid detektor) előtt található. A tűlyuk nem engedi át a fókuszfolton kívülről érkező fluoreszcens jelet, így érve el kontraszt növekedést. A detektor által összegyüjtött jelből és a szkennelő tükrök pillanatnyi állásából pixelenként összerakható a kép [13]. A technika hatalmas előnyét a tưlyuk által bevezetett szürés jelenti. A fókuszfolt z-irányú mozgatásával több sík is leképezhetővé válik, és így a 3D képalkotás megvalósítható.

A hagyományos leképzésen alapuló, széles látóterü mikroszkóp esetén a teljes leké- 



2.3. ábra. Bal oldalon a fluoreszcens pásztázó mikroszkóp sematikus modellje látható, míg jobb oldalon a fluoreszcens képalkotó mikroszkóp sematikus modellje. A gerjesztő fényt $\boldsymbol{E}$ (útja zöld színnel van jelölve) a dikroikus tükör $\boldsymbol{D} \boldsymbol{M}$ az objektív $\boldsymbol{O}$ felé tükrözi, ami megvilágítja a mintát. A mintából származó emissziós fényt (útja narancssárga színnel van jelölve) az objektív összegyüjti, keresztül halad a dikroikus tükrön, majd a detektorra fókuszálódik. Pásztázó esetben egy pozicionáló elemre $\boldsymbol{P}$ és egy detektor elötti tülyukra is szükség van, míg képalkotó esetben a gerjesztő fény útjába egy fókuszáló lencsét $\boldsymbol{L}$ kell behelyezni.

pezendő terület (Region of Interest, ROI) kerül megvilágításra, és az erről a területről keletkező kép (Field of View, FOV) a kamerán egyszerre jön létre. Ez az optikai elrendezés a 2.3. ábra jobb felén látható: Epifluoreszcens megvilágítás esetén a gerjesztő fényt egy lencsével az objektív hátsó fókuszsíkjába kell fókuszálni. Ebben az esetben a objektívból kollimált nyaláb lép ki, és a minta egy adott területét (térfogatát) világítja meg. Az ebből származó jelet az objektív összegyüjti, majd a gerjesztő fény leválasztásra kerül a dikroikus tükrön, és a tubuslencse képet hoz létre a detektoron (EMCCD vagy sCMOS kamera) az egyszerre világító fluorofórokról. A széleslátóterű mikroszkópok hatalmas előnye a konfokálisokkal szemben a sebesség, hiszen nem kell a ROI-t végigpásztázni a kép 
létrehozásához.

Azonban nem minden mintát lehet fluoreszcens mikroszkóppal vizsgálni. A biológiai minták jelentős hányada (például humán és állati sejtek, szövetek) látható tartományban szinte átlátszóak, nem tartalmaznak fluoreszcensen aktív molekulákat. A vizsgálandó minta azonban fluoreszcensé tehető, a lehetőségek közül két módot emelnék ki. A sejtek rákényszeríthetőek egy fluoreszcensen aktív fehérje (például GFP) expressziójára. A GFP fehérjének (aminek a felfedezését 2008-ban kémiai Nobel-díjjal jutalmazták) léteznek különböző színű variánsai is: YFP-sárga, RFP-vörös. Ugyancsak hasonló hatás érhető el immunhisztokémiai módszerekkel, specifikus kötéseket kihasználva. Ebben az esetben a célfehérjére vagy sejtalkotóra készített elsődleges antitest megkeresi a sejten belül a kapcsolódási helyét és egy másodlagos bejuttatja a kémiai kötéssel rákötött szerves festéket (például a korábban említett AF647). Az ezekkel a módszerekkel fluoreszcensen aktívvá tett biológiai minta már vizsgálhatóvá válik.

Mindkét módszer előnye, hogy bizonyos keretek között kiválasztható, hogy melyik célmolekulát melyik fluorofór jelölje. Ez lehetőséget ad a multiplexelésre, vagyis egy adott mintán belül többféle célmolekula tehető láthatóvá különböző színekben. A de-multiplexelés kétféle módon oldható meg mindkét képalkotási módban: egycsatornás elrendezés esetén szekvenciálisan, vagy többcsatornás elrendezést használva szimultán. Az egycsatornás esetben csak egy detektoron történik detektálás, ami változik az a gerjesztő fény hullámhossza és a detektor előtt használt sávszürő. Az egyes spektrális csatornák több felvételből, a beállítások kombinációjából állnak össze. A módszer előnye, hogy egyszerü megvalósítani, és nem kell több detektort összehangolni. Hátránya viszont az, hogy a mérési idő megnövekszik. A detektor karban lehetőség van egy további spektrális bontóelem (dikroikus tükör) használatával az emissziós spektrumok alapján a mintából érkező fluoreszcens jelet szétbontani. A spektrális csatornák hozzárendelhetőek egy-egy detektorhoz, amiből a többcsatornás rendszer előnye is látszódik, hogy egy időben készülhetnek el a felvételek, így a mérés gyors. Hátránya viszont az, hogy ügyelni kell az egyes detektor karban fellépő eltérő nagyságú detektálási hatékonyságokra.

Egy ilyen elrendezésben tipikusan három-négy festék különböztethető meg emissziós spektrumaik alapján attól függően, hogy az spektrumok mennyire fednek át [13]. Erre egy példa látható a 2.4 ábrán, amelyen csapatunk mikroszkópjának spektrális viszonyait 
ábrázoltam kettő elterjedt festékre, még a de-multiplexelés előtt. Az (a) spektrum mutatja az abszorpciós oldalt: folytonos vonallal a két gerjesztő lézer hullámhossza $(561 \mathrm{~nm}$ és 647nm) van jelölve, szaggatott vonallal a két szerves festék (AF568 és AF647) abszorpciós görbéje[32]. A fekete pöttyözött vonal a dikroikus tükör (Semrock Di01R405/488/561/635) transzmisszióját mutatja. A (b) spektrum az emissziós oldalt mutatja: a két színes vonal a két festék emissziós görbéjét jelöli, míg a fekete vonallal az emissziós szürő (Semrock FF01-446/523/600/677) transzmisszióját jelölöm. Ebben az esetben a gerjesztési oldalon (a) is (az 561nm-es lézerrel gerjeszthető az AF647 fluorofór) és az emissziós oldalon (b) is (az AF568 festék emissziója átlóg az AF647 festék emissziójába) észrevehető a festékek spektrumai között az áthallás.
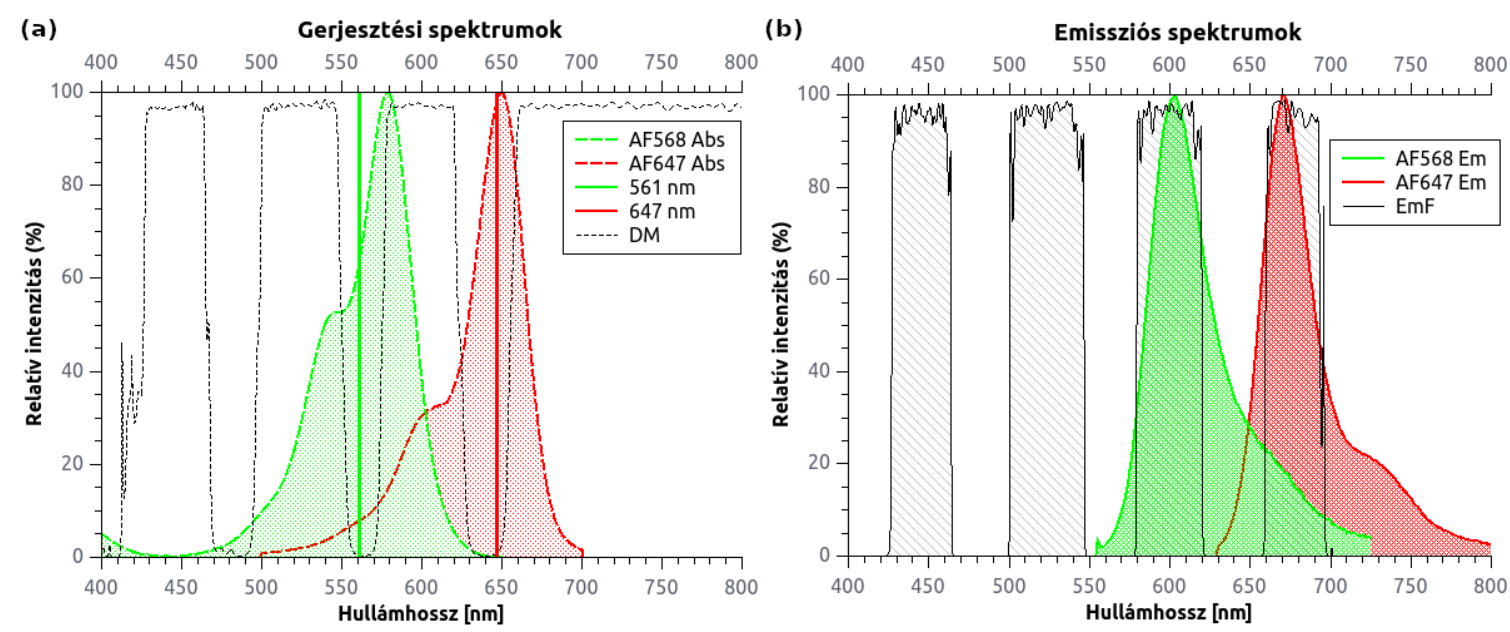

2.4. ábra. Gerjesztési (a) és emissziós (b) spektrumok egy fluoreszcens mikroszkópban. Vegyük észre két esetben az áthallást: gerjesztési oldalon az 561nm-es lézerrel az $\boldsymbol{A F 6} 4 \mathbf{7}$ is gerjeszthetö, míg az $\boldsymbol{A} \mathbf{F 5 6 8}$ emissziós spektruma átfedésben van az $\boldsymbol{A} \mathbf{F 6} \mathbf{4} 7$ emissziós spektrumával. De mi a helyzet az $\boldsymbol{A} \mathbf{F 5 6 8 - 6 4 7 n m}$ esetnél? (a relatív intenzitás $<0,02 \%$ ).

Fluoreszcencia élettartam mérés - Fluoreszcens festékeket azonban nem csak spektrumaik alapján lehet külön választani. Visszatekintve a 2.2. képletre lehetőség van élettartam $\left(\tau_{f}\right)$ alapján is különválasztani a fluorofórokat, és akár tíz feletti számban megkülönböztetni, még ha spektrálisan át is fednek [13]. A fluoreszcencia élettartam méréséhez (FLIM) használható mikroszkóp annyiban különbözik egy hagyományos fluoreszcens mikroszkóptól, hogy a gerjesztő fényforrás és a detektor is fel van készítve az időbontott mérésekre. Bár mindkét korábban tárgyalt képalkotási módra megvalósítható, csak a 
disszertációm szempontjából fontos pásztázási módot tárgyalom a továbbiakban.

Egy CLSM rendszerben a gerjeszési oldalon a lézereket rövid impulzushosszú, pico $10^{-12}$ - femto $10^{-15}$ szekundumos forrásokra kell cserélni, amik gyors ismétlési frekvenciával rendelkeznek $40-80 \mathrm{MHz}$. A másik módosítást a detektor oldalon kell megtenni, ugyanis lehetővé kell tenni nanoszekundum alatti felbontással a foton érkezési idők meghatározását. Ehhez az érzékelőt egy foton-lavina detektorra, vagy egy hibrid fotoelektron sokszorozóra kell cserélni. A jelfeldolgozást egy gyors elektronikára kell bízni. Az így kapott rendszerben már megvalósítható az idő-korrelált egyfoton számolás, a TCSPC [9].

A mérési módban a fluoreszcens molekulákat pillanatszerűen kell gerjeszteni, és mérni azt az időt, amikor az első emittált foton visszaérkezik a mintából. Egy adott területre többször megismételve a gerjesztés-detektálás lépést és az érkezési időket ábrázolva megkapható a foton kibocsátás valószínüségi eloszlása, vagyis a fluoreszcencia élettartam görbéje [13]. Illesztés után megkapható a keresett élettartam, vagy élettartam komponens többszörös exponenciális esetén.

A mért élettartam csökkenése több olyan jelenségre is utalhat, amikor a gerjesztett fluorofór egy nem sugárzó utat talál a relaxációra. A gerjesztett állapot többlet energiájától megszabadulhat az oldószeren keresztül, esetleg átadhatja azt egy szomszédos, $<10 \mathrm{~nm}$ távolságra lévő molekulának. Ezt az utóbbi jelenséget hívjuk Förster-rezonáns energia transzfernek (FRET), amely a donor és az akceptor fluorofór között jöhet létre, ha azok emissziós és abszorpciós spektrumai megfelelően átfednek [33]. Mivel a donor élettartamának csökkenéséből a lokális környezetben uralkodó távolságokra lehet következtetni, ez volt az első olyan nem optikai módszer, amivel biokompatibilis módon lehetett feloldás alatti távolságokat mérni fluoreszcenciával.

\subsection{Feloldási határ}

Egy optikai leképző rendszer feloldóképességet az egyes optikai elemek által bevezetett aberráció és a fény hullámtermészete korlátozza. A fellépő diffrakció miatt a pontforrás képe nem pont lesz, hanem egy kiterjedt folt, az Airy-féle elhajlási kép. A diffrakciós elmélet alapján az intenzitáseloszlás a 2.4 képlet alapján számolható ki, ahol $\Theta$ a megfigyelés félszöge, $I_{0}$ a maximális intenzitás, $J_{1}$ az elsőrendű Bessel-függvény, $k$ a hullámszám, $R$ a 
belépő apertúra sugara.

$$
I(\Theta)=I_{0}\left(\frac{J_{1}(k \cdot R \cdot \sin \Theta)}{k \cdot R \cdot \sin \Theta}\right)^{2}
$$

Ez lesz az optikai rendszer pontátviteli függvénye (PSF), amely további információkat is tartalmaz a rendszerben lévő aberrációk jeleire (mellékmaximumok és a maximum intenzitásának aránya, mennyire szimmetrikus, ...), mérete és felépítése pedig megadja a rendszer feloldóképességét. Mikroszkópiában ez egy pontszerü forrás diffrakciólimitált képének felel meg. Ernst Abbé 1873-ban megadta azt a feloldható minimális távolságot $d_{m i n}$, amit a fény hullámhosszából $\lambda$ és az első leképző elem által begyưjthető fény félnyílásszögének $\alpha$ szinuszából lehet kiszámolni. A 2.5. képlet mutatja ezt az összefüggést az $n$ törésmutatóval és a feloldási kritérium által megadott $k$ konstanssal kiegészítve. A Rayleigh-féle feloldási kritérium szerint az emberi szem két közeli pontot akkor tud még megkülönböztetni, ha az egyik pont elhajlási képének maximuma a másik pont elhajlási képének első minimumába esik. Ezen kritérium szerint a konstansot $k=0,61$-nek kell választani.

$$
d_{\min }=k \cdot \frac{\lambda}{n \sin \alpha}
$$

Létezik más feloldási kritérium is ( $k_{\text {Sparrow }}=0,47, k_{A b b e ́}=0,5$ ). A Sparrow-kritérium használható olyan esetekre is, amikor a zaj miatt az első minimumhely nem értelmezhető. Ugyancsak zajos esetekre használható W. V. Huston által javasolt, a PSF félérték szélességére alapozott kritérium is [34]. Ez utóbbi szerint látható tartományban $\sim 200 \mathrm{~nm}$ tekinthető a laterális feloldási határnak egy aberrációktól mentes optikai rendszerben. Axiális esetben ez az érték közel háromszor rosszabb, és a 2.6 képlettel számolható ki.

$$
z_{\min }=\frac{\lambda}{n \sin ^{2} \alpha}
$$

A diffrakciós határ közelében lévő optikai rendszerek esetén a PSF minősítésére használható a Strehl-arány [35, 36]. Ilyen esetekben ugyanis az aberráció kis növekedése nem a PSF méretét növeli meg, hanem annak intenzitás eloszlását befolyásolja. Az arány megmutatja, hogy a kapott PSF maximum intenzitása hányad része az ideálisan elérhető értéknek. A diffrakció limitált leképzésnek megfelelő Strehl-arány $\geq 0,8$.

A feloldási kritérium 2.5. képletéből látható, hogy a feloldás növeléséhez két lehetséges 
út van. Az egyik, hogy megnöveljük a leképző rendszer által begyüjthető sugarak szögét (pl. nagy numerikus apertúrájú olaj immerziós objektívet használunk). A képletből kiderül, hogy az immerziós olajak $n=1,51$ törésmutatójával számolva az elméletileg lehetséges maximális $\sin \alpha=1$ szög esetén a maximális tárgyoldali numerikus apertúra 1,51 [37]. Ez az érték a gyakorlatban a fedőlemeztől távol 1,39-re csökken, mert az ennél nagyobb törési szöggel rendelkező sugarak már nem gyüjthetőek össze a biológiai mintákra jellemző víz-üveg határon a teljes visszaverődés miatt. A fedőlemez közelében a fennmaradó rész kihasználható gerjesztés oldalon TIRF típusú mérésekhez, illetve ennek emissziós oldali megfelelöje a SAF [38] effektus jelentkezik.

A 2.5. képletből következtetett másik út a hullámhossz csökkentése. Látható tartományból ekkor már az UV tartományba szükséges lépni. Ez azonban problémát jelent, ahogy az az előző fejezetben is említésre került, bizonyos molekulák fluoreszcenciája felerősödik, és az autofluoreszcens háttér miatt csökken a kontraszt. Megoldás a technika váltása és elektronmikroszkóp használata. Itt ugyanis már nem a fény hullámhosszával kell számolni, hanem az elektron de Broglie hullámhosszával, ami az elektron sebességének függvénye. Ennek az iránynak azonban van egy hatalmas hátránya, a vizsgálandó minta kezelése ugyanis igen bonyolulttá válik, mert azt az előkészítés során vezetővé kell tenni, és a vizsgálathoz vákuumba kell helyezni. Sok biológiai minta és biológiai probléma nem alkalmas elektronmikroszkópos vizsgálatra.

Klasszikus optikai módszereket szem előtt tartva a rendszer által szabott határt nem léphetjük át, viszont megkerülhetővé tehető egy-egy új megközelítéssel. Azok a trükkök, amelyek csak a fény tulajdonságaira építenek a feloldást egy konstans szorzóval tudják csökkenteni és egy új határba ütköznek [34]. Ezeket a technikákat a 2.2. táblázatban foglaltam össze a teljesség igénye nélkül.

\subsection{Szuperrezolóciós technikák}

Azokat az optikai mikroszkópos technikákat, amelyek lehetővé teszik a feloldási küszöb alatti feloldás elérését nemcsak az elektromágneses tér, hanem fluorofórok fotofizikai és fotokémiai tulajdonságainak kihasználásával is, közös gyüjtőnéven szuperrezolúciós mikroszkópos technikáknak hívjuk. Az egyes megvalósítások annyiban térnek el egymástól, hogy más-más trükköt alkalmaznak a feloldási határ megkerülésére. 


\begin{tabular}{|c|c|c|}
\hline Technika neve & Feloldás javulása & Optikai trükk \\
\hline Confocal LSM[13, 39] & $\sim 1,4$ & $\begin{array}{l}\text { A detektor elött egy tűlyuk segítségével ki- } \\
\text { szűrésre kerül a fókuszon kívüli jel. }\end{array}$ \\
\hline TIRF [40, 41, 42] & csak z irányban & $\begin{array}{l}\text { A fedőlemez-minta határon létrejövő evan- } \\
\text { eszcens tér a minta egy }<\lambda \text { vastagságú réte- } \\
\text { gét világítja ki. }\end{array}$ \\
\hline ISM [43, 44] & $\sqrt{2}$ & $\begin{array}{l}\text { Tülyuk nélküli konfokális mikroszkópban a } \\
\text { keletkező kép egy kamera felületén jön lét- } \\
\text { re. A kis pixelméret miatt a térbeli feloldás } \\
\text { olyan, mintha nulla-méretü tülyuk lenne a } \\
\text { rendszerben. Az egyes pásztázási lépések he- } \\
\text { lyes összeadásával érhető el a feloldás növe- } \\
\text { kedés. }\end{array}$ \\
\hline ISM-reScan [45, 44] & $\sqrt{2}$ & $\begin{array}{l}\text { Az ISM optikai megvalósítása. A konfokális } \\
\text { mikroszkópban a tűlyuk által megszürt jelet } \\
\text { a kamera felületére kétszeres pásztázó méret- } \\
\text { tel visszavetítve az effektív foltméret lecsök- } \\
\text { ken. }\end{array}$ \\
\hline $\operatorname{SIM}[46]$ & 2 & $\begin{array}{l}\text { Ismert mintázatú gerjesztéssel és annak elfor- } \\
\text { gatásával kétszeres effektív numerikus aper- } \\
\text { túrát lehet kapni (Moire-effektus). }\end{array}$ \\
\hline CSIM[47] & 4 & $\begin{array}{l}\text { A minta oldalon létrehozva a struktúrát plaz- } \\
\text { monikus struktúrával, elméletileg négysze- } \\
\text { res feloldásnövekedés érhető el. }\end{array}$ \\
\hline $4 \mathrm{Pi}[48]$ & csak z irányban & $\begin{array}{l}\text { a szembe fordított két objektív közötti tér- } \\
\text { fogatban a gerjesztő lézer állóhullámot hoz } \\
\text { létre }\end{array}$ \\
\hline $\operatorname{InM}[49]$ & csak z irányban & konstruktív interferencia \\
\hline
\end{tabular}

2.2. táblázat. A csak optikai trükköket alkalmazó feloldásjavító technikák maximálisan egy kettes faktort (elméletileg egy négyest) tudnak javítani az elérhető laterális feloldáson.

Az általam választott definíció a szuperrezolúcióra egy szigorúbb definíció, emiatt is kerülhetett pár szuperrezolúciósnak nevezett technika „visszafokozásra” a 2.2 , táblázatba. Ebben az alfejezetben a teljesség igénye nélkül bemutatom a főbb technikákat, és bár betűszavakból sosem lehet hiány, az olvasóra bízom a többi feloldását pár kiváló áttekintő cikket [50, 51, 52], valamint meggyőző példákat [53] javasolva. 


\subsubsection{Pásztázáson alapuló szuperrezolúciós technikák}

Az első szuperrezolúciós trükk a fotofizikára épít és a kényszerített emissziót használja ki. Innen jön a szuperrezolúciós technika neve is: STimulated Emission Depletion, STED. Alapötlete 1994-ben került publikálásra [54]. Feltalálása és megvalósítása Stefan W. Hell nevéhez füződik, amiért 2014-ben megosztott kémiai Nobel-díjat kapott. A mikroszkóp felépítése alapjaiban megegyezik a 2.3.a ábrán látható konfokális elrendezéssel. Amiben eltér az az, hogy a mintát egy további lézernyaláb világítja ki. Ez a STED nyaláb fázis manipulált, alakja a fókuszsíkban egy fánkra hasonlít. Hullámhossza nagyobb, mint a fluorofór emissziós spektrumának központi hullámhossza. Ez kényszerített emissziót vált ki a gerjesztett állapotban lévő fluorofórokból a STED nyaláb hullámhosszán, amit optikai szűrőkkel ki lehet szürni a mintából érkező jelből. Mivel a stimulált emisszió hatáskeresztmetszete alacsony, ezért az a fánk közepén csak nagyon kis valószínűséggel fog bekövetkezni. Bár a fluorofór képe továbbra is diffrakció limitált lesz, de mivel ismert a fánk középpontja, ahonnan a fluoreszcencia jel származhatott, ezért megmondható annak feloldás alatti pozíciója. A technikában a laterális feloldás a 2.7. képlettel közelíthető, ami hasonlít a 2.5. képlethez, annyi különbséggel, hogy megjelenik egy STED nyaláb intenzitásától $I_{\text {max }}$ függő tag. Az $I_{s}$ a fluorofórra jellemző szaturációs teljesítmény, ami a spontán emisszió élettartamából és a hatáskeresztmetszetből számolható [55].

$$
d_{\text {min }}=0,5 \cdot \frac{\lambda}{n \sin \alpha \cdot \sqrt{1+I_{\max } / I_{s}}}
$$

A feloldás növeléséhez tehát elegendő a STED nyaláb intenzitását növelni $I_{\max } / I_{s} \rightarrow \inf$, hogy lecsökkenjen az a térfogat a fánkon belül, amiben még a fluorofórok gerjesztett állapotban vannak. Ebből lehet következtetni a technika hátrányára is, mert a $\sim 10 \mathrm{MW} / \mathrm{cm}^{2}$ teljesítményü megvilágítás mellett a második-harmadik pásztázást már kevés fluorofór éli meg. A lehetséges modalitások közül a 3D-t említeném meg, amely során a STED nyalábba egy olyan módosítás kerül bevezetésre, amely eredményeként a fánk mellett, a fókuszsík alatt és felett is kialakul egy-egy STED folt. Ez által az axiális irányú felbontás 100 nm-re csökkenthető [56].

Egy másik pásztázáson alapuló szuperrezolúciós technika a 2017-ben publikált Minflux [57], ami ugyancsak Stefan W. Hell nevéhez füződik. Két együttesen alkalmazott 
trükk segítségével nanométer közeli feloldás érhető el. Az első, hogy a pásztázó nyaláb (a korábban említett STED nyalábhoz hasonlóan) fánk alakú. A pásztázott mintázat egy egységnyi területen belül négy pontot tartalmaz: egy pont körül további három $120^{\circ}$-ra egymástól egy köríven. A felvett fluoreszcencia intenzitásokat interpolálva és annak a minimumát keresve meghatározható a fluorofór helye a mintázaton belül. Ez természetesen csak egy fluorofór esetén működik. Hogy többet is meg lehessen különböztetni egy másik trükköt is be kell vetni, mégpedig azt, hogy bizonyos fluorofórok ki-be kapcsolható fluoreszcenciával rendelkeznek. (Erről a második trükkről részletesebben a következő alfejezetben beszélek.) A feloldás a három külső pontra húzható kör kerületének méretével hangolható, és kiterjeszthető 3D-re is a képalkotás [58]. Sajnos a pásztázási mód a technika jelenlegi állapotában azt eredményezi, hogy csak egy kis területen érhető el nagy feloldás.

\subsubsection{Széleslátóterü, lokalizáción alapuló szuperrezolúciós technikák}

Visszatérve a feloldási küszöb problémájához észrevehető az, hogy a bonyodalom a két pont közelségéből fakad, ezért válnak feloldhatatlanná. A feloldási kritérium nem akadályoz meg abban, hogy egyetlen fluorofór helyét nanométer precizitásra és pontosságra meghatározzuk [59], vagy mozgását kövessük [60, 61]. Ha egy sűrűn megjelölt minta esetén az egyes fluorofórokat külön-külön lehetne leképezni, akkor a feloldási határ egy csapásra megszünne, hiszen nincs, ami átfedjen. Széleslátóterü mikroszkópra több olyan feloldásjavító megközelítés került leírásra és megvalósításra az elmúlt évtizedben, amelyek valamilyen módon a fluoreszcencia állapotok közötti kapcsolási trükköket használják ki. Megfelelő körülményeket megteremtve így elérhetővé válhat az, hogy a kapcsolási események időben és térben elkülönülve ne fedjenek át, ez által megőrizve a megkülönböztethetőséget. Az így kapott eredmények sokszor lenyügözőek [53].

A fotoaktiválható lokalizációs mikroszkópia (PALM[62], FPALM[63]) olyan fluoreszcens fehérjékre múködik, amelyek alap állapotban kikapcsolt, nem fluoreszcens állapotban vannak. Eric Betzig 2014-ben a technikáért megosztott kémiai Nobel díjat kapott. A felvétel elkészítéséhez a mérést ciklikusan kell végezni. Az első lépés megegyezik egy normális mikroszkópos felvétellel. A fotoaktiválható fehérjéket tartalmazó mintát gerjeszteni kell (például 561 nm-es lézerrel), és addig készíteni videót az elszórtan aktív állapotban lévő 
fehérjékről, amíg azok száma egy küszöbérték alá nem csökken. A folyamatos megvilágítás során az aktív fehérjék kiégnek, ezért csökken a számuk. A következő lépésben alacsony hullámhosszú ( 405 nm) fénnyel impulzus szerüen meg kell világítani a mintát, ami hatására a fehérjék egy része aktiválódik, cisz-transz konformáció változáson esnek át. Elegendően alacsonyra választva az aktiváló lézer teljesítményét az inaktív populáció egy alacsony hányada válik csak aktívvá, és a ciklus kezdhető elölről. Ideális esetben a fotoaktiválható fehérjék nem kapcsolhatóak önállóan, így az is megmondható, hogy egy adott területen hány fehérje kerül kiolvasásra [62]. GFP mutánsok esetén megfigyelhető nagy lézerteljesítmény mellett $\left(\sim 2 k W / \mathrm{cm}^{2}\right)$ (és aktiváló lézer nélkül is) egy olyan, egyedi molekulákra jellemző ciklikus viselkedés is, amit egy rövid fluoreszcens állapot (ON állapot), és egy valamennyivel hosszabb sötét állapot (OFF állapot) jellemez [64].

A GSDIM[65] (alap állapot kiürítéses képalkotó mikroszkópia) a foszforeszcenciát használja ki. Az $S_{0}$ alap állapot kiüríthető úgy, hogy a gerjesztés során a triplett állapotba juttatjuk a fluoreszcens festékeket, ez által kikapcsoljuk annak élettartamára. Mivel ennek a belső átmenetnek a valószínűsége (hatáskeresztmetszete) alacsony, ezért a gerjesztő lézerteljesítmény megnövelésével az $S_{1}$ populációja is megnövekszik és így a $T_{1}$ állapotba is több juthat át belső konverzióval. Ha elegendően nagy a lézerteljesítmény $\left(\geq 1 \mathrm{~kW} / \mathrm{cm}^{2}\right)$, akkor több molekula ragad a hosszú élettartamú triplett állapotban, mint amennyi visszatérhet alap állapotba, így azok megkülönböztethetőek lesznek. A triplett állapot szerepét $\beta$-merkaptoetanollal (egy triplett kioltóval) lehet meggátolni, amely mennyiségének növelésével bizonyítható a trükk fotofizikai háttere [66]. A technika rhodamine típusú szerves festékekre és fluoreszcens fehérjékre is működik, amennyiben azok elég fotostabilak.

A STORM[67] és a dSTORM[68] (sztochasztikus optikai rekonstrukciós mikroszkópia) technika trükkje a fotokémiára, bizonyos szerves fluoreszcens festékek kapcsolhatóságára épít. A direkt verzió csak annyiban különbözik, hogy nem használ egy második, kisebb hullámhosszon gerjeszthető festéket a visszakapcsoláshoz. Cián típusú festékek esetén (például Cy5) 1kW/ $\mathrm{cm}^{2}$ lézerteljesítmény esetén megfigyelhető egy aktív állapotból történő kapcsolás hosszú sötét állapotba. A kikapcsolt állapotból véletlenszerüen tér vissza alap állapotba, és erre a folyamatra a gerjesztőnél alacsonyabb hullámhosszú lézerrel rá lehet segíteni $(\sim 300 \mathrm{~nm}-532 \mathrm{~nm})$ [69]. Ehhez a viselkedéshez egy olyan oldatra, „switching buffer"-re is szükség van ami triplett kvencsert ( $\beta$-merkaptoetanolt vagy merkaptoetila- 
mint), valamint egy glükózoxidáz alapú oxigén elvonó rendszert is tartalmaz [70, 71]. A használatos festékek közül a legjobb eredményeket a vörös tartományban gerjeszthetőekkel és cián szerkezetűekkel lehet elérni. A legelterjedtebb ilyen festék az AF647, amely a szinte tökéletes kapcsolási tulajdonságokkal és jó fotostabilitással rendelkezik [72]. Azonban azt is meg kell jegyezni, hogy a pontos kapcsolási mechanizmus nem ismert [73]. A GSDIM és a dSTORM technika között nehéz éles határt húzni.

Egy kicsit kakukktojás a PAINT[74] technika, mivel nem a festékkel trükközik, hanem annak mintához való kötési idejével. A trükk lényege, hogy ameddig a festékmolekulák szabadon úszkálnak a mintát körülvevő oldatban, addig csak a hátteret emelik. Amint hozzákötnek a mintához, akkor egy egyértelmü pontforrás jelenik meg, ami itt a bekapcsolt állapotot jelenti. Egy bizonyos idő után a festék kiég, vagy elválik a mintától és újra szabadon mozog, tehát a detektor szempontjából kikapcsol. DNA-PAINT[75] esetében a kötési időt egyszálú DNS láncok nukleinsav számával lehet szabályozni.

A fentebb bemutatott mérési technikákkal készült felvételsorozatok feldolgozása, amelyek egyes képkockáin a bekapcsolt (ON) állapotú molekulák képei láthatóak, ezek után már hasonló módon történik. Az egyes kapcsolási eseményeket, amikről az a feltételezés, hogy csak egy aktív fuorofórtól származó fotonokat tartalmaznak, meg kell keresni a képkockákon. Ki kell használni azt az előzetes tudást, hogy a keresett molekula helyére a legjobb közelítés az Airy-féle elhajlási kép közepe. A rendszer pontátviteli függvényével illesztve az egyes eseményeket, azok maximumának xy pozíciója megkapható a pixelen belül [76]. A PSF alakját több tényező is befolyásolhatja, így ezeket figyelembe véve és a számítási igény alacsonyan tartása miatt az Airy-függvény helyett a Gauss-függvény is használható [77]. Az illesztés történhet a legkisebb négyzetek módszerével vagy maximum likelihood becsléssel [78]. Összegyüjtve a maximumhelyek koordinátáit egy eseménylistába, majd az előre meghatározott szűrési paramétereknek megfelelőket felhasználva a kép előállítható pointillista módon [79]. A 2.5. ábrán ennek a feldolgozásnak a folyamata látható [53]. A feldolgozást elvégző szoftvereket lokalizációs algoritmusoknak hívjuk, és a disszertáció írásakor 95 darab mérette meg magát az SMLM szoftverek versenyén [80], köztük a sajátunk is [81][S4].

Az olvasóban felmerülhet az a kérdés, hogy ha ennyi szoftver készült nagyjából ugyan- 



2.5. ábra. Az $\boldsymbol{S M L M}$ technikák képalkotása. Az (a) ábrán a bekapcsolt állapotban lévő fluorofór pixelizált képe látható. Erre az alulmintavételezett $\boldsymbol{P S F}$-re Gauss-függvényt illesztve (b) megkapható annak maximumhelye (c). Egy adott területröl (e-g) összegyüjtve a kapcsolási eseményeket pointillista módon megkapható a végső kép (h). Átvett ábra [53], módosításokkal. Az (e) ábrán a skála 5 mikront jelöl, a (d) a kiemelésekhez kapcsolódóan 1 mikront.

annak a problémának a megoldásárat] akkor mégis hogyan válasszunk közülük [82] Melyik által készített képet fogadjuk el? Hogyan adható meg egy ily módon készült képen a feloldás?

\subsection{Feloldás értelmezése az SMLM technikákban}

Az egyedi események lokalizációs precizitását a detektált fotonok száma határozza meg. A detektált fotonok számának növelésével javul a Gauss-görbe illesztési precizitása. Olyan fluorofórt (és mikrokörnyezetet) kell tehát választani, ami egy kapcsolási ciklus alatt több ezer fotont emittál. A detektor expozíciós idejét a bekapcsolt állapot várható hosszához kell igazítani. Valamint a detektor pixelméretét elegendően nagyra kell választani ahhoz, hogy illeszthető legyen rá egy a PSF-hez hasonló függvény, de kellően kicsire is ahhoz, hogy a fotonszám megfelelő legyen. Gauss eloszlás esetén a lokalizáció bizonytalansága az előbbieket összefoglalva a 2.8 képlettel, a Thompson-képlettel adható meg CCD detektor

\footnotetext{
${ }^{1}$ Egy kis önkritikát megengedve az alábbi képpel magyaráznám a problémát: https : //xkcd.com/927/
} 
esetén [83].

$$
<(\Delta x)^{2}>=\frac{s^{2}+a^{2} / 12}{N}+\frac{8 \pi s^{2} b^{2}}{a^{2} N^{2}}
$$

Ahol $s$ a detektált fotoneloszlás méretének fele, $a$ a pixelméret, $N$ a detektált fotonok száma, $b$ a háttet jellemző faktor. Ha eltekintünk a háttér tagtól és a pixelizálás hatásától, akkor a 2.8 képletet a 2.9 közelítésre egyszerüsíthetjük [62].

$$
\Delta x \approx \frac{s}{\sqrt{N}}
$$

Lokalizáció során a festék vagy fluoreszcens molekula koordinátáját határozzuk meg. Az epitóp valódi helye azonban nem feltétlenül ott van, ahol a festéket detektálni tudjuk. Immunfestés esetén ez nem egyezik meg az epitóp koordinátájával az antitestek mérete miatt. Ezt tovább gondolva kikövetkeztethető az, hogy hiába javítjuk a lokalizációs precizitást, végső soron a koordinátameghatározás pontosságát a használt antitest vagy linker mérete fogja behatárolni [84]. Így ezek méretének csökkentésére folynak most törekvések [85]. Az irodalomban további értékmérőkkel is lehet találkozni:

Mortensen-képlet. A Thomspon-képlethez hasonlóan az egyedi fluorofórok koordinátamegtatározásának precizitásáról szolgáltat információt. Annyi módosítást tartalmaz, hogy figyelembe veszi a detektor elektron sokszorozó réteg zajának várható értékét is [86].

Cramér-Rao alsó határ. Megadja azt a legjobb lokalizációs precizitást, amit elméletileg a mérés paraméterei szerint megkaphatunk [87].

Eddig az egyedi kapcsolási események lokalizációs precizitásáról és pontosságáról volt szó. Felmerül azonban a kérdés, hogy mintára vonatkoztatva hogyan lehet kiadni egy számot, ami végső soron megadja a feloldást. Ha vesszük az egyes lokalizációkat és azoknak képezzük a konvolúcióját a helymeghatározásuk pontosságával (Gauss-függvény), akkor egy hasonló kép kapható, mintha a diffrakciólimitált leképzés során a PSF-el vettük volna a konvolúciót. Alkalmazva erre az új képre a feloldási-kritérium képletét a Sparrow küszöbbel, akkor megkapható az a minimális távolság, ami még megkülönböztethető a lokalizációból származó képen. Így adható egy vak becslés $\left(\hat{d}_{S T L}\right)$ a lokalizációs precizitások $\Delta x$ alapján a feloldási küszöbre a 2.10, képlettel [88] : 


$$
\hat{d}_{S T L}=2 \cdot \sqrt{\sum_{i}^{n}\left\langle\left(\Delta x_{i}\right)^{2}\right\rangle}
$$

A disszertációmban az új eredmények bemutatásánál ezt a képletet fogom használni, ha a mintára számított feloldásról beszélek.

\subsection{Modalitások az SMLM technikákban}

Az alap SMLM technikában a mintából kinyerhető információ a fluorofórok xy koordinátája, a felvillanási események intenzitása és időbeli hossza, valamint a pontátviteli függvény mérete a detektoron. Rekonstrukció során ezekből az adatokból egy kétdimenziós kép készíthető el. Ha egyéb információra (z koordináta, dipólorientáció, spektrális tulajdonságok, ...) is kíváncsiak vagyunk akkor további trükköket és megoldásokat kell bevetni. Ennek eléréséhez a rendszer pontátviteli függvényének módosítására lehet szükség. A bevezetett módosítások ismeretében kinyerhető a plusz információ jellemzően az elérhető feloldás romlásának árán. Sok megoldás kis módosításokkal átültethető az SMLM technikára, amit már korábban a tracking problémákra alkalmaztak. A fejezetben több ilyen modalitást veszek górcső alá.

\subsection{1. $3 \mathrm{D}$}

Indirekt módon a felvillanási esemény $\mathbf{z}$ koordinátája egyértelmüen nem, vagy csak nehezen határozható meg a hibátlan PSF laterális méretéből. Ha a kísérlet során nem lép fel komplikáció, például törésmutató változásból fakadó szférikus hiba, akkor a fluorofór PSF-je a fókuszsík alatt és felett szimmetrikusnak tekinthető [84]. Olyan módosítást kell bevezetni az optikai rendszerbe, ami ezt a szimmetriát elrontja, és így meghatározhatóvá válhat a 3D koordináta. Négy elterjedt módszert ismertetek.

Asztigmatizmus - Egy nagy fókusztávolságú hengerlencsével egyszerúen módosítható a PSF a detektor karban [89]. Ilyenkor az optikai leképző rendszerbe asztigmatizmus kerül bevezetésre, és a fókuszsík különböző lesz az optikai tengely mentén x és y irányban. Ez azt eredményezi, hogy a fluorofór képe a detektoron nem szimmetrikus, hanem elliptikus lesz. Az alakja és az iránya a flurofór z koordinátájától fog függeni. A fókuszsík alatt 
a fluorofór képe y irányban elnyújtottabb lesz, mint $\mathbf{x}$ irányban, a fókuszsíkban azonos lesz a két tengely mérete, míg a fókuszsík fölött $\mathbf{x}$ irányban lesz nagyobb a mérete, mint y irányban [90]. Elforgatva 90-kal a lencsét, az irányok megfordulnak. A harmadik koordináta meghatározását tehát visszavezettük egy méretmeghatározás problémára. A 2.6 ábra mutatja azt az esetet, amikor a hengerlencse az objektív és a tubuslencse közé kerül. Ebben az esetben a bevezetett asztigmatizmus kevésbé hangolható [90]. Viszont abban az esetben, ha a tubuslencse és a detektor közé kerül a hengerlencse, annak detektortól mért távolságának változtatásával már hangolhatóvá tehető. A feloldható z intervallum mérete kis asztigmatizmus esetén a legnagyobb, ilyenkor viszont a z koordináta feloldása rossz. Nagy asztigmatizmus bevezetésével kis vastagságban sokkal precízebben határozható meg a harmadik koordináta.

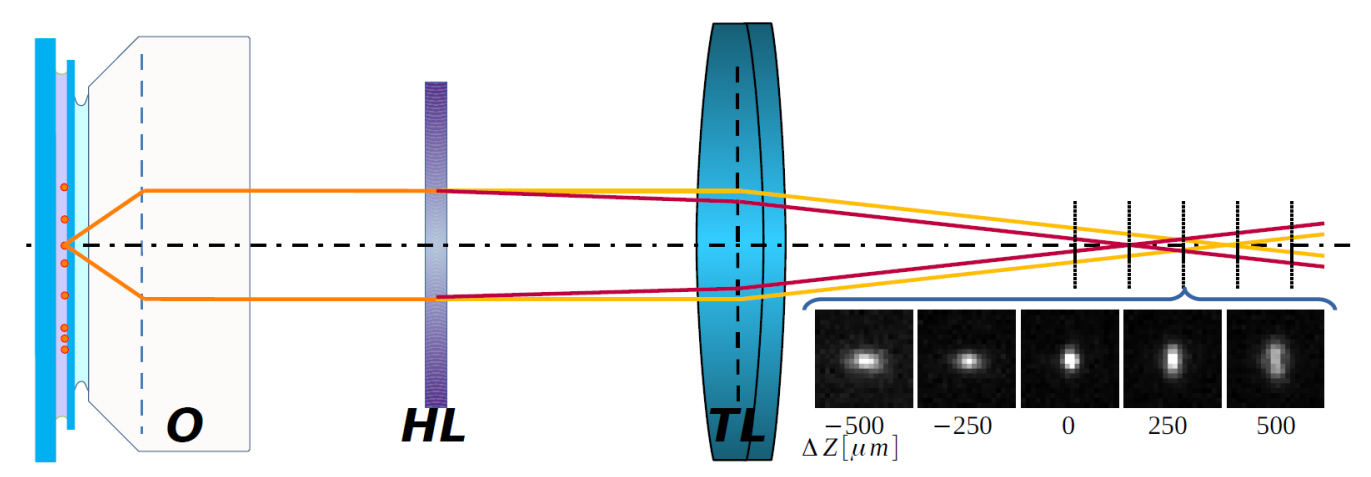

2.6. ábra. A hengerlencsét az optikai útba helyezve asztigmia vezethetö be. A fluorofór képének alakja így a fókuszsiktól mért távolságtól fog függeni.

A lokalizáló algoritmusban külön kezelve és illesztve a Gauss-függvény $W_{x}$ és $W_{y}$ méretét, minden egyes felvillanáshoz kiszámolható az ellipszis alakja. Egy kalibrációs táblázatra (vagy egy kalibrációs függvényre) is szükség van, amely tartalmazza az adott optikai elrendezésben az ellipszis alakokat és a hozzájuk rendelhető z koordinátákat. Az adatfeldolgozás során így a mérési adatokhoz hozzárendelhetővé válik a mélységi információ. A z koordináta meghatározásának precizitása azonban nem állandó. A feloldható z tartomány szélein a rá illesztett Gauss-függvény pontatlan lesz az egyik tengely nagy de-fókuszáltsága miatt.

A modalitás alkalmazásának előnye az, hogy az optikai leképzőrendszer egy egyszerü módosítását igényel csak. Hátránya viszont az, hogy a teljes mélységélességben egyszer 
sincs mindkét tengelyen fókuszban a fluorofór. Az így kapott xy koordináták is pontatlanabbak lesznek, és ez által az elérhető feloldás lecsökken.

Kétsíkú leképezés • Egy másik lehetséges PSF módosítás a 3D információ kinyeréséhez a kétsíkú leképezés (angol nevén bi-plane). Ennek a modalitásnak a megvalósításához egy 50/50 nyalábosztót kell a detektor karba helyezni, és úthossz különbséget bevezetni az így létrejövő két kar között. Ugynarról a fluorofórról így két eltérő fókuszsíkban keletkezik egy-egy kép. A fókuszsík alatt a fluorofór képe a detektor A oldalán létrejövő képen lesz éles, míg a B oldalon de-fókuszált. A fókuszsíkban azonos méretűek, míg a fókuszsík felett a detektor B oldalán létrejövő kép lesz éles, és az A oldalon lévő de-fókuszált [91. A 2.7. ábra mutatja az elrendezést és a különböző síkokban létrejövő képeket a detektoron. A kettéválasztott fókuszsíkok közötti távolságot a nyalábosztó után bevezetett úthossz különbséggel lehet hangolni [92].

A lokalizációs algoritmusnak szimmetrikus Gauss-függvényt kell illesztenie ezen modalitás alkalmazásakor az egyes felvillanások képeire, ami az alakmeghatározás precizitását is javítja. Az illesztésből kapott félérték szélességet $W_{A}$ vagy $W_{B}$ jelöléssel kell letárolni aszerint, hogy a detektor melyik oldalán (a két kép közül melyiken) történt a lokalizáció. Szükség van továbbá egy párkereső algoritmusra is, amely az egy időben felvillanó és a detektoron azonos távolságra lévő eseményeket újra összekapcsolja. Vegyük észre, hogy a kétsíkú leképezés modalitása visszavezethető egy már korábban tárgyalt és megoldott problémára, a 3D asztigmatizmus modalitásra. Csak el kell végezni a $W_{x}=W_{A}$ és a $W_{y}=W_{B}$ helyettesítést. A 2.7, ábra mutatja az illesztett PSF méreteket az eredeti fókuszsíktól mért távolság függvényében. Hasonlóan az asztigmatizmus modalitáshoz, itt is egy elöre elkészített kalibrációs táblázatból, kalibrációs függvényt használva kapható vissza a harmadik koordináta a PSF párok méretéből.

A modalitás alkalmazásának előnye, hogy nagyobb tartományon használható az asztigmatizmus modalitásnál. Hátránya viszont az, hogy a detektálható fotonszám eleve megfeleződik, és így a technika alkalmazása során elérhető feloldás a 2.9 közelítés alapján a $\sqrt{2}$ szeresére romlik ugyanazon körülmények mellett.

Dupla Hélix - A detektor kar Fourier-síkjába egy fázismaszkot kell behelyezni SLM (spatial light modulator) használatával. A maszk kialakítása olyan PSF módosítást ve- 


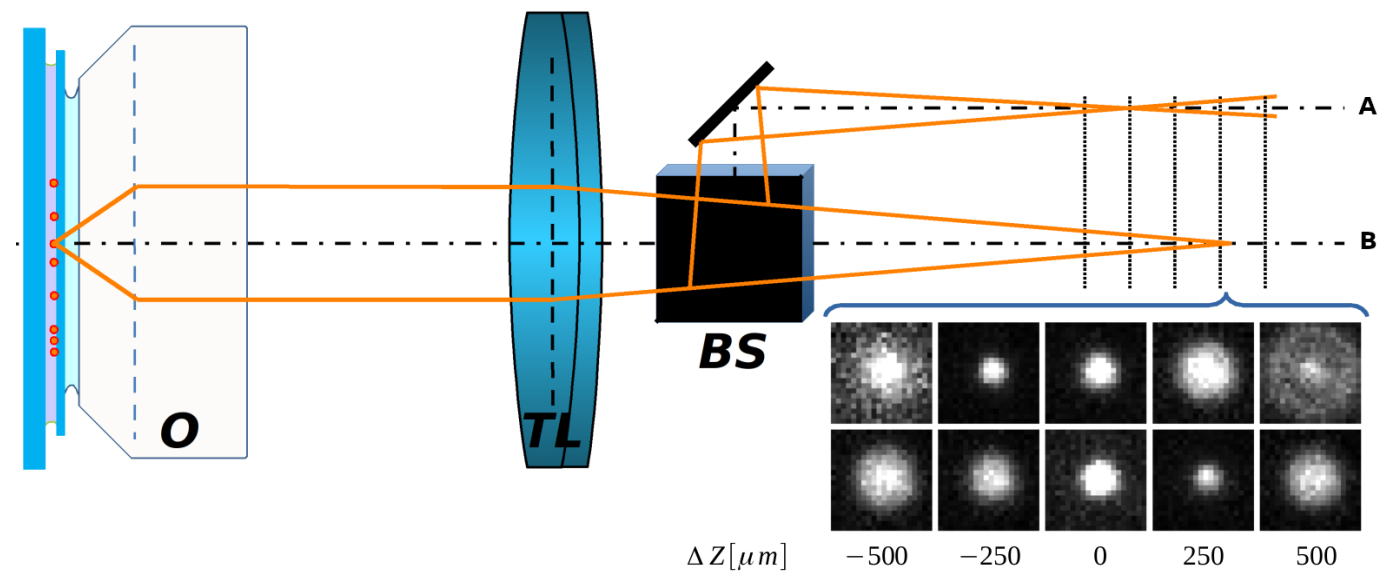

2.7. ábra. A begyüjtött fluoreszcencia egy nyalábosztó kockával ketté bontható a detektor karban, így vezetve be úthossz különbséget. Igy két különböző képsík jön létre.

zet be, amely hatására az két részre bomlik, és azok egymáshoz viszonyított orientációja a forrás z pozíciójától fog függeni [93]. Áthaladva a fókuszsíkon a detektoron lévő két folt egymáshoz képest elfordul. Ha ezt egy z projekcióval ábrázolnánk, akkor két csavarvonalat rajzolna ki [94]. A harmadik koordináta meghatározásának problémája tehát visszavezethető egy szög meghatározás problémára. A technika előnye, hogy a létrejövő két PSF mérete a teljes mélységélességben állandó és így a lokalizációs precizitása is, viszont használata a bi-plane esetnél is nagyobb fotonveszteséget okoz.

Fotometria • Ahogy abban a 3D technikák bevezetőjében is szó volt, indirekt módon nem határozható meg a PSF alakjából a harmadik koordináta, hacsak nem lép fel „komplikáció”. Az objektív fedőlemez korrekcióját szándékosan elrontva elérhető az, hogy a fókuszsík alatt és fölött a PSF aszimmetrikus legyen. Erre épít a fotometria [95] 3D technika, amely a PSF-en belüli radiális intenzitás eloszlási arányokból mondja meg a fluorofór z koordinátáját.

A SAF (Supercritical Angle Fluorescence) technika a TIRF emisszió oldali megfelelőjét használja ki [96]. Ha a fluorofórok fedőlemeztől mért távolsága kisebb mint a hullámhossz, akkor a teljes visszaverődés határszögénél nagyobb szögben érkező fotonok is begyűjtésre kerülnek [38]. A minta Fourier-síkjában ezek a fotonok az optikai tengelytől távolabb haladnak. Megvalósítás során az emissziós fényt egy nyalábosztóval ketté kell bontani, és egyik karban apertúrával ki kell maszkolni a nagy térszögekhez tartozó 
fotonokat. A fedőlemeztől mért távolság meghatározása ekkor egy intenzitás különbség mérésre vezethető vissza.

\subsubsection{Polarizáció és anizotrópia}

Értékes információ lehet a fluorofór emissziós dipólusának irányát meghatározni egy mérésből, amit például a fluorofór képének aszimmetriájából lehet megadni [97]. A technikában használt pixelméret és az expozíciós idő hosszúsága miatt erre nincs azonban direkt lehetőség. Egyik megoldás lehet a gerjesztő lézer manipulálása az emittált jel modulálására [98, míg más megoldások a PSF manipulációjára hagyatkoznak a detektor oldalon.

Ezen utóbbi irányon maradva bevezethető olyan PSF módosítás, ami polarizáció szerint bontja ketté a fluorofór képét a gerjesztő fény polarizációs tengelye szerint merőleges és párhuzamos komponensekre [99]. Ilyen optikai elem lehet a polarizációs nyalábosztó kocka, Wollaston-prizma [100] és a csapatunk által fejlesztett kettősen törő ék B3. Egy párkereső algoritmussal a kettébontott kép párokba rendezhető, és a problémát vissza lehet vezetni fotonszám mérésre. A fluorofór által a gerjesztő lézer polarizációjával bezárt szög expozíciós időre vett átlaga meghatározható a két folton mért intenzitás ( $I_{\|}$és $I_{\perp}$ arányából, amiből számolható még polarizáltság a 2.11. képlet alapján, vagy anizotrópia a 2.12, képlet alapján 9 .

$$
\begin{gathered}
P=\frac{I_{\|}-G \cdot I_{\perp}}{I_{\|}+G \cdot I_{\perp}} \\
r=\frac{I_{\|}-G \cdot I_{\perp}}{I_{\|}+2 G \cdot I_{\perp}}
\end{gathered}
$$

A pontos és precíz mérések megkövetelik a rendszerre jellemző két csatorna közti korrekció ( $G$-faktor) meghatározását mérés előtt. Az így kapott $P$ vagy $r$ értékből következtetni lehet a lokális viszkozitásra, vagy a fluorofórok kötésének erősségére is az általuk bezárt szög bizonytalanságára [100]. A modalitás alkalmazásának hátránya a bi-plane esethez hasonló, a nyalábosztás miatt a fotonszám az egyes polarizációs tengelyhez tartozó kapcsolási események képeiben lecsökken. Ez a lokalizációs precizitás romlását vonja maga után. 


\subsubsection{Spektrális bontás}

Az alacsony fotonszám miatt színes detektor használatára nincs lehetőség azok alacsony kvantumhatásfoka miatt. Ezért ha a fluorofórok emissziós spektrumáról szeretnénk információt gyüjteni, akkor két lehetőség adódik bonyolultság szerint. Az egyszerűbb eset, amikor a detektor karba egy további dikroikus tükröt (DM2) és emissziós szürőket helyezünk [101, 102] (2.8, ábra). Ezeket az optikai elemeket úgy választjuk ki a méréshez, hogy a használt emissziós ablakot a fö dikroikus tükrön kettébontsa. A detektoron egy festékhez két kép fog tartozni, hasonlóan a polarizációs modalitáshoz. A pár intenzitásának viszonya attól fog függeni, hogy az emissziós spektrumát a második dikroikus tükör milyen hullámhossznál bontja. A mintát két, azonos hullámhosszal gerjeszthető, de eltérő Stokes-eltolással rendelkező fluorofórral jelöljük. Párokba rendezve a kapott foltokat, azok intenzitásainak arányából és az irodalomból ismert emissziós görbékből megmondható az, hogy a felvillanás valószínúleg melyik fluorofór típushoz tartozott. Tehát a probléma újra vissza lett vezetve egy intenzitás mérésre. A technika előnye, hogy az optikai útban történő minimális módosítással azonos hullámhosszú gerjesztés mellett is megkülönböztethető két festék, a hátránya a lokalizációs precizitás romlása, mert az egyes foltokban a fotonszám lecsökken.

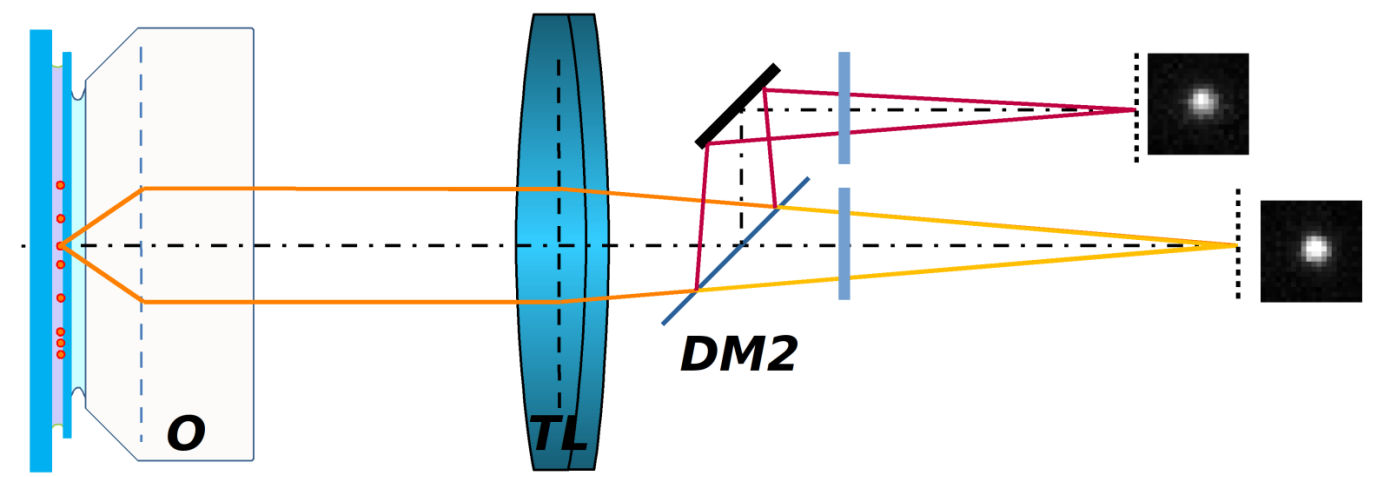

2.8. ábra. A detektor karban egy dikroikus tükörrel (DM2) és további emissziós szürőkkel a detektált emissziós jel két részre bontódik. A detektoron mért intenzitás arányokból megállapítható több különböző Stokes-eltolással rendelkező, de azonos hullámhosszal gerjesztett festék típusa.

Léteznek erre a problémára összetettebb megoldások is, amelyek bontóelemként egy diszperziós elemet használnak. Spektrális bontás vezethető be prizma használatával [103, 
104] vagy optikai rácsot használva [105]. Az utóbbi elemet behelyezve a kamera elé, az a fluorofór képét több rendre bontja, amelyek közül a nullad rendből nyerhető ki a kapcsolási esemény x-y koordinátája, míg az első rendből a spektrális információ. Prizma esetén a prizma előtt kell ketté bontani a detektor kar optikai útját, és csak az egyikbe bevezetni a diszperziós elemet. A probléma a párkeresés során visszavezethető egy távolság mérésre (központi hullámhossz meghatározása) és egy alul-mintavételezett emissziós spektrum illesztésére. Ezeknek az összetettebb megvalósításoknak az az előnyük, hogy több festéktípusra is múködik és valós színkódolás adható, hátránya viszont az elnyújtott spektrum miatti illesztési bizonytalanság megnövekedése.

\subsection{Modalitások összehasonlítása az SMLM technikákban}

Az eddig elmondott SMLM modalitások összehasonlítását az alábbi 2.3 , táblázatban foglaltam össze a teljesség igénye nélkül. A gyakorlati összehasonlítás amiatt nehéz, mert a fotonszám fluorofóronként és SMLM technikánként is változik, illetve a vizsgálandó mintánál sem lehet ugyanazokat a körülményeket biztosítani. Bár az egyes modalitás megvalósításoknál beszéltem az előnyökről és a hátrányokról, itt most adok egy becslést az elméleti lokalizációs precizitásra, azonos fotonszámot feltételezve, és a 2.9. képletet használva a 2D mérés alapján becsülve. A 2D felvételhez tartozó érték egy rendszerünkön készült tipikus dSTORM méréshez tartozó érték a a 2.10. képlet alapján számolva.

\begin{tabular}{|c|c|c|}
\hline Technika neve/Modalitás & Optikai elem & becsült elméleti precizitás \\
\hline \hline 2D SMLM & nincs & $\approx 25 \mathrm{~nm}$ \\
\hline 3D Asztigmatizmus[89, 90] & hengerlencse & $\approx 32 \mathrm{~nm}$ \\
\hline 3D Bi-plane[91, 99] & nyalábosztó kocka & $\approx 35 \mathrm{~nm}$ \\
\hline 3D Double Helix[93, 94] & fázislemez & $\approx 50 \mathrm{~nm}$ \\
\hline 3D Fotometria[95, 38] & semmi, vagy apertúra & $\approx 25-35 \mathrm{~nm}$ \\
\hline Polarizáció[99, [100] & nyalábosztó kocka & $\approx 35-50 \mathrm{~nm}$ \\
\hline Többszínú[101, 102] & optikai szüró & $\approx 30-35 \mathrm{~nm}$ \\
\hline Spektrális[103, 104, 105] & prizma, rács & $\approx 35-50 \mathrm{~nm}$ \\
\hline
\end{tabular}

2.3. táblázat. Mint az látható, ha az xy koordinátákon felül további információt szeretnénk kinyerni a mintából, ahhoz a legtöbb esetben fel kell áldozni a laterális lokalizációs precizitást, ami magával vonja az elérhető feloldás romlását is. A táblázat harmadik oszlopában található értékek a 2.9 képletet használva kerültek megbecsülésre egy tipikus 2D dSTORM mérés alapján. 
Adott a lehetőség a modalitások egyidejü alkalmazására is [106, 107]. Ehhez tovább kell osztani a mintából összegyưjtött fotonokat, ami magával vonja az elérhető lokalizációs precizitás és a feloldás romlását is. 


\section{Célkitüzés}

Az egymolekula detektáláson alapuló lokalizációs mikroszkópia egy fotonlimitált technika. Használata lehetőséget nyújt arra, hogy a feloldási határ problémáját megkerülve biokompatibilis módon vizsgáljunk struktúrákat $<25 \mathrm{~nm}$ laterális precizitással. Ahogy azt a bevezetőben is hangsúlyoztam, bármilyen torzulás a pontátviteli függvényben ezen a precizitáson és a pontosságon rontani fog. Számos gyártói és felhasználói fejlesztés irányul arra, hogy a technikát tökéletesítse és kibővítse.

Célul tüztem ki azt, hogy olyan új elrendezéseket és mérési módokat tervezzek és valósítsak meg az SMLM technikákhoz, amelyek megörzik a laterális lokalizációs precizitást és a feloldást. További követelmény, hogy egy már meglévö mikroszkóp rendszeren egyszerü módosításokkal is megvalósíthatóak legyenek a fejlesztések.

A kitüzött kutatási cél megvalósításához az alábbi lépések, részfeladatok elvégzését terveztem:

I. Egy anti-Stokes fluoreszcencia elvén müködő, a mintáról kiegészítő informácók kinyerését lehetővé tevő mérési technikára teszek javaslatot.

II. Megtervezek és szimulátorban ellenőrzök egy hatékony fotongyüjtésre alkalmas optikai leképző rendszert, amely akár modalitásokkal is használható, de azok negatív hatásai nélkül.

III. Az előző pontban javasolt kétobjektíves mikroszkópot megépítem, és kvantitatív SMLM mérésekben vizsgálom használatát.

IV. A többszínű modalitás problémáját megkerülve kidolgozom a muslica indirekt repülőizom SMLM mérésének és adatfelolgozásának lépéseit. 


\section{Módszerek és eszközpark}

A disszertációmhoz a méréseket az AdOptIm csoport dSTORM-CLSM-FLIM saját építésü mikroszkópján végeztem, aminek felépítésében és fejlesztésében aktívan részt vettem, veszek. Mivel az új tudományos eredmények bemutatásánál többször is előkerül a mikroszkóprendszer és a kialakított hardveres-szoftveres környezet a rajta végrehajtott változtatások kapcsán, ezért ebben a fejezetben jelenlegi (pillanatnyi) felépítését foglalnám össze csak az általam használt elemekkel. (Emiatt például a DIC és fáziskontraszt lehetőségekről nem is ejtek szót.)

\subsection{Gerjesztés és nyalábkondicionálás}

Gerjesztő forrásként több látható tartományban működő lézer beépíthető és használható széleslátóterü fluoreszcens módban. Az egyes hullámhosszaknál jelöltem a gyáritól eltérő módosításokat és kiegészítéseket. A későbbi fejezetekben csak a hullámhossz szerint utalok az egyes lézerekre:

647 nm. MPB Communications Ltd. 2RU-VFL-P-300-647-B1, 300 mW. A Nikon lézer egységen található.

640 nm. Cobolt Bolero, 300 mW. TIRF típusú megvilágításokhoz használt hullámhossz, a nyalábtágítás egy $3 \times$ Galilei teleszkóppal történik.

634 nm. Thorlabs HL63133DG, 170mW. A dióda egy Thorlabs TCLDM9 fejben található, amit egy Thorlabs LDC500 vezérlő hajt meg. A vezérlő szoftveres kezelése egy saját fejlesztésű Arduino UNO R3 alapú áramkörrel és egy hozzá írt LABVIEW kezelőfelülettel történik [S1], A lézerfényt egy Thorlabs FL635-10 szürővel tisztítjuk.

561 nm. Cobolt Jive, 300 mW. Polarizáció tartó optikai szálba csatolva, melynek kimenete a Nikon lézer egységen található.

405 nm. Nichia NDHV310APC, 70mW. A dióda egy Thorlabs LDM9T fejben található, amit egy Thorlabs LDC205C vezérlő hajt meg. A vezérlő szoftveres kezelése egy saját fejlesztésű Arduino UNO R3 alapú áramkörrel és egy hozzá írt Ni LABVIEW kezelőfelülettel történik [S1]. A nyaláb polarizáció tartó optikai szálba van csatolva a térszűrés miatt, aminek kimenete a Nikon egységen található. 
A Nikon lézer egységen található nyalábok átmenő teljesítménye egy akuszto-optikai modulátor (AOTF) segítségével állítható, a nyalábtovábbítás két kimeneti porton történhet a széleslátóterü- és a CLSM módokhoz. A széleslátóterű mód esetén az egyes hullámhosszak szerint újra szétbontásra kerülnek nyalábkondícionálás végett (divergencia korrekció, nyalábméret állítás, polarizáció manipulálás), valamint további három hullámhossz itt kerül felfüzésre a nyalábútra. Az egyes optikai elemeket részletesen a 4.1. ábrán tüntetem fel. A fó nyalábúton ezek után két kitüntetett síkban állítható tükrök találhatóak, amelyekkel a mintát gerjesztő lézernyaláb irányát lehet állítani [108].

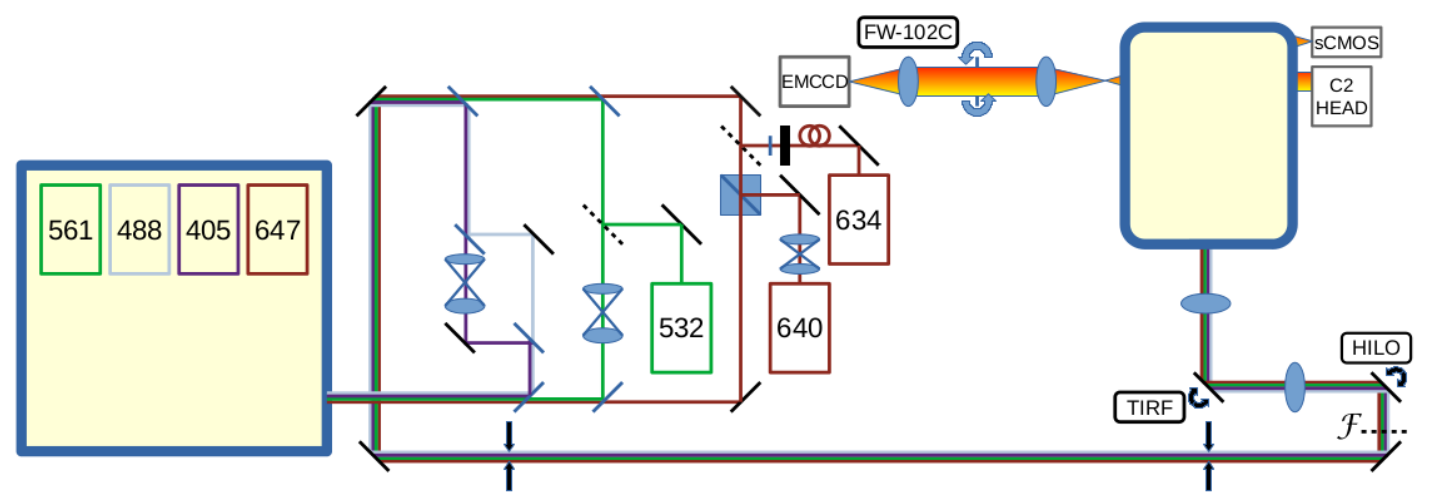

4.1. ábra. Az AdOptIm csoport $\boldsymbol{d} \boldsymbol{S T O R M - C L S M - F L I M ~ m i k r o s z k o ́ p j a ́ n a k ~ g e r j e s z t o ̋ , ~}$ nyalábkondicionáló és detektor elrendezése.

\subsection{Mikroszkóp váz}

A saját építésű mikroszkóp rendszerünk egy Nikon Eclipse Ti-E vázra épül. A minta mozgatása egy motorizált xy asztallal és egy további z piezoval (MadCity Labs Nano-Z Series) lehetséges. A minta z-irányú elmozdulását a Nikon Perfect Focus System követi és korrigálja. A motorizált objektív tartóban a következő objektíveket emelném ki [109], amelyekre a gerjesztő lézerekhez hasonlóan, a nagyításuk szerint utalok:

20x. CFI S Plan Fluor ELWD 20XC- változtatható fedőlemez korrekciójú levegő immerziós objektív, kereséshez.

60x. CFI Plan Apo Lambda 60X Oil - képsík korrekciót tartalmazó olaj immerziós objektív, elsősorban CLSM és FLIM mérésekhez. 
100x. CFI Apo TIRF 100XC Oil - változtatható fedőlemez korrekciójú, nagy numerikus apertúrájú olaj immerziós objektív, dSTORM és TIRF mérésekhez.

Méréseim során az alábbi négy dikroikus tükör és emissziós szűrő párt használtam a motorziált tárból:

Q561. Semrock Di03-R405/488/561/635 + Semrock FF01-446/523/600/677

Q532. Semrock Di01-R405/488/532/635 + Semrock FF01-446/510/581/703

HP647. Semrock Di03-R635 + Semrock BLP01-647R

HP450. Chroma ZT458rde + Chroma ET460lp

\subsection{Detektor karok}

A mikroszkóp vázon összesen három portra szerelhető detektor. Az E100 porton található az okulár és az oldal port, amin egy Cairn OptoSplit II+Bypass rendszer található egy Andor Zyla 4.2 sCMOS kamerával. Az L100 porton található a Nikon C2 konfokális pásztázó fej, benne egy 4 sávos dikroikus tükör, amely a Laser Unitból érkező lézer hullámhosszaihoz lett választva. Az R100 porton egy egyszeres nagyítású, két tubuslencséből (Thorlabs ITL200) álló 4f teleszkóp található. A minta Fourier-síkja így elérhetővé tehető, ahová PSF módosító elemek és extra emissziós szűrők helyezhetőek be. A kar végén található az Andor iXon Ultra 897 EMCCD kamera.

Az R100 porton található 4f teleszkópban (a Fourier-síkban) egy további emissziós szürőt lehetett beforgatni ((Thorlabs FW102C), amelyben a következő szűrőket használtam: Semrock BLP01-647R, AHF 690/70 H Semrock FF01-600/37-25, Semrock FF01-582/7525 és Semrock FF01-520/44-25.

\subsection{LSM Upgrade Kit}

Az eddig tárgyalt mikroszkóp rendszer ki van egészítve a konfokális egységen keresztül egy független, időbontott fluoreszcencia méréseket lehetővé tevő PicoQuant FLIM/FRET rendszerrel. Ehhez külön impulzus-üzemü dióda lézerek tartoznak 640, 560, 480 és 405nmes hullámhosszakon, valamint két saját hibrid detektorral rendelkezik. A detektorokhoz saját szüro” kocka tartozik, amelyek közül a „DM:635LP + Ch1: ET600/50m + Ch2: 
Semrock BLP01-647R" kombinációt használtam. A kiegészítő elemek vezérléséhez és foton érkezési idők kiértékeléséhez a készülékhez kapott SyMPноTime 64 szoftvert használtam.

\subsection{Szuperrezolúciós dSTORM képalkotás}

A mintaelőkészítés során a tároláshoz használt foszfát bufferes sóoldat (PBS) $50 \mu l$ térfogatú glükózoxidáz és merkaptoeltilamin (MEA) alapú GLOX switching buffer-re [71] lett cserélve. A fedőlemezt és tárgylemezt kétkomponensü szilikon alapú ragasztóval zártuk le. Az SMLM mérésekhez a fluoreszcens mintát a $647 \mathrm{~nm}$-es lézerrel világítottam ki epifluoreszcens módon 200-300mW kimenő teljesítménnyel. A mérések során a Q561 és a HP647 filter kocka volt használatban, ha szükséges volt, akkor további emissziós szürő beforgatásával csökkentettem a hátteret. A kapcsolási eseményekből származó emissziós jelet a 100x objektív gyüjtötte össze és a 4f teleszkópon keresztül az EMCCD kamera készített felvételsorozatot tipikusan 20-30ms expozíciós idővel, 20 - 50 ezer képkocka hosszan. A mintára vetített pixel méret $160 \mathrm{~nm}$ a rendszerben. A megvilágított terület tipikus mérete a mintán $\approx 1600 \mu m^{2}$, ami $256 \times 256 p x^{2}$-nek felel meg. Ha reaktiválásra volt szükség, akkor azt a 405nm-es vagy a 488nm-es lézer teljesítményének változtatásával történt. A fedőlemez fókuszban tartásához a Nikon PFS rendszer folyamatosan aktív volt.

A felvételek feldolgozása a csapat által fejlesztett lokalizációs szoftverrel, a RAINSTORM-mal [81][S3] történt. Az egyedi kapcsolási események illesztése kétdimenziós Gauss-függvénnyel történt a legkisebb négyzetek módszerével. A szoftver a kapcsolási események koordinátájának a függvény maximumhelyét vette. Az egyes eseményeket lehetöség volt konstans vagy lineáris háttérrel, szimmetrikus vagy elliptikus Gauss-függvénnyel illeszteni a mérési körülmények és a használt modalitás szerint. A rekonstrukció az egyszerü hisztogram (Simple Histogram) módszerrel történt, amely az egyes szuper-pixeleket úgy alakította ki, hogy az adott területre eső események számát feleltette meg a beütésszámnak. Laterális drift eltávolítás a beépített kereszt korreláción alapuló algoritmussal történt [110]. A rekonstrukcióhoz felhasználható események tipikusan a $0,7 p x \leq W_{x y} \leq 2 p x$ és $0 n m \leq \Delta x \leq 45 n m$ szürők alapján kerültek kiválasztásra. A paraméterektől való eltérést a tézispontok eredményeinél jelzem, ha a kapcsolódó mérés során szükséges volt. 


\section{5. Új tudományos eredmények}

Ebben a fejezetben részletesen bemutatom a kitűzött célokhoz kapcsolódó új tudományos eredményeket, és alfejezetenként tárgyalom a tézispontokhoz vezető megállapításokat. Egy-egy ilyen egységet a probléma felvetésével és kifejtésével kezdek. A tisztázott peremfeltételek után mérési eredményekkel támasztom alá a megoldás lépéseit. Végezetül az alfejezetet összefoglalva megfogalmazom az adott tézispontot.

\subsection{Az Alexa Fluor 568 festék anti-Stokes fluoreszcencia tulaj- donsága}

Többszínű szekvenciális dSTORM méréseknél, ahogy az a 2.4. ábrán is látható, megfelelően választva a gerjesztést és az emissziós szűrők ablakait elérhető az, hogy minimális legyen az áthallás az egyes csatornák között. Csak vörösben gerjesztve $(647 \mathrm{~nm})$ az lenne a várt eredmény, figyelembe véve a Stokes-eltolódást is, hogy a Semrock FF01-582/7525 szűrő által kijelölt „zöld” csatornában ne legyen jel. Mi történik akkor, mikor egy AF647-tel és AF568-cal kettősen jelölt mintán mégis sikerül olyan jelet mérni, ami az előző állításnak ellent mond? Red-edge gerjesztéshez [9] a gerjesztő lézer hullámhossza már a mérhető abszorpciós spektrumon kívül volt.

Az első feltevés természetesen az, hogy a mi épített mikroszkóp rendszerünkben van a hiba 2 A jelenséget azonban más mikroszkópon, és konfokális detektálási módban is sikerült reprodukálni ugyanazon a mintán. A következő feltevés az immunhisztokémiával, valamint a FRET jelenségével volt kapcsolatban az antitestek méretei miatt. E szerint az elsődleges antitest gerjeszthető, több nem sugárzó átmenettel energiát adhat át a festéknek, ami végül fluoreszcenciával relaxálódik. Azonban a jelenséget más elsődlegesmásodlagos kombinációban is detektálni lehetett az AF568 festékre, festék nélküli minta esetén nem volt tapasztalható. Egyetlen gyanúsított maradt, az AF568 festék, amit a spektrális és FLIM mérések is alátámasztottak. A talált jelenség gyors volt, az emissziós spektrumot látszólag nem befolyásolta, azonban a Stokes-eltolás mégsem a megszokott irányba történt.

Következő lépésben azt vizsgáltam meg, hogy a jelenség csak az AF568 festékre jellem-

\footnotetext{
${ }^{2} \mathrm{~A}$ vélt energiamegmaradást sértő folyamatokkal kapcsolatban egy kutató nem kiállt azonnal farkast.
} 
ző, vagy esetleg másikkal is reprodukálható. Ezért az SZTE Optikai és Kvantumelektronikai Tanszéken korábban festéklézerek kutatására használt, és hasonló molekulaszerkezettel rendelkező szerves festékeket (Rh110, Rh6G, Rh101) kezdtem el hasonló körülmények között vizsgálni. Rh110 és Rh6G esetén 561nm-es gerjesztéssel sikerült az 520/44 ablakban kimutatni a jelenséget, valamint Rh101 esetén az AF568-cal megegyezőek voltak a tapasztalatok. Az irodalomban ezekre a festékekre nézve azonban már találtam leírást, a jelenség neve az anti-Stokes fluoreszcencia, vagy felkonverziós (upconversion) fluoreszcencia. A tulajdonságait és lehetséges gerjesztési modelljeit a 2.1. alfejezetben tárgyaltam.

\subsection{1. Összehasonlító festékelemzés}

Négy kísérletet terveztem és végeztem el a dSTORM mérésekhez használt AF568 festék felkonverziós viselkedésének körülírására, hogy tudományos alapokra helyezve tisztázzam azt, hogy melyik gerjesztési modell érvényes rá. Hogy a mérési eredmények értelmezésében legyen mire támaszkodni az irodalom számára már forró energiasávos elnyelési tulajdonságairól ismert festéken [26], Rh101-en is mértem párhuzamosan.

Az első kísérletben az abszorpció hatáskeresztmetszetére és az emittált jel linearitására voltam kíváncsi különböző hullámhosszakon történő gerjesztés mellett. Ha a folyamat ugyanis a forró energiasávokat használja elnyeléshez, akkor a hullámhossz növelésével csökkennie kell az emittált fény intenzitásának, mivel csökken a gerjeszthető vibrációs energiasávok betöltöttsége. A gerjesztéshez a 634nm, 640nm és 647nm hullámhosszú lézer forrásokat használtam, amelyek nyalábútjait egymásra füztem. A lézerek teljesítményét a 60x objektív után kimértem energiamérővel (Thorlabs PM200; Thorlabs S140C) különböző AOTF beállítások és dióda-áramerősségek mellett. A festékeket $10^{-4}$ hígításban (metanol-PBS oldat) egy-egy tárgylemezre cseppentettem, amit fedőlemezzel lefedtem, lezártam, majd felhelyeztem a mikroszkópra. A szürő-kockák közül a Q532-est használtam kiegészítve a 582/75 ablakú emissziós szürővel. Minden vörös hullámhosszúságon ellenőriztem a kivilágított terület méretét és a homogenitását, majd különböző teljesítmény beállításoknál 100ms expozíciós idővel felvételeket készítettem a nagyobb hullámhossztól a kisebb felé haladva. Mindegyik felvétel adatsorát illesztettem Gauss-nyalábos megvilágítást feltételezve. Ehhez saját szoftvert használtam és a detektoron mért beütésszámok zajcsökkentése miatt volt rá szükség S5. A kapott eredményeket az 5.1. ábrán összegez- 
tem.
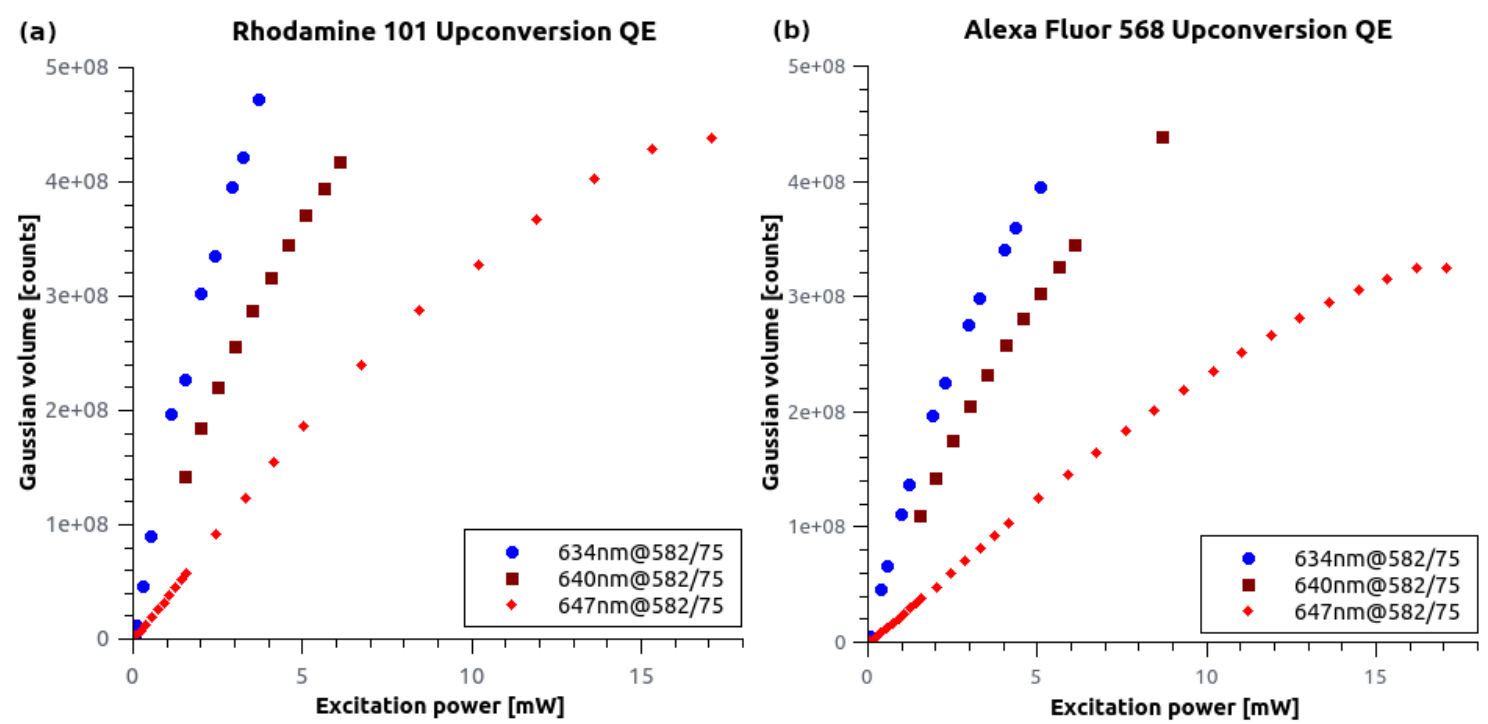

5.1. ábra. Az abszorpciós és emissziós hatásfok hullámhossz függése $\boldsymbol{R h 1 0 1}$ és $\boldsymbol{A F 5 6 8}$ esetén. Mindkét grafikonon látszódik, hogy a hullámhossz növelésével csökken a hatáskeresztmetszet, ami a gerjeszthetö vibrációs állapotok alacsonyabb számára utal. Nagyobb teljesítmények esetén a kamera erösitése nem volt lineáris, ezért látható a telitődésre utaló effektus. Forrása [A3].

Az első kísérlet eredményei alapján legalább három fontos megállapítás tehető mindkét festékre. A felkonverziós folyamat során lineárisnak tekinthető a kapcsolat a gerjesztési teljesítmény és az emittált fotonok száma között alacsony teljesítmény esetén. Növelve a gerjesztő fény teljesítményét a mért fluoreszcencia növekedés eltér a lineáristól. Nagyobb kimenő teljesítmény tartományon $(30-300 \mathrm{~mW})$ és rövidebb expozíciós idővel $(20 \mathrm{~ms})$ megismételve a mérést hasonló eredményeket lehet kapni. Levonható a következtetés, hogy nem telítődő abszorpció vagy többfotonos folyamat áll a háttérben. Az eltérést az EMCCD kamera telítődő, nemlineáris erősítése okozza 6000-res beütésszám felett 111. Az anti-Stokes fluoreszcencia már kis teljesítményen is jelentkezik, a mért tartományon nincs küszöbértéke. Felkonverziós folyamat során nagyobb hullámhosszhoz kisebb abszorpciós hatáskeresztmetszet tartozik, ami magyarázható az adott hullámhosszal gerjeszthető vibrációs állapotok ritkaságával. Ezek a megállapítások alapján a kétfotonos elnyelési modell kizárható, ugyanis ott az anti-Stokes emisszió a gerjesztő fény teljesítményének négyzetétől függ. 
A második kísérletben az emissziós spektrumra voltam kíváncsi, hogy normál és felkonverziós esetben mennyire egyezik meg. A gerjesztéshez a 405nm, 561nm és a $634 \mathrm{~nm}$ hullámhosszú lézereket használtam. Normál fluoreszcencia esetén azért került bele ilyen alacsony hullámhosszú lézer is, mert rendelkezésre állt olyan szűrőkocka (HP450) amivel a teljes emissziós spektrum felvehető volt. A mikroszkóp E100 oldalportján az emittált fényt 200um magméretű multimódusú optikai szálba csatoltam, hogy a spektrumot egy OceanOptics QE65000 spektrométerrel le tudjam mérni. Az Rh101 mintát 10², míg az AF568 mintát $\sim 10^{-5}$ hígításban készítettem el. Az anti-Stokes emissziós spektrumokat a Q532 szűrőkockával vettem fel, majd az infra tartományban a háttérről is készítettem ellenőrző méréseket a HP647 szürőkockával. A lementett normál és felkonverziós spektrumokat normáltam és festékenként az 5.2 ábrán összegeztem a 405nm és $634 \mathrm{~nm}$ gerjesztés esetén.
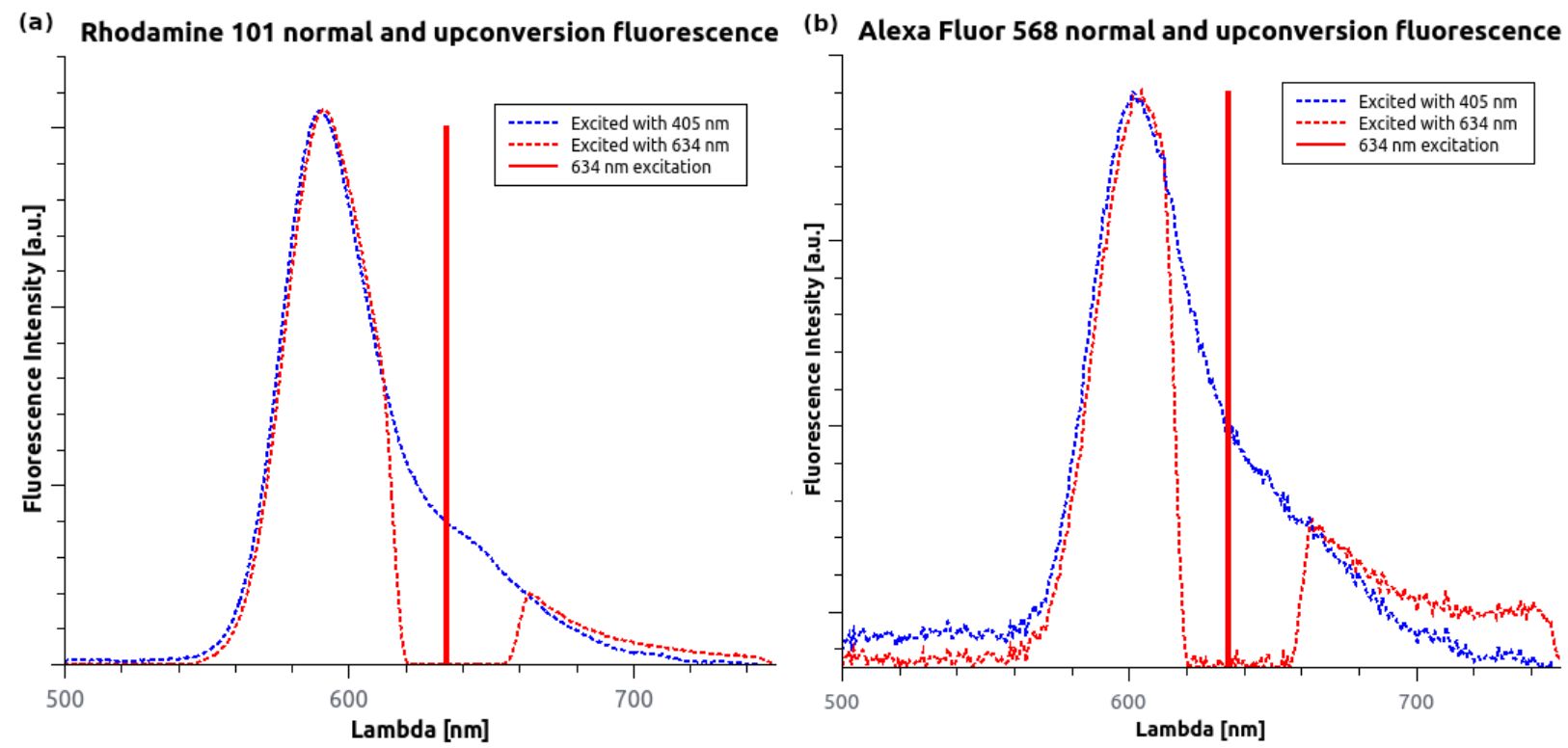

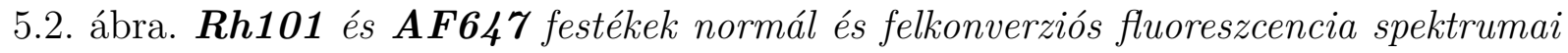
normálva. A felkonverziós esetben olyan szürőkockát kellett választani, ami a gerjesztö lézert nem engedi át. A $700 \mathrm{~nm}$ feletti tartományban egy mintától független konstans háttér volt mérhetö. Forrása [A3].

A második kísérlet eredményei alapján megállapítható az, hogy a háttértől eltekintve a normál és felkonverziós spektrumok alakjai megegyeznek, maximum helyeik $\approx 1-$ -1,5nm-rel vörös irányba vannak eltolódva felkonverzió esetén. A jelenség magyarázatára 
a tudományos irodalomban az oldott anyag és az oldószer kapcsolatát találtam, én részletesen nem foglalkoztam vele [9, 112, 113, 114]. A felvett spektrumok nem tartalmaztak $T_{1} \rightarrow S_{0}$ átmenethez köthető további csúcsot. Ezek alapján megállapítható hogy a domináns relaxációs folyamat az $S_{1} \rightarrow S_{0}$ átmenet, tehát fluoreszcencia, a gerejesztés módjától függetlenül. Mindkettő szerves festékre ugyanazt az eredményt kaptam ennél a kísérletnél is.

Hogy az utolsó megállapítás helyességéről egyértelmüen megbizonyosodjak, egy harmadik kísérletet terveztem, amellyel a forró energiasávos elnyelést mutatom ki, annak hőmérséklet-függése kapcsán. Ha a triplett állapotra épül az ismeretlen gerjesztési modell, akkor a hőmérséklettől csak kis mértékben függ az abszorpció hatásfoka. Ellenkező esetben már szobahőmérséklet tartományon is erös függést kell mérnem a hömérséklettől. A méréshez Peltier-elemmel hőmérséklet szabályozott lézerdióda fejnek (Thorlabs TCLDM9) adtam ideiglenesen és reverzibilisen új célt. A fejben található rézlaphoz hővezető pasztával és kétkomponenses szilikon ragasztóval rögzítettem egy üveg tárgylemezt. Az Rh101 és AF568 festékekeket $10^{-5}$ hígításban (metanol-PBS oldat) készítettem el, majd mérésenként a tárgylemezre cseppentettem és fedőlemezzel lezártam. Azért választottam ezt az oldat kombinációt, mert a csak metanolt tartalmazó minták gyorsan kiszáradtak. A módosított lézerdióda fejet a motorizált mintatartó asztalhoz rögzítettem. A 20× objektívvel a fedőlemez belső felületére állítottam a fókuszsíkot. Azért esett levegős objektívre a választás, mert nem akartam termikus kapcsolatot a vizsgálandó mintával.

A mérésekhez a CLSM fejet vonalpásztázó módban használtam az átlagolás és kiégés elkerülése miatt. Gerjesztéshez a 640nm-es impulzus üzemű lézert használtam OD1 gerjesztési szürővel, míg detektáláshoz a hibrid detektorokat a PicoQuant LSM Upgrade Kit rendszerből. A mérés elején a fedőlemezre álltam, és bekapcsoltam a PFS fókusztartó rendszert. A fókuszsíkot úgy állítottam be, hogy a fedőlemez felett, a festékoldatban legyen 500nm-1000nm távolságra. A hőmérsékletet 4 fokonként változtattam, és annak beállása után 60 másodperces felvételeket készítettem a detektorokra érkező emittált jelről. A mérést $12^{\circ} \mathrm{C}$ és $48^{\circ} \mathrm{C}$ fok között többször megismételtem mindkét irányba, hogy az esetleges hiszterézist vagy a festék kiégését tudjam ellenőrizni. Az egyes hőmérsékletekhez tartozó méréseket csatornánként szétbontottam, átlagoltam és hibát számoltam. A kapott eredményeket az 5.3 , ábrán foglaltam össze anti-Stokes esetben. Azonban a mérések hi- 
bája az egyes hőmérsékleti pontoknál nem került feltüntetésre, mert azok kisebbek voltak $\operatorname{mint} 1 \%$.

(a) 20MHz OD1

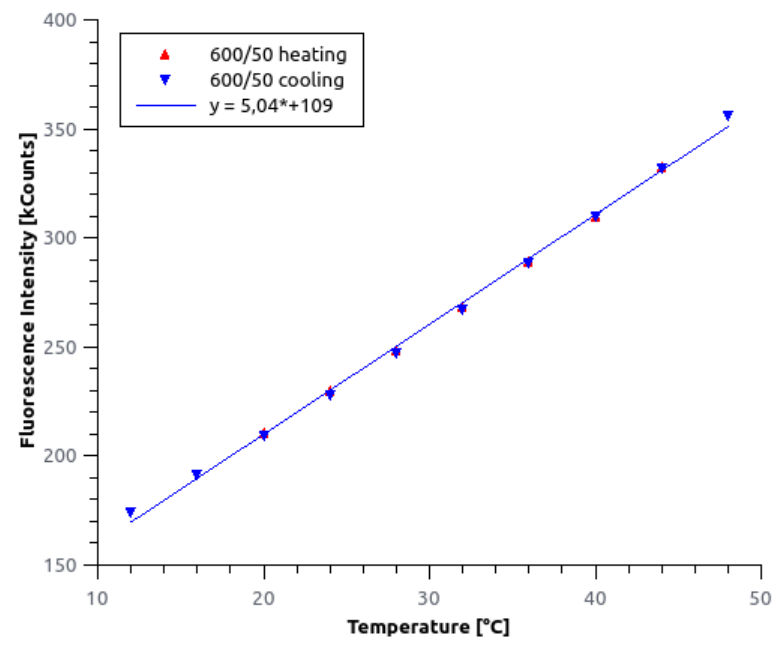

(b) Alexa Fluor 568 upconversion fluorescence $640 \mathrm{~nm}$ 20MHz OD1

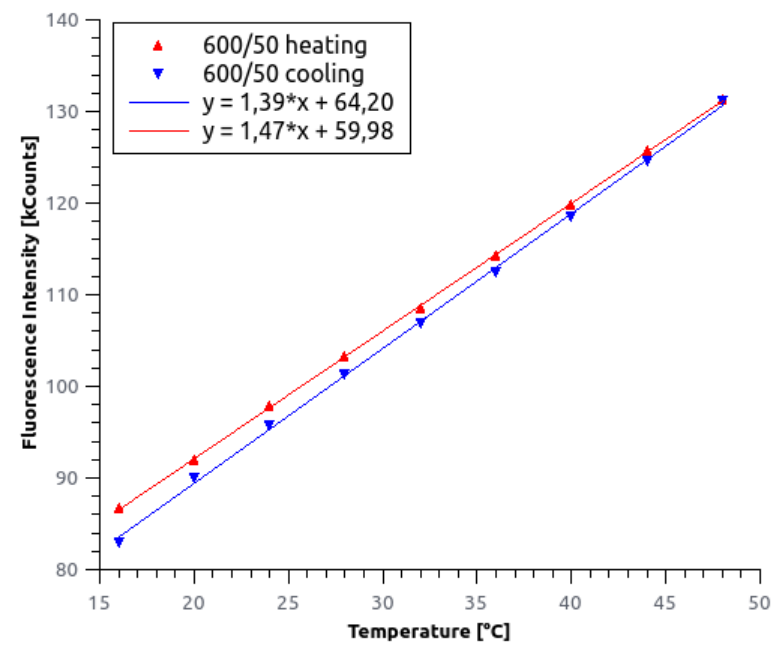

5.3. ábra. Az anti-Stokes fluoreszcencia hömérséklettől való függése. $\boldsymbol{A} \boldsymbol{F 5 6 8}$ esetén a fütés $\rightarrow$ hütés ciklus során láthatóvá vált az intenzitás csökkenés, feltehetöen a festékek kiégése miatt. Forrása [A3].

Kontroll mérést is végeztem, hogy ellenőrizzem 560nm-es impulzus-üzemü gerjesztés mellett az AF568 mintát. A beütésszám nem mutatott hőmérséklet függést, végig 30kCount közelében volt OD3-as gerjesztési szürő használatával. A Rh101 grafikonon a mérési pontokra illeszthető egyenes meredeksége $\approx 3,5$-szöröse az AF568 festéknek, ami erősebb hőmérséklet függésre utal. Az AF568 esetén tapasztalható volt egy enyhe intenzitás csökkenés (feltehetően kiégés) többszörös fütés és hütés után, a Rh101 esetén viszont nem volt számottevő. A meredekség a koncentrációtól is függ, de ez a gerjesztett térfogatban lévő festékek számával kapcsolatos. Illetve azt megjegyezném, hogy a hőmérséklet-intenzitás kapcsolata a teljes hőmérsékleti tartományon feltételezhetően nem lineáris, a Bolzmann statisztikából kiindulva inkább exponenciális függvényt követ $I(T)=$ $=A \cdot e^{-b / k_{B} T}$ alakban. A választott hőmérséklet-tartomány miatt az exponenciális függvény ezen szakasza inkább hasonlított egy lineáris függvényre. A harmadik kísérletben kapott eredmények alapján megállapítható az, hogy emittált fotonok száma erős hőmérséklet függést mutat. Ez a forró-energiasáv abszorpciós modellt erősíti mindkét festék esetében.

Egy negyedik, utolsó kísérletet is terveztem, amely során a fluoreszcencia élettarta- 
mok viselkedésére voltam kíváncsi Stokes és anti-Stokes esetben. A legerősebb bizonyítékot ugyanis ez adja arra vonatkozóan, hogy a folyamat csak fluoreszcenciához köthető vagy triplett állapotok is részt vesznek a relaxációs folyamatban. A gerjesztéshez $560 \mathrm{~nm}$ és 640nm hullámhosszúságú impulzusüzemü lézereket használtam OD3 és OD1 szürőkkel, hogy a beütésszámokat azonos szinten tartsam a hibrid detektorokon. Az kísérletben használt minták megegyeztek az elsőben használt mintákkal, valamint ugyanúgy a 60x objektívet használtam. Négy FLIM mérést végeztem pontdetektálási módban, a 600/50es detektálási csatornában kapott fotonérkezési-időkre Tail Fit módszerrel egy-egy exponenciálist illesztettem, amiből megkaptam a fluoreszcencia élettartamot. Az illesztett érkezési idők, a rendszer becsült válaszideje (IRF), és az élettartam mérésenként az 5.4 . ábrán látható.
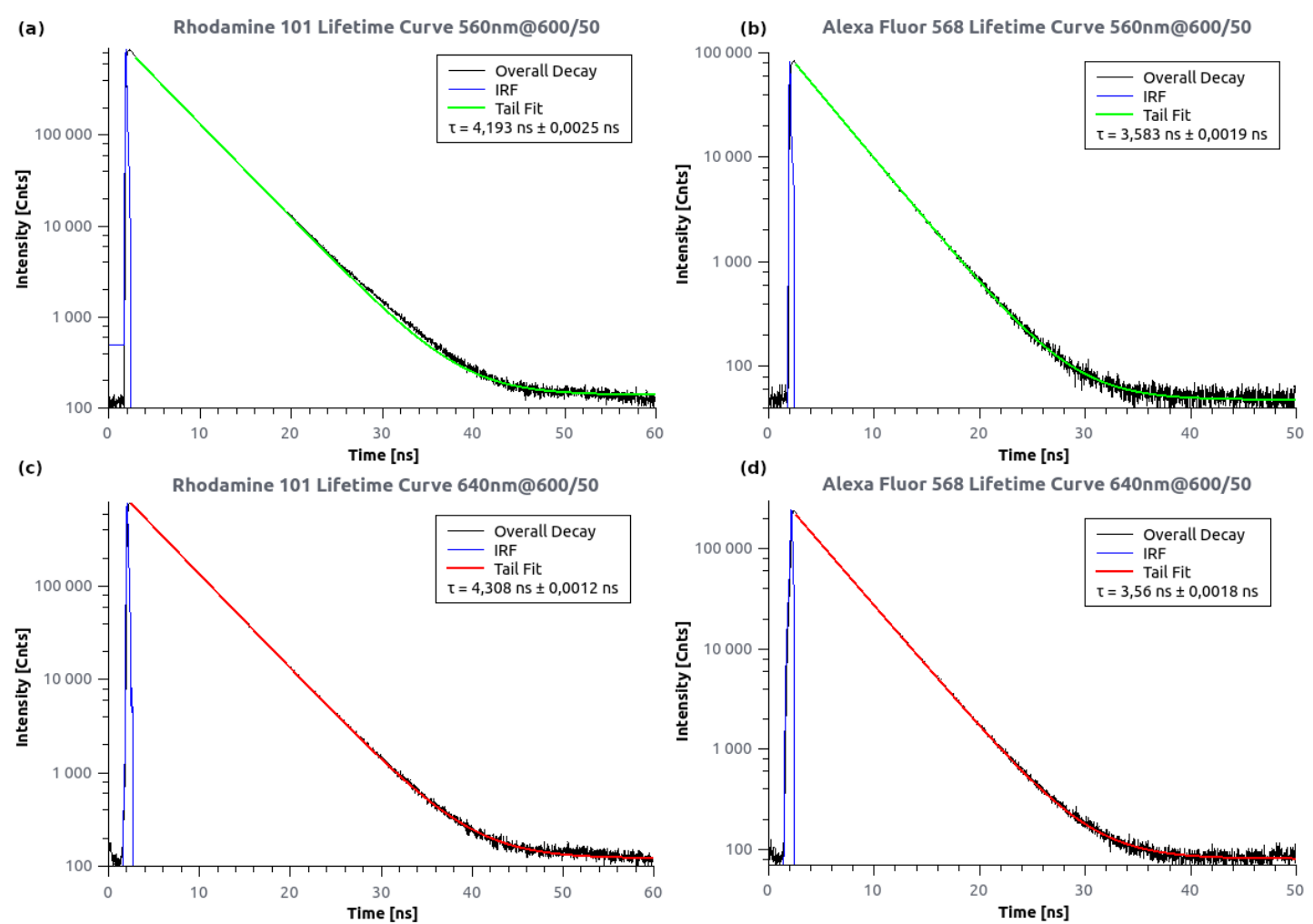

5.4. ábra. Rh101 és $\boldsymbol{A F 5 6 8}$ festékek normál és anti-Stokes fluoreszcencia élettartamai 'Tail Fit' modellel illesztve. Felkonverziós esetben az IRF kiszélesedését gyors folyamatok okozzák. Forrása [A3].

Res ipsa loquitor. Az eredmények magukért beszélnek, az illesztett élettartamok Stokes és anti-Stokes fluoreszcencia esetén szinte megegyeznek $(\sim 0,1 n s)$. Ami érdekes tapasztalat 
volt, hogy az anti-Stokes fluoreszcencia esetén mindkét festéknél a becsült IRF kiszélesedett. Ez feltehetően a szoftverben egy hiba, hogy nem tudja kezelni a nagyon gyors $(<1 n s)$ folyamatokat. Hasonló jellegű méréseket végezve egy AF647-es mintán nem volt tapasztalható ez a kiszélesedés. Emiatt használtam mind a négy méréshez Tail Fit modellt, és festékenként közel azonos élettartamokat kaptam mindkét gerjesztésnél. Ezzel a kísérlettel már egyértelmüen bizonyítva lett, hogy az AF568 esetén a keresett anti-Stokes fluoreszcencia modell a forró energiasáv abszorpció.

\subsubsection{Az anti-Stokes fluoreszcencia EPI és dSTORM mérések során}

Az anti-Stokes fluoreszcencia jelenségét figyelembe kell venni a biológiai minta jelölésének megtervezése során. Abban az esetben, ha a fluoreszcens mikroszkóp csak a gyári négysávos fluoreszcens kockát tartalmazza (4.2. alfejezet) és nem tartalmaz további sávszürőket, akkor a felkonverzióra gerjeszett festéktől származó jel meg fogja emelni a hátteret, csökkentve ez által az elérhető kontasztot. A jelenség azonban kihasználható akár az előnyünkre is. Az AF568 festék forró energiasávos abszorpciójának bizonyítása során felmerültek alkalmazási lehetőségek, amelyeket egy-egy próbakísérletben, illetve példákon keresztül tárgyalnék is a továbbiakban.

Lokális hömérséklet mérés modalitás • SMLM mérések kapcsán nem találtam olyan tudományos közleményt, ami a biológiai mintán belüli hőmérséklettel és a hő által okozott roncsolással foglalkozna. A forró energiasávos abszorpciót kihasználva a keresett információ azonban kinyerhetővé tehető. Ez lehetőséget teremtene arra, hogy egy kettősen festett a mintában adott helyen meg lehessen mondani a hőmérsékletet és annak mérés alatti megváltozását. Ehhez olyan szerves festéket kell használni, vagy annak olyan környezetet (oxigén elvonás, triplett kvencser) kell teremteni, amely során az nem ég ki számottevően. A kalibrációhoz csak meg kell mondani a vizsgálandó területen belül a lokális koncentrációt. Ez történhet intenzitás alapon normál fluoreszcencia méréssel, vagy egy tényleges anti-Stokes fluoreszcencia kalibrációval a mérés előtt Peltier-elemet használva.

Az ötlet teszteléséhez kettősen jelölt muslica miofibrillum szálakon (tropomodulinAF647, b2-AF568) végeztem méréseket. Azért esett erre a mintára a választás, mert ez egy valós biológiai minta, akár 2-3 hónapon át is tárolható, és nagyon sok tapasztalatot 
gyưjtöttem róla dSTORM mérések kapcsán (5.4. alfejezet). További előnye az, hogy a szarkomer bizonyos fehérje struktúrái (amelyeket az 5.4. alfejezetben tekintek át) meghatározott, feloldás alatti távolságokra lévő kettős vonalakat alkotnak. A kritérium az, hogy ha új modalitást fejlesztek, akkor annak fel kell tudni oldania ezeket a távolságokat. A gerjesztéshez a 640nm-es lézert használtam 300 $\mathrm{mW}$ teljesítménnyel. Az emissziós spektrumot a Q561 szürőkockával választottam le a detektor karban. A mintából emittált fényt az E100 oldalporton keresztül egy Opto Split II+Bypass (Cairn) nyalábosztó eszközzel a spektrális ablakok szerint két képre bontottam. A bontás végén az egyes nyalábutakban a 600/37 és 690/70 optikai szürőket használtam, hogy a festékek emissziós jeleit elkülönítsem. Az sCMOS kamerával 30ms expozíciós idővel 10000 képkocka hosszúságú felvételt készítettem. A mintára vetítve a pixelméret 90nm-nek adódott. Az egyes spektrális csatornákat különválasztottam a feldolgozáshoz és a RAINSTORM szoftverrel feldolgoztam a lokalizálható csatornát, míg a másikon FIJI/IMAGEJ szoftverrel intenzitást mértem. A kapott eredmények az 5.5 . ábrán láthatóak.

Megállapítható, hogy az AF647 dSTORM mérése megfelelően sikerült (5.5.b) az optimálistól kisebb pixelméret mellett is, és a kettős vonalak rekonstruálhatóak voltak 5.5.c). A probléma viszont ott jelentkezett, hogy az AF568-hoz köthető másik, antiStokes fluoreszcencia csatorna viszont nem volt használható hőmérséklet mérésre $5.5 . \mathrm{a}$ ). Kiolvasva három-három területről (1-6) az intenzitásokat megfigyelhető, hogy az AF568 festékhez tartozó jel (1) folyamatos csökkenése a kiégés miatt 5.6.a ábra). Ezt a mérés elején és végén $561 \mathrm{~nm}$-es gerjesztés mellett készült képeken is látszódott, tehát a folyamat nem hütéshez volt köthető.

Bár a hőmérséklet mérés nem sikerült AF568 festékkel dSTORM körülmények között, a sokkal stabilabb Rh101-gyel azonban mégis megvalósíthatónak tartom. Élösejtes környezetben EPI mérési módban használva a kiégés elkerülhető a használt alacsonyabb lézerteljesítmények miatt. Sajnos ezek a mérések a tervezőasztalon maradtak idő hiányában (új antitest beszerzése, inkubátor feltét beszerzése, ...).

Két tapasztalati tényt viszont kiemelnék, ami szekvenciálisan rögzített többszínű dSTORM méréseknél negatívan befolyásolja a mérést:

I. Az AF568 festék nagy teljesítményű vörös gerjesztés esetén kiéghet 5.6. a ábra(1)).

II. Az AF568 festék megnöveli a hátteret az AF647-tel kapcsolatos méréseknél, a 


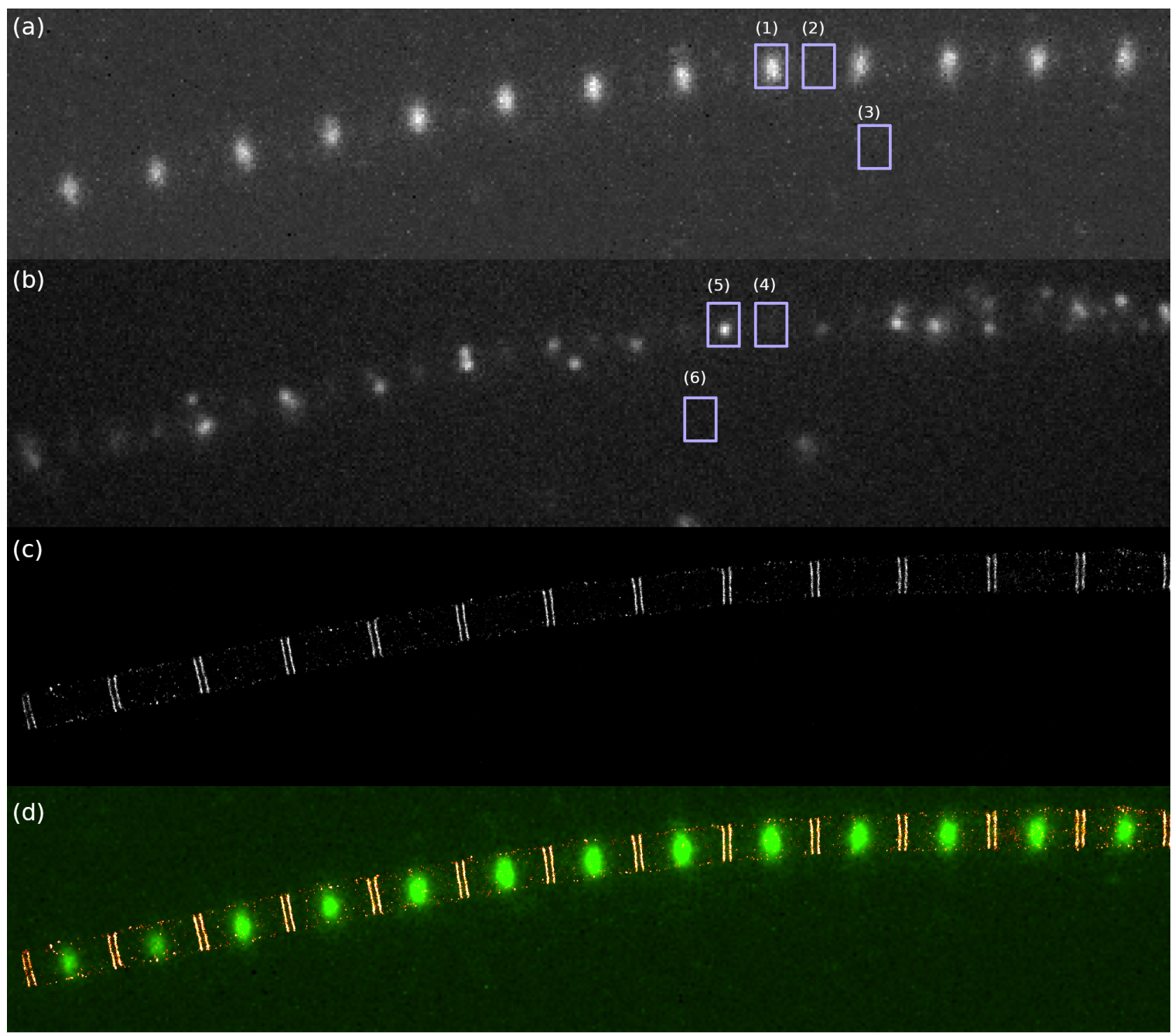

5.5. ábra. Kettösen festett izomszál mintán egyidejü hömérséklet-változás és $\boldsymbol{d} \boldsymbol{S T O R} \boldsymbol{M}$ mérési kísérlete. Az anti-Stokes csatornában jól láthatóak a zónák vonalai, amik sajnos kiégtek a felvételkészités során (a). A (b) ábrán egy kiragadott képkocka látható a $\boldsymbol{d} \boldsymbol{S}$ TORM csatornából, amin észrevehető az $\boldsymbol{A F 5 6 8}$ okozta háttér is. Kiértékelve a képet rekonstruálhatóak a kettös vonalak (c), ami az (a) képkockával megfelelö színezés mellett összevonva kiadja a két festett struktúrát (d). Forrása [A3]. 

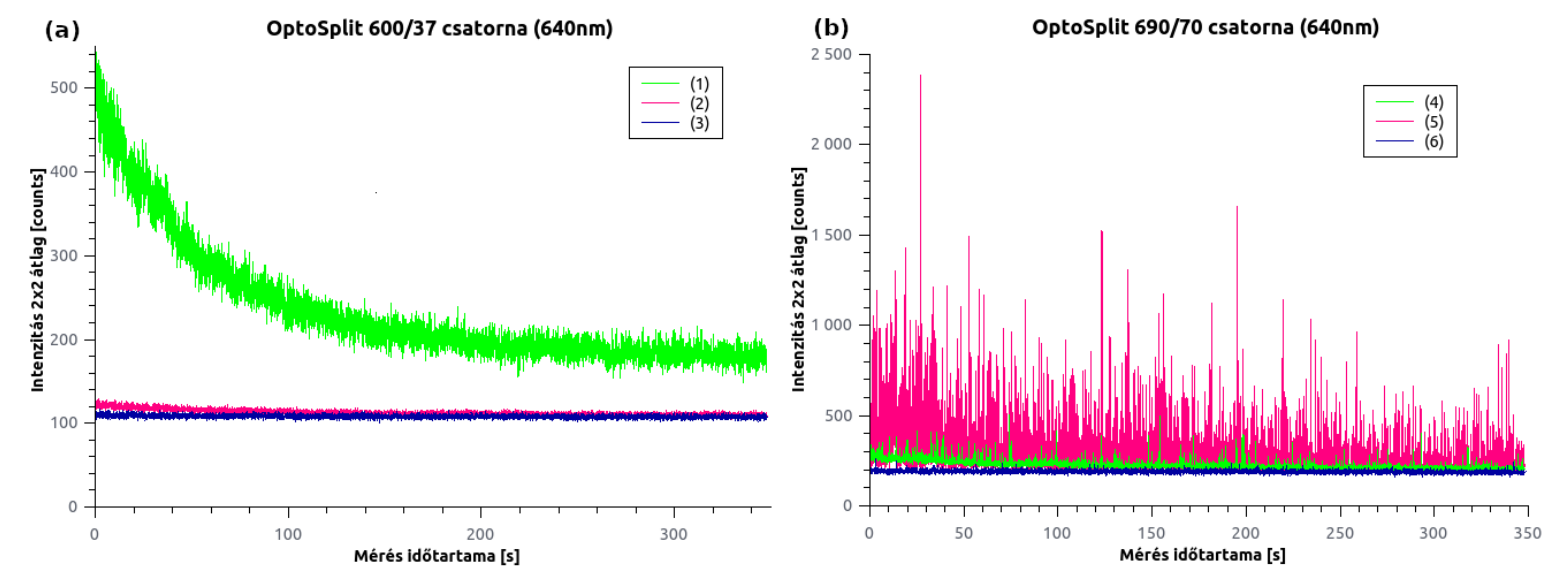

5.6. ábra. Az 5.5. ábra(a-b) képein kijelölt három-három területen belül mért átlagolt intenzitás. Az $\mathbf{A F 5 6 8 - h o z ~ k o ̈ t h e t o ̈ ~ a n t i - S t o k e s ~ f l u o r e s c e n c i a ~ i n t e n z i t a ́ s a ~ ( 1 ) ~ a ~ f e s t e ́ k ~ k i e ́ g e ́ s e ~}$ miatt lecsökken.

forró-energiasávos abszorpció és az emissziós spektrumának áthallása miatt 5.6.b ábra(4)). A mérések során sávszürővel csökkenthető a jelenség.

Bizonyos körülmények között azonban elönyünkre is fordíthatjuk a jelenséget és korábban nehezen kezelhető problémák válnak megoldhatóvá a forró-energiasávos gerjesztéssel. Mindhárom javasolt alkalmazást az általam kezelt projekteken belül felhasználtam.

Autofluoreszcencia-csökkentett képalkotás • Mikroszkópos mérések során kiemelt cél olyan képek készítése amelyek megfelelő jel-zaj aránnyal rendelkeznek. A biológiai mintából származó autofluoreszcencia azonban elrontja a kontrasztot a nemkívánt háttér megnövelésével. Kezelésére pár trükköt az a 2.1. alfejezet végén említettem, azonban egységesen használható megoldást nem találtam. Kihasználva azt, hogy az autofluoreszcencia kvantumhatásfoka tipikusan alacsonyabb, mint a szerves festékeké, valamint azt, hogy a gerjesztés hullámhosszától is függ az ily módon emittált jel erőssége, a probléma megkerülhetővé válik az anti-Stokes fluoreszcenciával. A detekor karban a forró-energiasáv elnyelő festékhez tartozó emissziós szűrőt használva, az emissziós szűrő transzmissziós ablakánál nagyobb hullámhosszal gerjesztve elérhető az, hogy csak az anti-Stokes jelet lássuk a detektorunkon. Bár ez a jel alacsonyabb annál, mint amit a Stokes-i gerjesztéssel kapnánk, azonban mivel mentes az autofluoreszcenciától így hosszabb expozíciós időket használva nagyobb kontrasztal rendelkező felvételek készíthetőek. Ezt a javasolt mérési 
módot már lantanida alapú nanokristályokkal használják [115], azonban a szerves festékek használatával nem kell módosítani a biológiai minta előkészítésének protokollját.

Struktúra keresés és változás követése dSTORM mérés során • Egy agyszövetben a $\beta$ IV spektrin az Axon Iniciális Szegmenseket jelöli a neuronokon [116]. Egy izomsejt tenyészetben a differenciálódást a dezmin felhalmozódása jelzi [117, 118], ennek jelölésével meg lehet különböztetni azt, hogy milyen fázisban vannak az egyes sejtek a tenyészetben. Miofibrillumokban az elasztikus protein komponensek, amelyek az I-csík körül halmozódnak fel, jelölhetőek kettin vagy SLS700(B2) antitestekkel A2. Ha ezeket a tipikus sejtalkotókat forró-energiasáv elnyelő festékkel jelöljük meg a megfelelő antitestekkel, akkor egy többszínü szekvenciális dSTORM mérés során a fő mérés (AF647 dSTORM) az anti-Stokes fluoreszcencia a biológiai struktúra valós idejű követésére vagy annak megváltozának monitorozására használható. Ehhez csak a detektor karban kell a nyalábot ketté osztani spektrálisan (például OptoSplit II+Bypass) és egyazon kamerát használva készíthető el a felvételsor.

Drift korrekció - Az SMLM méréseknél a mintát stabilan kell tartani mindhárom dimenzióban a mérés hosszúsága miatt. A z korrekcióra használhatóak a mikroszkóp vázra építható fókusztartó optikai elrendezések. A laterális korrekciót azonban csak utólag, szoftveresen van lehetőség elvégezni. Ez utóbbihoz fluoreszcens gyöngyök használata, vagy a kapcsolási események keresztkorrelációja szükséges. A fluoreszcens gyöngyökkel az a probléma, hogy a mintán belüli sűrüségüket és eloszlásukat nehéz szabályozni. Ha saját hullámhosszán gerjesztődik, akkor az emittált intenzitása olyan nagy dSTORM teljesítményen, hogy a környező területről lehetetlenné teszi a festékmolekulák lokalizálását. Forró-energiasávos abszorpcióval viszont megoldható az, hogy a megfelelően választott gyöngyök csak kis intenzitással anti-Stokes fluoreszkáljanak [119]. A drift térkép akár egy külön spektrális csatornán felvehető a méréstől függetlenül, például a korábban említett OptoSplit II+Bypass nyalábosztóval. Az ötletet továbbgondolva, ha hengerlencsét helyezünk az anti-Stokes fluoreszcencia detektálásához használt optikai útba, akkor az utólagos z irányú korrekció is megvalósítható olyan mikroszkóp rendszereken, amelyek nem tartalmaznak fókusztartó kiegészítőt. 


\subsubsection{Az eredmények tézispontban megfogalmazva}

[T1]. Az Alexa Fluor 568 forró energiasávos abszorpciójának bizonyításához hullámhossz függést, spektrális tulajdonságot, hőmérséklet függést és fluoreszcencia élettartamot mértem. Méréseimet összehasonlító jelleggel a már ismert Rhodamine 101 és az egymolekula detektáláson alapuló mikroszkópiában használatos Alexa Fluor 568 szerves festékre végeztem el. Megmutattam azt a tudományos irodalomban nem ismert tényt, hogy az Alexa Fluor 568 is forró energiasáv elnyelő. Végezetül javaslatot tettem a forró energiasávos anti-Stokes fluoreszcencia alkalmazására dSTORM és EPI mérések során (autofluoreszcencia-csökkentett képalkotás, struktúra jelölő, laterális drift becslés és lokális hőmérséklet mérés).

Kapcsolódó publikációk: A3, S5 


\subsection{Multi-modális lokalizációs mikroszkóp megtervezése}

Ahogy arra a lokalizációs mikroszkópiás modalitások tárgyalásánál a 2.6. alfejezetben és a 2.3. táblázatban kitértem, a PSF manipulációval járó modalitások alkalmazása elrontja a lokalizációs precizitást (2.8, és 2.9 képletek) és az elérhető feloldást (2.10. képlet). Ennek okozója az egyes pixelre eső fotonszám lecsökkenése és a molekula képének torzulása a 2D esethez képest.

A 2.3. ábra alapján látható, hogy az emissziós jel csak a minta egyik oldaláról kerül összegyüjtésre. Tehát legjobb esetben is a kibocsátott fotonok 50\%-a nem kerül begyüjtésre és a képalkotásban sem vesz részt. Adódik tehát az ötlet, hogy juttassuk vissza ezeket is a fö leképző rendszerbe. Ennek megvalósításához egy objektívből és egy tükröző elemből álló extra leképző rendszert terveztem. Mivel a mintából emittált fotonokat alulról és felülről nagy hatékonysággal terveztem összegyüjteni, ezért immerziós objektíveket terveztem használni, hogy így tegyek szert „ingyen” fotonokra. A mikroszkópban már meglévő képalkotó rendszert a megkülönböztethetőség miatt elsődleges karnak, míg a hozzáépíteni tervezett leképző rendszert másodlagos karnak fogom nevezni. A tervezési fázis során az volt a cél, hogy a meglévő mikroszkóp elrendezésen ne kelljen változtatni. Több elrendezést is szimuláltam ideális optikai elemekkel. A másodlagos kar képalkotása az egyes javasolt elrendezésekkel az 5.7. ábrán követhető végig sematikus rajzok segítségével:

(a) A legegyszerübb elrendezés, amely egy végtelenre korrigált O2 objektívből és egy M tükörből állt, nagyon érzékeny volt a beállításokra (objektív döntése és eltolása). A képalkotás sajátossága miatt ebben a verzióban az optikai tengelytől távol induló sugarak a tükörről visszaverődve nem jutottak vissza az objektívbe, ami fotonveszteséghez vezetett és a használható ROI méretét is lecsökkentette.

(b) A következő elrendezésben a végtelenre korrigált objektívet egy L2 tubuslencsével párosítottam. Az optikai tengelytől vett távolságtól továbbra is függött a begyűjthető fotonszám, és az így létrejövő kép megegyezett a tárggyal. Vagyis egy adott felvillanás fotonszámát meg lehet ily módon növelni és ez által javítani a laterális lokalizációs precizitás.

(c) Az optimális elrendezésben a tükröt egy $\mathbf{P}$ derékszögű prizmára (Porro-prizmára) cseréltem. A másodlagos kar az optikai tengelyre szimmetrikussá vált ekkor a prizma 
állása szerint. Így érve el a legkisebb fotonveszteséget és bevezetett aberrációt a három javasolt verzió közül. A továbbiakban ezért ezzel az utóbbival folytattam a munkát.
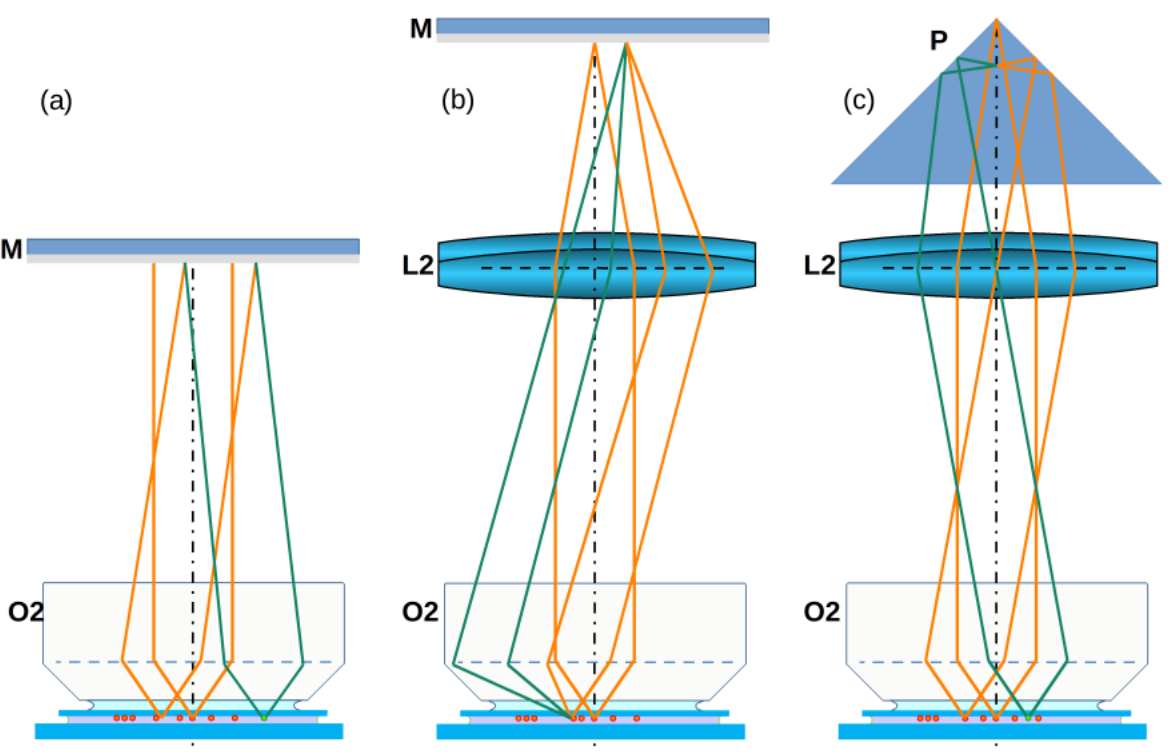

5.7. ábra. A másodlagos karra három elrendezési ötlet. (a) A csak egy tükörből (M) és objektivből (O2) álló elrendezés nagyon érzékeny a beállításokra, és az optikai tengelytől távol nagy fényveszteséggel dolgozik. (b) Egy lencsét (L2) hozzáadva a ez függés megmarad, viszont egy felvillanás fotonszáma megnövelhetö. (c) A tükröt prizmára (P) cserélve a másodlagos leképző kar egy telecentrikus rendszert alkot, a tárgy és annak képe a prizma síkjára szimmetrikusan jön létre.

\subsubsection{OSLO szimuláció}

Nyalábkövetéses módszerrel vizsgáltuk egy mesterszakos hallgatómmal közösen a másodlagos leképző kar képalkotással kapcsolatos tulajdonságait az OsLO (Optics Software for Layout and Optimization) [120] szimulációs program segítségével. Az OsLO-ban egy optikai elem felépítéséhez a következő adatokra van szükségünk:

- az elem anyaga (törésmutató, Abbe-szám határozza meg)

- a felületek egymástól vett távolsága

- a felület görbültsége 
- a felület pozíciója, melyet az OSLO alapértelmezetten az előtte lévő felülethez viszonyít

Alapértelmezett esetben a program mindig felületről-felületre követi a sugarakat és figyelembe veszi a következő felület törésmutatóját. A felületeket egymás után, szekvenciálisan kezeli a program. Megadhatunk a programban nem szekvenciális csoportokat is, melyekben bár a felületeket az előbbihez hasonló módon adható meg, azonban a nyalábkövetés szempontjából itt lényeges különbség van. A nem-szekvenciális csoportban a sugár nem törik meg sorra minden felületen, hanem mindig csak azt veszi figyelembe, aminek nekiütközött. Ezt a képfordító prizma esetén használtam fel.

A valóság pontosabb szimulációjához az 5.7. c elrendezés ideális elemeit valósakra cseréltem, de szem előtt tartottam azt, hogy csak olyat választhatok, ami a csapat leltárában rendelkezésre áll. Esetünkben két Nikon immerziós objektívet (100x és 60x) tartalmaz az elsődleges és másodlagos karból álló elrendezés. Mivel az egyes gyártók nem adják ki a pontos objektív modelljeiket vagy azok digitális sablonját, ezért ezen elemeket és a hozzájuk tartozó tubuslencséket a szabadalmaik alapján építettük meg a programban felületenként. A 60x-hoz tartozó szabadalom száma US 6,519,092 B2 és a 100x-hoz tartozó szabadalom száma $U S$ 7,046,451 B2. Az elrendezésben a tubuslencsék fókusztávolságban vannak elhelyezve az objektívektől. A mintához használt fedőlemezek BK7 üvegből készültek és $170 \mu m$ vastagságúak. Az objektívek előtt egy-egy immerziós olajréteget $\left(n=1,515 ; \Delta_{A b b e}=\right.$ $=40,7)$ definiáltunk. A megépített elrendezés a szimulációs programból kimentve az 5.8 . ábrán látható.

A két leképző kar miatt a detektoron keletkező képet is két részből, két szimulációból kell összerakni. Az elsődleges kép (ezt a továbbiakban $\mathbf{P}$-vel jelölöm) azokból a begyüjtött fotonokból áll, amelyet a 100x objektív az elsődleges karon keresztül juttat a detektorra. A másodlagos kép (ezt a továbbiakban S-sel jelölöm) azokból a korábban fel nem használt (mondhatni „ingyen”) fotonokból áll, amelyet a 60x objektív gyüjt be, kétszeresen megjárják a másodlagos kart és egy valós képet hoznak létre a mintában. A 100x objektív a számára létrehozott valós tárgyból származó fotonokat az elsődleges karon keresztül a detektorra képezi le, létrehozva a terminológiám szerint a másodlagos képet. 


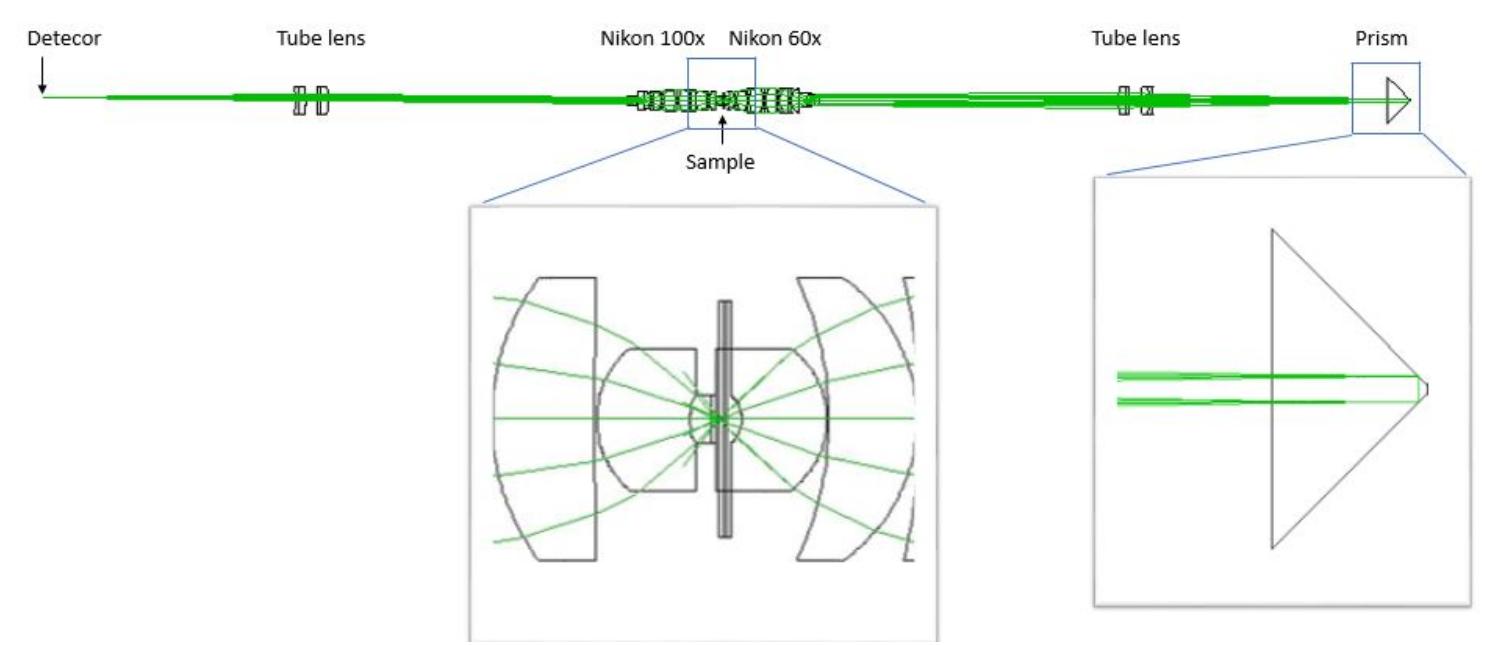

5.8. ábra. OSLO szimuláció a „c” típusú másodlagos kar képalkotásáról a kétobjektíves elrendezésben. Forrása [A1].

\subsubsection{PSF vizsgálata a leképző karokban}

A fedőlemezek által közrefogott biológiai minta (például sejttenyészet) jó közelítéssel vizes közegnek tekinthető $\approx 25$ mikron vastagsággal. A fényforrás, a pontszerü tárgy ezen szendvics belsejében található a 100x objektívtől távolabbi fedőlemez belső felületére tapadva. Mivel nem adható meg 0 érték, ezért a fedőlemezre kitapadást $1 \mathrm{~nm}$ távolságnak tekintettük. A szendvicsen belül azért ez az elrendezés került kiválasztásra, mert a leltárban lévő 60x objektív állandó fedőlemez korrekcióval rendelkezett, míg a 100x objektívvel korrigálhattam a vastag folyadékréteg által bevezetett hibát. Az elsődleges karban a fényforrásból indított sugarak először a 24,999 $\mu$ vastag vízrétegen, utána a fedőlemezen, majd az olajrétegen haladnak keresztül, eljutva végül a 100x objektívbe. Az objektívből kilépő kollimált nyalábot a tubuslencse a detektor felületére fókuszálja. Az optimális olajréteg-vastagság beállítását, a program PSF (Point Spread Function) ablakának segítségével tudtam kivitelezni, míg az $O S L O \rightarrow$ Graphics Window $\rightarrow$ PSF $\rightarrow$ Plot PSF map (Direct intergration) menüpont által generált ábra mutatja a PSF alakját és maximális intenzitását. Ha a rendszer helyes beállítása megtörtént, akkor alakja körszimmetrikus, a megfelelö olajréteg vastagság esetén a csúcsintenzitás maximális.

A másodlagos kar esetén bonyolult a helyzet, ugyanis optikai elemeit kétszer kell behelyezni a nyalábútba, valamint az elsődleges kar elemeit is újra hozzá kell adni. Ebben az 
esetben a fényforrásból a sugarak az $1 \mathrm{~nm}$ vastag vízréteg után a fedőlemezbe lépnek és az immerziós olajon keresztül összegyüjti őket a 60x objektív. Az objektívből kilépő kollimált nyalábot a tubuslencse a prizma belsejébe, annak derékszögü éléből húzott magasságvonala mentén fókuszálja. A legtöbb gyártónál a képfordító prizmák átfogóval szembeni éle le van csiszolva, így ezt a nem szekvenciális elemben egy $1 \mathrm{~mm}$ nagyságú levágással kezeltük. A prizmán belül a két teljes visszaverődés miatt a sugármenet megfordul és ugyanazokon az optikai felületeken keresztül halad vissza a mintába. Ekkor a definiálásánál is meg kell fordítani a sugármenetet és a felülethez rendelt vastagságokat is az eggyel korábbi elemhez kell rendelni. A mintában a sugármenetek egy valós képet hoznak létre a fényforrásról, de az optikai tengelyre tükrözve azt a prizma állásának megfelelően. Az elsődleges kar létrehozza a képet erről a valós tárgyról a már korábban megismert felületeken áthaladva. A másodlagos kép létrejötténél összesen három olajvastagság értéket kell beállítani a szimuláció szempontjából, amelyek közül az egyik megegyezik az elsődleges karnál kapott értékkel, míg a másik kettő össze van kapcsolva. Az optimális munkatávolság megtalálása hasonlóan történik, mint a csak elsődleges kart tartalmazó szimuláció esetében.

Miután létrejött az elsődleges- és másodlagos kép is az volt a kérdés, hogy a látótér szélén mennyire torzul a PSF. Feltételezve a rendszer szimmetriáját egy 80 mikron mérető FOV jobb-felső negyedét vizsgáltuk. A vizsgálandó pontok számát az OSLO $\rightarrow$ Surface Data $\rightarrow$ Field Points (Basic) menüpontban meg tudtam adni az xy koordinátájuk definiálásával: $x \leftarrow[0,20,40] \mu m$ és $y \leftarrow[12,26,40] \mu m$. Az y tengely mentén a prizma levágott éle miatt nem hozható létre kép, ezért el kellett tolni a koordinátákat (5.9.c ábra), hogy az elsődleges- és másodlagos képre kapott eredmények összehasonlíthatóak legyenenek. A Graphics Window $\rightarrow$ PSF vs All field points funkció segítségével megkaptam a részletes ábrát, melynek pixelméretét az EMCCD detektoréval megegyező 16 mikronra választottam. A kapott szimulációs eredmények az 5.9.a-b ábrákon láthatóak. Megállapítható, hogy az optikai tengelytől távolodva a PSF nem torzul, szimmetriáját megőrzi.

Kvantitatív módon elemezve az egyes PSF-eket 2D Gauss függvényt illesztettem rájuk, hogy megkapjam a $W_{x}$ és $W_{x}$ félérték szélességeket, amiből ellipticitást számoltam az 5.1 . képlet alapján.

$$
\epsilon= \begin{cases}W_{x} / W_{y}-1, & \text { ha } W_{x}>W_{y} \\ -W_{y} / W_{x}+1, & \text { különben }\end{cases}
$$



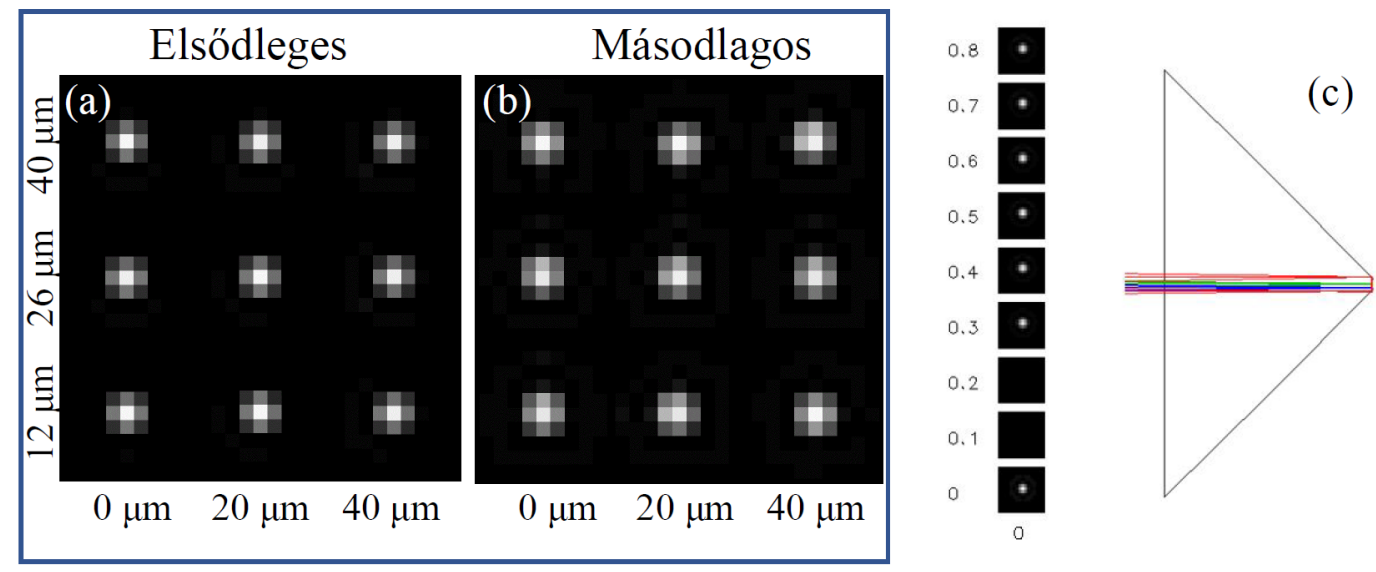

5.9. ábra. OSLO szimuláció az elsődleges (a) és a másodlagos (b) karok által létrehozott $\boldsymbol{P S F}$-ekröl a kétobjektíves elrendezésben. A levágott élü képfordító prizma csak a $45^{\circ}$-os felületeken visszaverődő sugarakat veri vissza (c). Forrása [A1].

A kapott ellipticitás értékek alapján a torzulás mindkét kép esetén kisebb volt, mint $2 \%$. Egyedüli eltérés az volt, hogy a másodlagos képen a PSF mérete 15\%-kal nagyobb volt, mint az elsődleges képen. Az elsődleges PSF, ahogy az várható is volt, alakra nem módosul. Az intenzitásértékek kinyeréséhez trükkökhöz kell folyamodni, ugyanis az OsLO-ban koordinátánként kell kiolvasni az intenzitásértékek maximumát. Az optikai tengelyhez legközelebbi PSF-re mért intenzitásértékre normáltam a többi értéket. Az elsődleges képen hibahatáron belül az eltérés kisebb mint $<1 \%$, míg a másodlagos képen az optikai tengelytől legtávolabb az eltérés $\approx 11 \%$.

Ezek a kapott értékek eleget tesznek a dSTORM méréshez szükséges alaki és intenzitáseloszlási feltételeknek. A másodlagos leképző karral kapcsolatos modellek és szimulációk nagyon hasznosnak bizonyultak, ugyanis a megvalósítás során (5.3. alfejezet) segítettek megtalálni azt az optimális elrendezést, amivel a lehető legjobb eredmény érhető el.

\subsubsection{PSF vizsgálata $3 \mathrm{D}$ megvalósításhoz}

Eddig a PSF-et csak a fókuszsíkban vizsgáltam, azonban azt is ellenőrizni kell, hogy a fókuszsíktól távolodva milyen aberrációk jelenek meg azon a képen, aminek létrehozásában a másodlagos kar is szerepet játszik. Az OsLo lehetőséget ad arra, hogy egy kontúr térképet készítsünk a PSF-ről, ez a funkció az Evaluate $\rightarrow$ Spread Function $\rightarrow$ Create Contour Grid menüpontban található. Beállítható az a sík, amire a vetületet szeretnénk képezni (például 
yz). Majd a beállítások után a Text ablakban megjelennek a PSF fóbb adatai: maximumés minimum intenzitások, és azok pozíciója a síkban. Az intenzitás eloszlás ábrázolható a Evaluate $\rightarrow$ Spread Function $\rightarrow$ Plot Contours menüpontban. A kontúr létrehozásánál az OSLO optikai koordinátákat használ, melyek a következő képlettel számolhatók:

$$
\begin{aligned}
& u=\frac{2 \pi}{\lambda} \cdot N A^{2} \cdot z \\
& v=\frac{2 \pi}{\lambda} \cdot N A \cdot \sqrt{x^{2}+y^{2}}
\end{aligned}
$$

Az elsődleges és másodlagos képek optikai tengelyen lévő PSF-jeinek yz síkbeli rajzolata az 5.10, ábrán látható. Azonnal észrevehető, és egyben várt eredmény is a másodlagos kép axiális méretének elnyúltsága az elsődlegeshez képest és a szférikus hiba a szendvicsen belüli folyadékréteg vastagsága miatt.
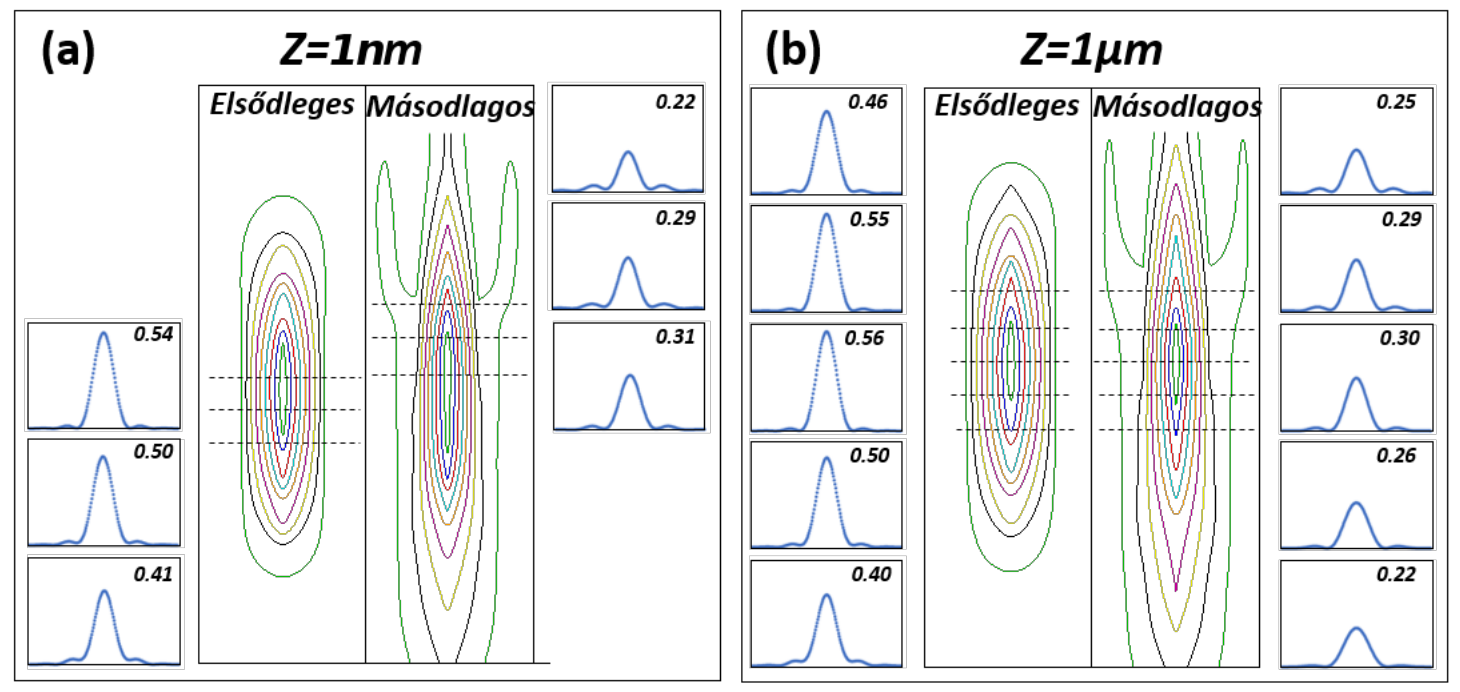

5.10. ábra. Az elsődleges és másodlagos karokban keletkező $\boldsymbol{P S F}$-ek kontúr képei különböző mintamélységek esetén. A minta koordináta-rendszerében $150 \mathrm{~nm}$ távolságokra keresztmetszeti képek készültek az objektív DOF-ján belül. Az egyes keresztmetszeti képekre a Strehl-arány került meghatározásra. Forrása [A1].

Egy biológiai minta vastagsága a pár mikron nagyságrendjébe esik, ezért szükséges a PSF-et úgy is vizsgálni, ha a forrás a felső fedőlemeztől $1 \mathrm{~nm}, 1 \mu \mathrm{m}, 2 \mu \mathrm{m}$, és $4 \mu m$ távolságokra helyezkedik el. A korábban említett 5.10 . ábrán csak az első két értéket ábrázoltam. Ezen felül arra is kíváncsi voltam, hogy kontúr képeken az egyes keresztmetszetek hogyan 
néznek ki (ha ott lenne a fókuszsík). A keresztmetszeteket kék vonallal jelöltem és a minta koordináta-rendszerében egymástól 150 $\mathrm{nm}$ távolságra helyezkednek el. A keresztmetszeti képeket az OSLO nem készíti el, azonban egy saját függvénnyel kinyerhetőek a PSF mátrixából a megfelelő értékei. A $Z=0 \mu m$ értéknél (5.10,a ábra) azért van csak három-három keresztmetszeti kép, mert a minta a fedőlemez közelében volt.

Az elsődleges képhez képest a másodlagoson felére csökken a szimuláció által megadott Strehl-arány. A Strehl-arány alacsony értéke a szimulációban a sok felület hullámfront torzítása miatt következik be, ami az elsődleges képet is érinti, nem csak a másodlagosat. Az intenzitás csökkenéstől eltekintve a PSF továbbra is szimmetrikus, tehát a javasolt „c" elrendezésű másodlagos kar alkalmas SMLM mérésekre az objektívek DOF-ján belül. Mondhatni nem maradt más hátra, mint realizálni a szimulált elrendezést és valós mérésekkel is alátámasztani a kapott eredményeket.

\subsubsection{Az eredmények tézispontban megfogalmazva}

[T2]. Egy új, leképzésen alapuló, kétobjektíves, Porro-prizmás mikroszkópos elrendezést terveztem és modelleztem nyalábkövető optikai szimulációs szoftverrel. A javasolt optikai elrendezés összegyüjti a korábban képalkotásra fel nem használt fotonokat, és azt a mikroszkóp számára valós tárgyként felhasználhatóvá teszi. OSLO optikai szimulációs programban elkészítettem a két leképző kar modelljét a két kép létrejöttének szimulálásához, továbbá összevetettem a kapott pontátviteli függvényeket a fókuszsíkban és axiális vetületekben. Szimulációkkal igazoltam azt, hogy a javasolt elrendezés alkalmas egymolekula detektáláson alapuló mérésekhez.

Kapcsolódó publikációk: A1 P3-5 


\subsection{Multimodális lokalizációs mikroszkóp kivitelezése}

Ahogy azt az 5.2. alfejezetben láthattuk a szimulációkon, optikailag nincs akadálya annak, hogy egy másodlagos leképző karral a lokalizációs eljárást nem korlátozó mértékü aberrációval összegyüjtsük a mintából származó, korábban fel nem használt emissziós jelet. A szimulációk ellenőrzéséhez vizsgálni kell a rendszer megvalósíthatóságát, használhatóságát és az elért javulásokat is a javasolt másodlagos kar megépítésével. Az alábbi fejezetben ezért tárgyalom a felépített rendszer beállítási protokollját és összehasonlítom az szimulációból kapott PSF-et a fluoreszcens gyöngyökre kapott eredményekkel. Továbbá értelmezem a modalitásokat a másodlagos leképző karon, és ismertetem az adatfeldolgozás egy kulcslépését. Az egyes megvalósított modalitásokat biológiai mintákon is tesztelem ezzel támasztva alá az alkalmazhatóságot.

\subsubsection{Felépítés és beállítás}

A kétobjektíves elrendezés megvalósítását az AdOptIm csoport 4 fejezetben bemutatott egyedi mikroszkópjának kiegészítésével tettem meg. A másodlagos leképző kar 3D modellje az 5.11. ábrán látható, felépítésének és beállításának lépései az alábbiakban olvasható.

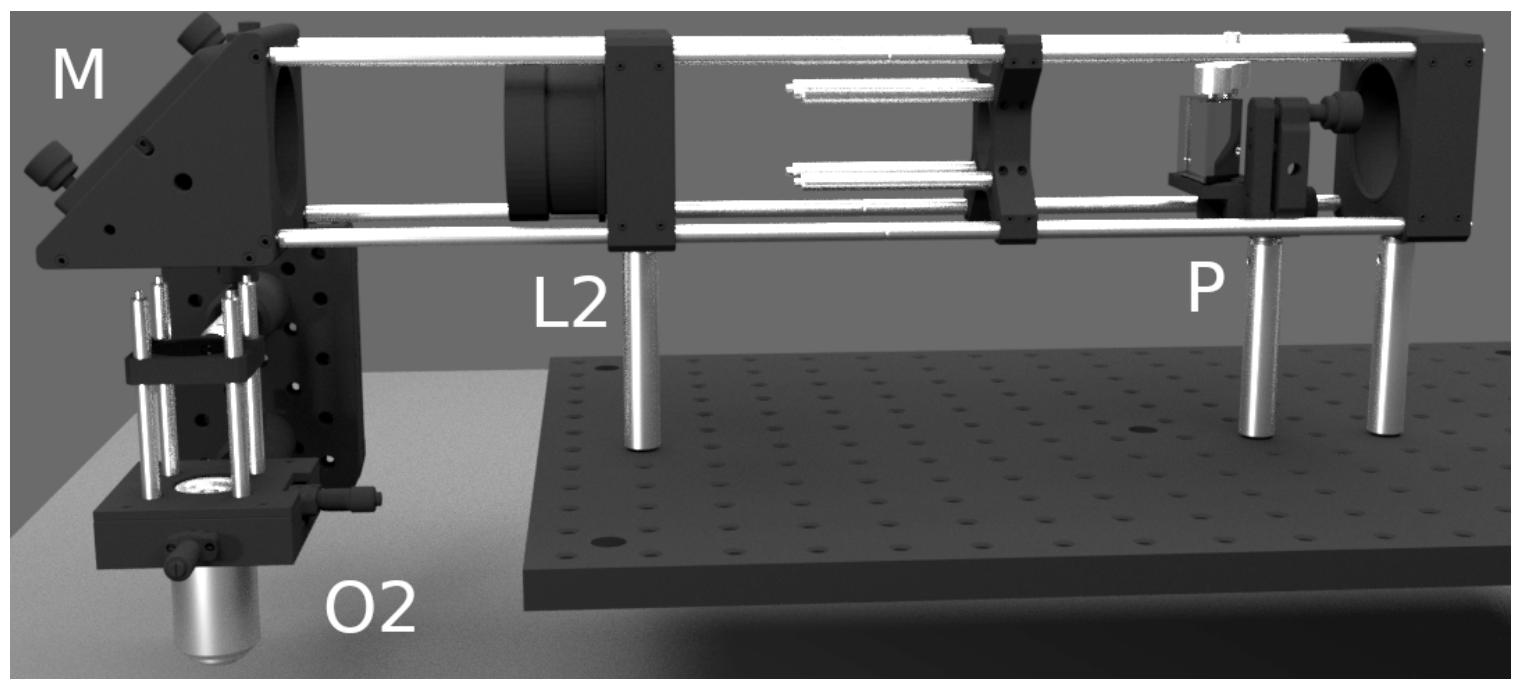

5.11. ábra. A másodlagos leképzö kar 3D modellje. Az O2 objektív által összegyüjtött fotonokat az $\boldsymbol{M}$ tükör az akromatikus dublett felé irányítja, ami a $\boldsymbol{P}$ Porro-prizmában hoz létre képet. Ezt a képet megfordítva a rendszer visszaképezi a mintába. Az L2 tubuslencse és a $\boldsymbol{P}$ prizma közé $\boldsymbol{P} \boldsymbol{S F}$ módosító elem helyezhetö be. 
A mikroszkóp vázhoz rögzítettem egy transzlációs eltolót (Thorlabs PT1/M), amelynek feladata a 60x objektív (O2) z irányú mozgatása volt. A pozíció gyors beállításához egy saját tervezésű léptetőmotoros eltolót használtam a reprodukálhatóság miatt az eltolóban lévő mikrométer csavar helyett. Ezt egy Arduino UNO alapra és a Motor Shield v1 kiegészítőre építettem, saját kóddal. Meghajtáshoz egy NEMA17 méretű bipoláris léptetőmotort használtam tengelykapcsolóval, ami egy beállító csavart (Thorlabs F25ST200) forgatott egy adapterben (Thorlabs F25SSA1). A megépített léptetőmotoros eltoló az 5.12 ábrán látható. $400 \mathrm{~nm}$ volt $3 \mathrm{~cm}$-en az a legkisebb lépésköz amit az eltolóval el tudtam érni reprodukálhatóan felezett lépésközű módban. Az Arduino vezérlése egy saját, eseményvezérelt LABVIEW (National Instruments) kezelőfelületen történt [S2], ami bárki számára elérhető és szabadon használható.



5.12. ábra. A lineáris eltoló mozgatásához épített léptetőmotoros aktuátor és Arduino vezérlöje. A kezelöfelület az [S2] oldalon érhetö el.

1,5" átmérőjü oszlopokra rögzítettem egy furatos alumínium lapot (Thorlabs MB4560/M) a másodlagos leképző kar nem mozgó elemeinek. Az elemek stabil rögzítéséhez egy sínrendszert használtam (5.11 ábra), amelynek elején, a mikroszkópváz felett, egy 45-ban megdöntött (Thorlabs KCB2C/M) 2"-es tükör (M, Thorlabs BB2-E02) volt. A tükör és a sínrendszer beállítását a gerjesztő lézernyaláb segítségével tettem meg objektívek nélkül. Az objektív hátsó fókuszának helyétől $250 \mathrm{~mm}$-re egy $250 \mathrm{~mm}$ fókusztávolságra akromatikus dublett lencsét (L2, Thorlabs AC508-250-A-ML) helyeztem. A tubuslencse helyett azért használtam nagyobb fókusztávolságú lencsét, hogy másodlagos kar nagyítását megnöveljem, ez által csökkentve a prizma levágott éle miatt nem kihasználható területet. A lencsétől újabb $250 \mathrm{~mm}$ távolságra helyeztem el a képfordító prizmát (P, Thorlabs PS908H-A). A prizma beállítására a visszavert lézernyalábot használtam fel, hiszen an- 
nak a gerjesztő lézernyalábbal megegyezó úton kell haladnia.

Ezek után következett a finomhangolás az objektívek behelyezésével és az egyes optikai elemek pozíciójának és döntöttségének állításával úgy, hogy a visszavert nyalábút megegyezzen a gerjesztő nyalábúttal. Az objektív xy pozícióját a gerjesztő lézer által meghatározott tengely szerint állítottam be. Végezetül egy teszt mintát (100nm-es fluoreszcens gyöngyök fedőlemezen) helyeztem a rendszerbe. Az O1 objektívvel, a normális használattal megegyezően, élesre álltam és bekapcsoltam a PFS fókusztartó funkciót. Míg O2 mintára állása a léptetőmotoros vezérlővel történt. Bekapcsolva a kamera képet, valamint a megjelenítés dinamikus tartományát kiterjesztve, a gerjesztő lézer foltját láthatóvá tettem a számítógép kijelzőjén. Kihasználva ezt foltot folytattam a leképző rendszer finomhangolását. O2 z pozíciójának mintához való további közelítésével egy második lézerfolt is megjelenik a detektor-képen. Az volt a kitüzött cél, hogy z irányú mozgatás mellett a második folt ne mozogjon xy síkban. Apró lépésközzel tovább közelítve O2-t egy sötét sáv jelenik meg a képen (P prizma éle) és erre tükrözve a minta képe. Erről legegyszerúbben a minta laterális mozgatásával lehetett meggyőződni, ugyanis a tükrözött tengely szerint a másodlagos kép ellentétes irányba mozog. A prizma élét a detektorkép közepére kell állítani, valamint a megvilágított terület lecsökkentéséhez egy apertúrát (borotva éle) kell behelyezni a gerjesztő nyalábba, a minta konjugált síkjának helyén.

A PSF alakjára vonatkozó finomhangolás ez után következhetett. A pontátviteli függvény szimmetriáját és a hibás beállítás következtében bevezetett aberrációkat legegyszerübben a fókuszsík alatt és felett lehetett ellenőrizni. Mivel a kétobjektíves rendszert több mint egy éven át használtam mérésekhez és fejlesztésekhez ezért ennyi idő alatt elkerülhetetlen, hogy bizonyos beállított elemek elmozduljanak, vagy rosszul kerüljenek visszahelyezésre. A jelenlegi konstrukció szabadsági fokainak száma miatt követni kellett a lehetséges hibaforrásokat. Az O2 objektív döntöttségére utalt a másodlagos kép elmozdulása z pozíció állítása esetén. Ennek a jelenségnek a korrekciójához vezetni kellett azt, hogy az optikai elemek megdöntéséhez melyik mikrométer csavart mennyivel fordítottam el és milyen eredményt kaptam. Ha O2 objektív tengelye nem a másodlagos kar $\mathbf{P}$ prizma által kijelölt optikai tengelyén volt, akkor az fotonveszteséget eredményezett, valamint nagyobb hiba esetén a másodlagos képen PSF-ek xy szimmetriája is elromlott. Ezt a hibát a prizma megdöntésével, illetve az objektív xy eltolásával lehetett korrigálni. 
A hibák közül látványos volt a rosszul beállított O2-L2 távolság, amit szerencsére csak átépítések során tapasztalhattam meg. Ekkor a másodlagos képen a középpontól kifelé haladva a fluoreszcens gyöngyök elnyúlttá váltak és ez a hiba a középpontra szimmetrikus volt. A vignettázás korrekciója természetesen a másodlagos karon belüli távolságok ellenőrzésében merült ki.

Hogy a kétobjektíves rendszerben vizsgálható legyen a minta, azt két 0,17 $\mu m$ vastag fedőlemez közé kellett helyezni, amelyek egy $2 \mathrm{~cm}$ átmérővel átfúrt alumínium laphoz voltak ragasztva (5.13. ábra) a stabilitás miatt. Voltak próbálkozások csak fedőlemezes rögzítésre, de azok immerzió miatti meghajlása elkerülhetetlen volt és így ez az irány elvetésre is került. A két fedőlemez távolságát a használt folyadékmennyiség alacsonyan tartásával $(\approx 25 \mu \mathrm{m})$ minimális volt a bevezetett szférikus hiba. A minta z irányú mozgatása ezek után már csak a piezo eltolóval történt, hogy a két objektív közötti távolság állandó maradjon.

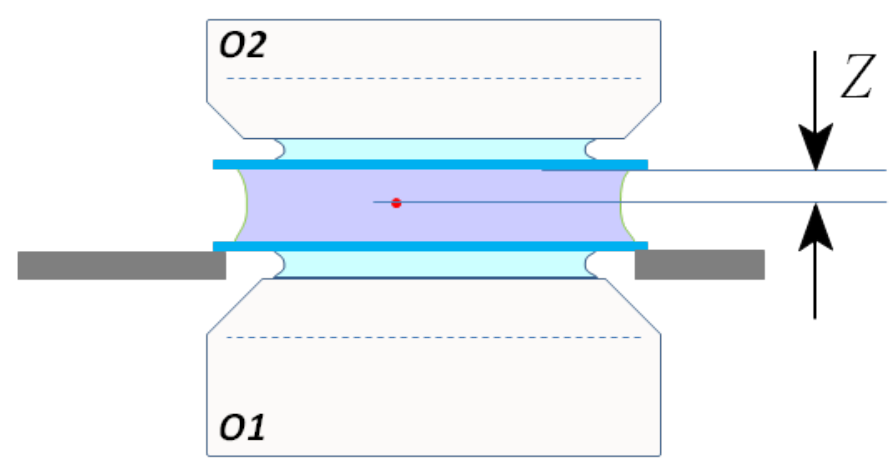

5.13. ábra. Az $\mathbf{O} \mathbf{1}$ objektív-immerziós olaj-fedőlemez-minta-fedőlemez-immerziós olajO2 objektív szendvics a mintatartón. A mintát az felső fedőlemezhez rögzítettük, ahonnan a $\boldsymbol{Z}$ távolságot is mértük. Forrása [A1].

A kétobjektíves elrendezésben, a szimulált modellel megegyezően a 60x objektívhez közelebbi fedőlemezen volt a minta, mivel az egy állandó, 0,17 értékű fedőlemez korrekcióval rendelkezett, valamint képsík korrigált is volt. A 100x objektív változtatható fedőlemez korrekciójával a vékony folyadék réteg okozta hibákat korrigálni lehetett, amennyiben ilyenre szükség volt. A beállításhoz méréseket készítettem $100 \mathrm{~nm}$ átmérőjű fluoreszcens gyöngyökről és azok másodlagos képeiről (5.14. ábra). A szimulációval megegyező eredményeket kaptam, ami a megépített konstrukció helyes beállítására utalt. 
(a) Elsődleges

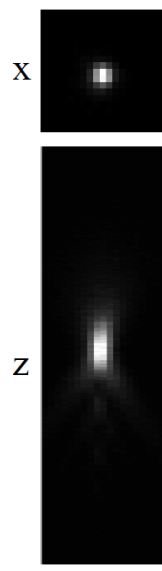

$\mathrm{y}$ (b) Másodlagos



5.14. ábra. Fluoreszcens gyöngyök elsődleges és másodlagos képeinek kísérletileg mért intenzitás eloszlás térképe. Az OSLO szimulációs eredményekkel jó egyezést mutatnak. A pixel méret 160nm. Forrása [A1].

Ami azonban problémaként jelentkezett, és a másodlagos képen is látható, az ott mért intenzitás tipikusan csak a fele volt annak, mint amit az elsődleges képen mértem. Ennek a veszteségnek a legfőbb oka az emittált fénynek az O2 objektíven történő kétszeres keresztülhaladása, hiába volt minden optikai elem antireflexiós réteggel bevonva. Az objektívre kimért transzmisszió $T_{647 n m}=81 \%$ és $T_{561 n m}=84 \%$ volt. Olyan szempontból viszont megkerülhető volt a probléma, hogy az elsődleges képből kerültek meghatározásra az xy koordináták. A másodlagos képből a modalitáshoz szükséges információ kinyerése történt.

\subsubsection{Képalkotás és adatfeldolgozás}

Az előző alfejezetben felépített és pontosan beállított prizmás-kétobjektíves mikroszkóp képalkotásának sematikus modellje az 5.15.a ábrán látható. A gerjesztő fény a ROI felét világítja ki a minta konjugált síkjába helyezett Ap penge kitakarása miatt. Erről a területről O1 és O2 objektívek gyüjtik össze az emittált fotonokat. Az utóbbi az L2 tubuslencsén keresztül képet hoz létre a $\mathbf{P}$ képfordító prizmában. Ezt a képet a tubuslencse és az O2 objektív leképzi a mintába a kivilágítatlan területre. A meglévő mikroszkóp rendszer létrehozza az elsődleges képet (fekete sugarak) és a megfordított tárgyból a má- 
sodlagos képet (kék sugarak). Egy fluoreszcens gyöngyökről létrehozott $\mathbf{P}$ elsődleges- és S másodlagos kép az 5.15.c ábrán látható. Mivel a másodlagos leképző kar optikai elemei szabadon elérhetőek, ezért a mintából összegyüjtött emittált fényt szabadon lehet módosítani egyszerüen behelyezhető optikai elemekkel. Az 5.15.b ábrán a hengerlencse (i), a polarizátor (ii) és az emissziós szűrő (iii) került feltüntetésre, mint módosító elem. Ezek a módosítások csak a másodlagos képre alkalmazódnak, az eredeti, elsődleges képet nem befolyásolják. A megvalósított modalitásokat a következő alfejezetben fejtem ki.

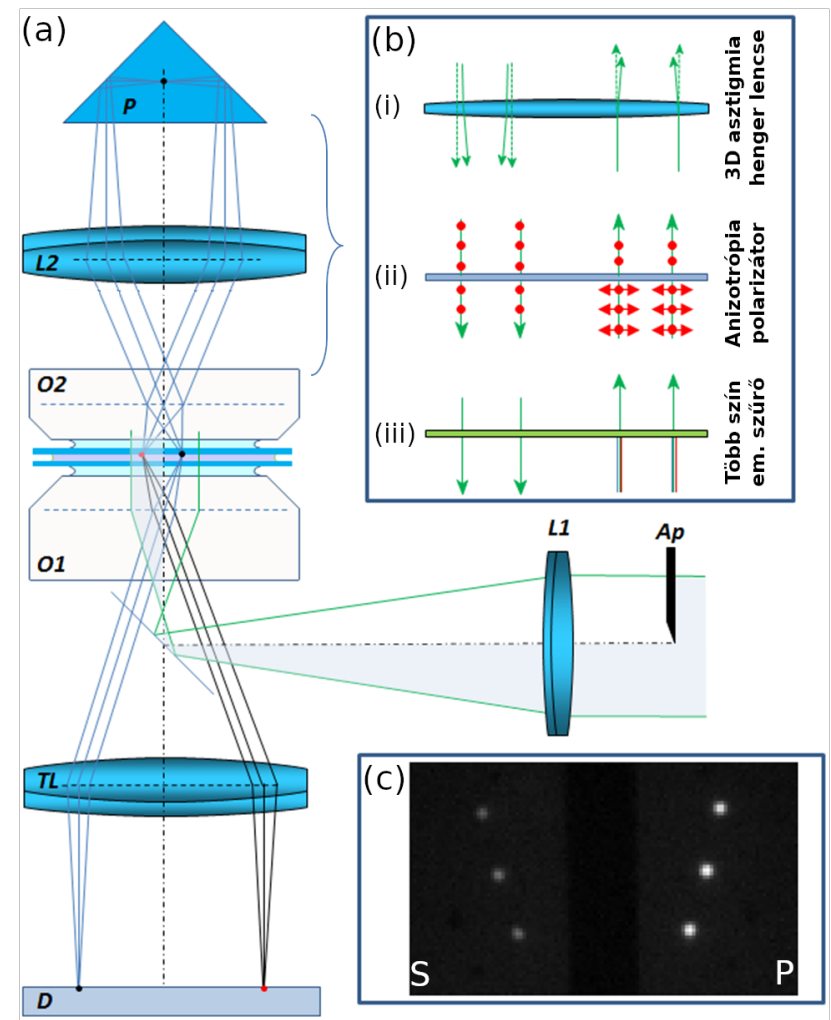

5.15. ábra. A prizmás kétobjektíves elrendezésben a modalitások csak a másodlagos leképzö karban kerülnek alkalmazásra megörizve az eredeti, elsődleges képen elérhetö lokalizációs precizitást (a). Az egyes modalitások megvalósitását a (b) ábrarészlet mutatja. A rendszerben egy fluoreszcens gyöngyökröl készült képet modalitások alkalmazása nélkül a (c) ábrarészlet mutatja. Az intenzitás különbséget az optikai elemeken történő többszörös keresztülhaladás okozza. Forrása [A1].

Az elsődleges- és másodlagos kép adatainak összekapcsolása egy párkereső algoritmussal történik. A detektált kapcsolási események síkbéli $\mathbf{X}$ és $\mathbf{Y}$ koordinátáira tükrözött vagy nem tükrözött koordinátaként hivatkozok aszerint, hogy a képfordítás hogyan hat 
az egyes tengelyekre. Feltételezve a másodlagos kar pontos beállítottságát (a prizma éle centrált, az elsődleges és másodlagos képek nem tartalmaznak forgatást vagy nyírást) a következő két állítást lehet tenni :

I. A tükrözött koordináták $\left(X, X^{\prime}\right)$ összege konstans, és megadja a kép méretét.

II. A nem tükrözött koordináták $\left(Y, Y^{\prime}\right)$ különbsége nulla.

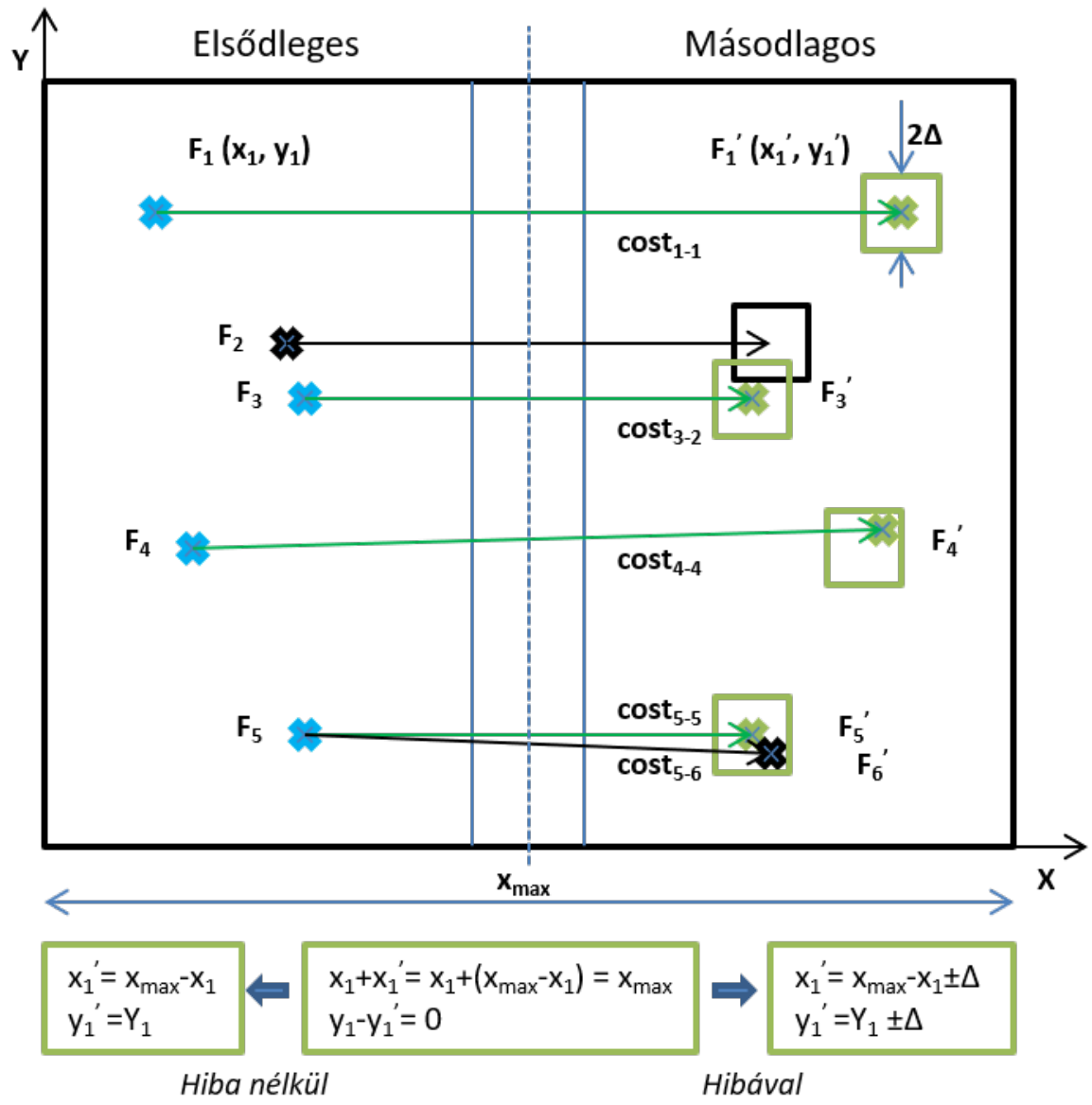

5.16. ábra. Döntési és kiválasztási szabályok a párositás során: $F_{1}-F_{1}^{\prime}$ egy tökéletes pár; $F_{2}$-höz nem rendelhetö pár az elfogadási ablakon belül, tehát elvetésre kerül; $F_{3}-F_{3}^{\prime}$ ugyancsak egy tökéletes pár; az $F_{4}-F_{4}^{\prime}$ pár is elfogadásra kerül, mert a másodlagos kép az elfogadási ablakon belül található; $F_{5}-F_{5}^{\prime}$ elfogadásra kerül, míg $F_{5}-F_{6}^{\prime}$ elvetésre a magasabb párosítási költség miatt. Forrása [A1].

Felhasználva ezt a két állítást, és megengedve egy kis méretű hibát, a párosítás elvégezhető 5.16, ábra) az alábbi lépéseket követve egy ismeretlen esetre: 
I. A tükrözött koordináták szélső értékeiből megbecsülhető a ROI mérete.

II. A képkockák első 10\%-ra meg kell határozni az összes lehetséges $(n(n-1) / 2)$ párosításra vonatkozóan a tükrözött koordináták összegeit és a nem tükrözött koordináták különbségeit.

III. Hisztogramon ábrázolva az előbbi lépésben kapott értékeket maximum elemszámot keresve megkaphatjuk a felvételre jellemző összeg értéket.

IV. Ezek után a teljes mérésre elvégezhető a párosítás, az összeg értékekből kiszámítva az elméleti pozíciót és a megadott elfogadási hibahatárt $\Delta$.

V. Hozzárendelve egy párosítás költségét (a $\operatorname{cost}_{p-s}$ értékét az kiszámolt koordinátától pixelben vett eltérés négyzeteként határoztam meg) az egyes párba rendezett koordinátához, az adott elfogadási területen belül a legolcsóbb kerül kiválasztásra, míg a többi elvetésre.

\subsubsection{Mérési eredmények}

Hogy bizonyítsam a kétobjektíves rendszer használhatóságát teszt mintákkal és valós, biológiai mintákkal teszteltem az elrendezést. A legegyszerúbb minta a fedőlemezre polyL-lysine-nel kikötött 100nm-es fluoreszcens gyöngyök voltak. Biológiai minták közül a phalloidin-AF647-tel jelölt aktin filamentumok voltak az egyszerűbbek, amelyek bár 2D struktúrába rendeződnek, lokalizációs szempontból mégis jól kezelhetőek. Végeztem méréseket mikrotubulus jelölt Schneider 2 sejttenyészeten (AF647) is. Bonyolultabb biológiai minta volt azonban a muslica miofibrillum preparátumok. Ezekben ugyanis a feloldás alatti kettős vonalak meghatározhatósága jó értékmérőnek mutatkozott és ellenőrizhető is volt, valamint 3D struktúrát is mutattak ezek a preparátumok (részletesebben az 5.4 . alfejezetben). Az utóbbi minta jelölésénél többféle immunhisztokémiás jelölést is kipróbáltunk (sals, kettinIg16, tropomodulin). A dSTORM mérésekhez a másodlagos antitestek AF647-tel voltak konjugálva.

A kétobjektíves rendszerben a következő modalitásokat valósítottam meg:

3D bi-plane modalitás • Megvalósítás szempontjából ez tekinthető a legegyszerűbbnek, mert ehhez a modalitáshoz nem szükséges további optikai elem használata a másodlagos leképző karban. Elegendő csupán az O2 objektívet egy másik síkra állítani, hogy a 
kétsíkú leképzéshez megfelelőek legyenek a feltételek. Hasonló eredmények érhetőek el az L2 tubuslencse és a $\mathbf{P}$ prizma távolságának módosításával is. A nyers felvételek feldolgozása során, hasonlóan a bevezetőben tárgyalt modalitásnál, egy eseménypár egyes képeihez hozzárendelhető a $W_{A}=W_{P}$ és $W_{B}=W_{S}$ jelölés. A problémát tehát vissza lehet vezetni a nyalábosztóval megvalósított bi-plane esetre, vagyis az ott használatos algoritmusok és megoldások ugyanúgy alkalmazhatóak. A kalibrációs függvényt kell egyedül elkészíteni a rendszerre. A két $W$ érték kapcsolatának leírására a korábban használt 5.1 . függvényt használtam. Az x-y koordináták az elsődleges (P) képből kaphatóak meg, míg a z koordináta a kalibrációs függvény alapján a félértékszélességekből. Ezen utóbbi elkészítéséhez érdemes olyan fedőlemezt használni, amelyen a minta mellett fluoreszcens gyöngyök is találhatóak, így a kalibráció elvégezhető ugyanazon beállításokkal.

Itt most csak a legnehezebb mintát, a tropomodulinnal jelölt szarkomer preparátumot tárgyalom. Ezekhez a dSTORM mérésekhez tipikusan 30000 képkockát vettem fel 20 - 30ms expozíciós idővel. Vegyük észre, hogy a kétobjektíves elrendezésben a felvételkészítés ideje is a tipikus 15-20 perces dSTORM felvétel időtartamába esik. A rendszer stabilitásával nem voltak gondok. A gerjesztéshez 647nm-es lézert használtam HILO megvilágítás mellett. Az egyes objektívek fókuszsíkjai között 350nm volt a különbség, amelyet a mérések elején ellenőriztem és piezo eltoló segítségével állítottam be. A felvételsorozatból egy kiragadott képkocka látható az 5.17.a ábrán, ahol látható az egyes kapcsolási események képeinek szimmetriája, valamint az eltérő fókuszsíkok miatt bekövetkezett méretváltozása. Az elsődleges képből rekonstruált 2D szuperrezolúciós kép látható az 5.17.b ábrán, kiemelve a kilencedik H-zóna kettős vonalát. A kettő vonal távolságát $\approx 125 \mathrm{~nm}$-nek mértem. A hengerszimmetrikus izomszál 3D rekonstrukcióját a párosított másodlagos képből származó adatokat felhasználva készítettem el. Két keresztmetszeti kép látható az 5.17.c-d ábrán, amelyen a megjelenített síkok 183nm távolságra van egymástól. Az izomszál szélességét az egyes keresztmetszeti képeken piros szaggatott vonallal jelöltem, a rétegek elhelyezkedése az 5.17.e sematikus ábrán látható. A 4. H-zóna oldalnézeti képe az 5.17.f ábrán látható, amelyre egy 800 nm sugarú korong illeszthető.

A párkereséshez a $\leq 50 \mathrm{~nm}$ laterális precizitású lokalizációk kerültek felhasználásra, amely szürési paraméter egyszerre volt érvényes az elsődleges- és másodlagos képre is. A végső szuperrezolúciós képek elkészítéséhez, a párosítás után a $\leq 25 \mathrm{~nm}$ precizitás szűrő 

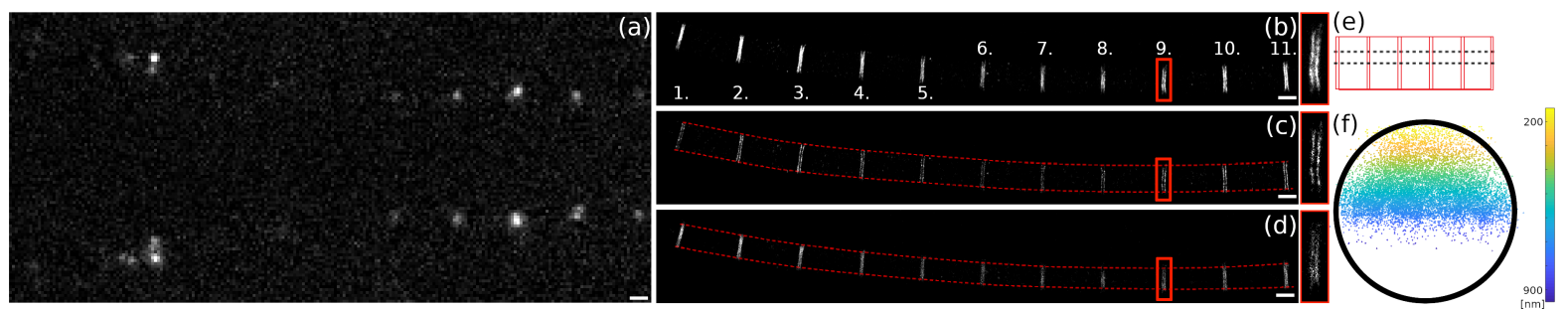

5.17. ábra. A 3D bi-plane modalitás muslica indirekt repülöizom mintán demonstrálva. Az elsődleges (felső) és másodlagos (alsó) képen látható az egyes felvillanásokhoz tartozó $\boldsymbol{P S F - e k ~ m e ́ r e t ~ k u ̈ l o ̈ n b s e ́ g e ~ ( a ) . ~ A ~ 2 D ~ s z u p e r r e z o l u ́ c i o ́ s ~ ( b ) ~ e ́ s ~ a ~ 3 D ~ r e k o n s t r u k c i o ́ b o ́ l ~ k i v a ́ - ~}$ gott szekciók $(\boldsymbol{c}, \boldsymbol{d})$ jól mutatják a Tropomodulin fehérje elrendeződését a H-zónában. A 9. zóna oldalnézeti képe mutatja a várt korong alakot $\approx 800 \mathrm{~nm}$ méretü sugárral. A skála 1 mikront jelöl. Forrása [A1].

került beállításra (amely megegyezik a szakromer mintáknál használt szüréssel). A kiszámolt mintára vett laterális feloldás a 2.10 képlet szerint: 30,91nm. Ezen érték a 2.3 táblázat alapján egy tipikus 2D és az ez alapján optimális feltételek mellett becsült 3D bi-plane között található.

3D asztigmatizmus modalitás • A modalitás megvalósításához egy 4000mm fókusztávolságú hengerlencse (Comar 4000 Y 25) került behelyezésre a másodlagos karba L2 lencse és $\mathbf{P}$ prizma közé. A bevezetett, lencsepozíciótól függő asztigmatizmus meghatározására csapatunk egyik hallgatója készített egy mátrix optikával számoló LabView programot [S6], amely használatával meg lehetett határozni az optimális PSF módosítást. A mérésekhez a 95mm-es prizmától mért távolságot használtam. Kísérletileg is ellenőriztem a szimulációt, fluoreszcens gyöngyökre meghatároztam a rájuk illeszthető Gauss-függvények félérték szélességeit, a kapott értékek az 5.18.a ábrán láthatóak. Az ebből számolt kalibrációs görbe az 5.18,b ábrán tekinthető meg. Minél meredekebb a kalibrációs görbe lineáris szakasza, annál jobb z feloldást lehet elérni, viszont a feloldható rétegvastagság lecsökken (5.18,c ábra).

Az eseménypár elsődleges képeiből meghatározható az xy koordináta, míg a másodlagos képre illesztett Gauss-függvény $W_{x}$ és $W_{y}$ értékeiből megkapható az ellipticitás az 5.1 . függvény alapján. A fluoreszcens gyöngyökre felvett kalibrációból visszaszámolható az adott ellipticitáshoz tartozó z pozíció. Mivel a harmadik koordináta nem függ a két objektív távolságától, így nem szükséges ugyanazon mintán elvégezni a kalibrációt, mint 

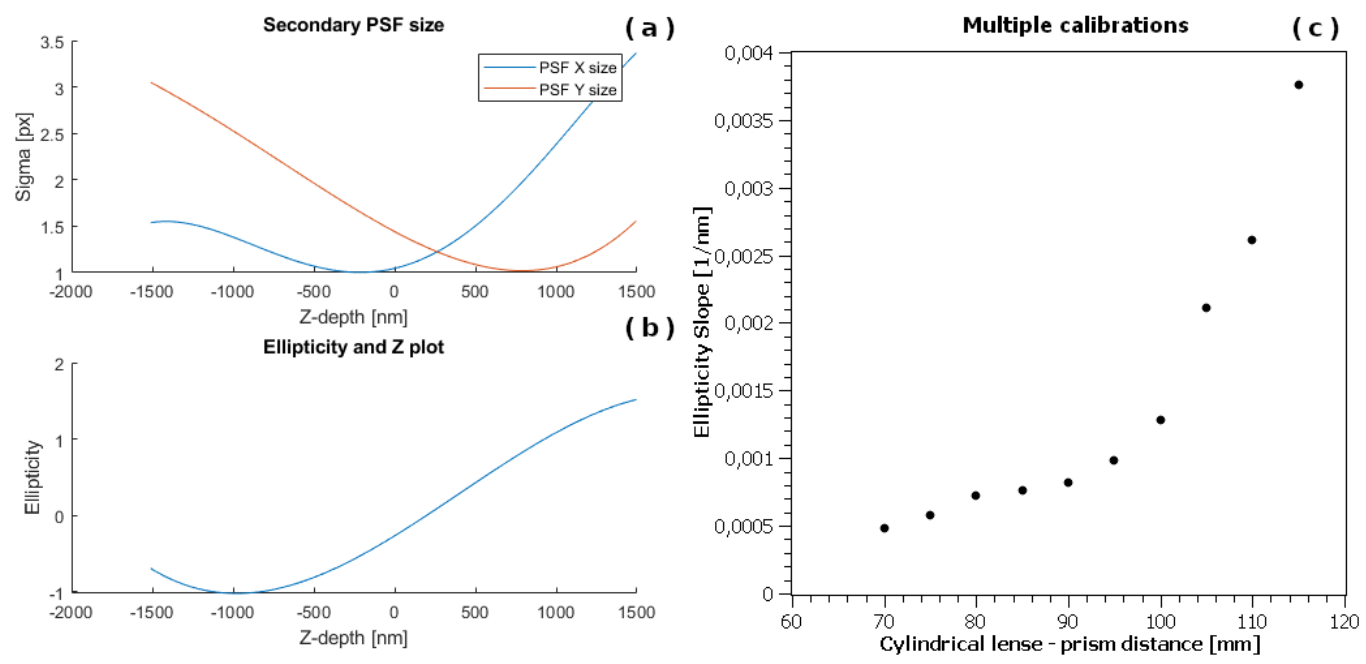

5.18. ábra. Flureszcens gyöngyökre meghatározott kalibrációs görbe 95mm-es prizmalencse távolság esetén $(a, b)$. A kiszámolt ellipticitások meredekségét a prizma-lencse távolság függvényében a (c) ábra mutatja. Forrása [A1].

amit mérni akarunk. Hasonlóan a bi-plane esethez, itt is csak a tropomodulin-AF647 jelölt miofibrillumos mintán végzett mérést mutatom be az 5.19, ábrán. A hengerlencsét leszámítva a felvételkészítés módja megegyezett a korábban bemutatott modalitásnál bemutatottakkal.
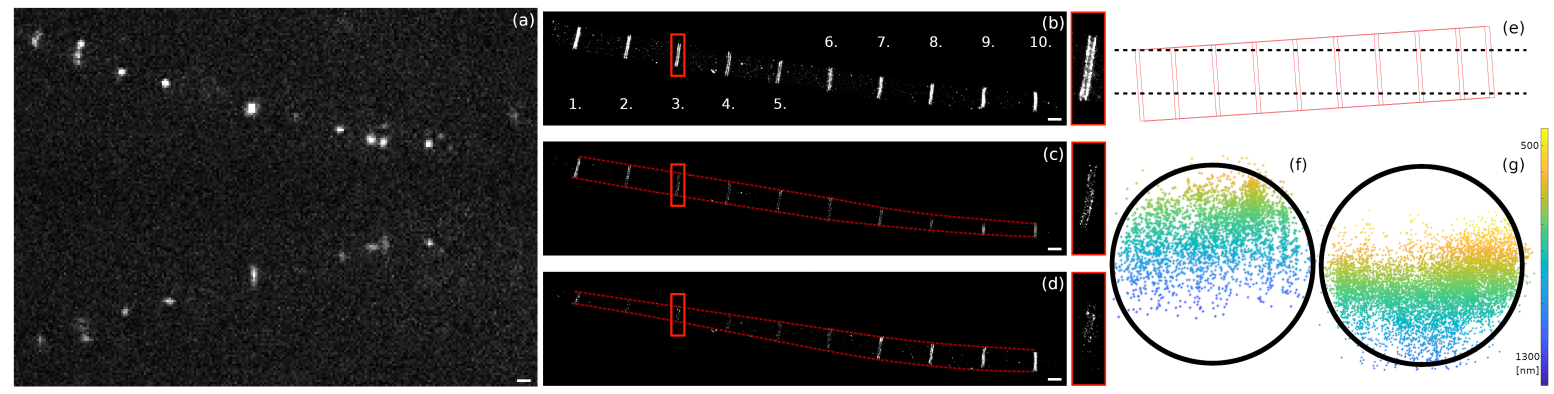

5.19. ábra. A 3D asztigmatizmus modalitás muslica indirekt repülöizom mintán demonstrálva. Az másodlagos képen látható az egyes felvillanásokhoz tartozó $\boldsymbol{P} \boldsymbol{S F}$-ek elliptikussága (a). A 2D szuperrezolúciós (b) és a 3D rekonstrukcióból kivágott szekciók $(\boldsymbol{c}, \boldsymbol{d})$ jól mutatják a Tropomodulin fehérje elrendeződését a H-zónában. A 3. és 8. zóna oldalnézeti képei mutatják a várt korong alakot $\approx 800 \mathrm{~nm}$ méretü sugárral. A skála 1 mikront jelöl.

A felvételsorozatból egy kiragadott képkocka látható az 5.19.a ábrán, ahol látható az alsó, másodlagos képen a pontátviteli függvény elliptikussága. Az elsődleges képből 
rekonstruált 2D szuperrezolúciós kép látható az 5.19.b ábrán, kiemelve a harmadik Hzóna kettős vonalát. A hengerszimmetrikus izomszál 3D rekonstrukcióját a párosított másodlagos képből származó adatokat felhasználva készítettem el. Két keresztmetszeti kép látható az 5.19 . c-d ábrán, amelyek a $915 \mathrm{~nm}$ és $685 \mathrm{~nm}$ központú egyenként $\approx 46 \mathrm{~nm}$ vastag rétegekhez tartoznak. A megdöntött izomszál szélességét az egyes keresztmetszeti képeken piros szaggatott vonallal jelöltem, jól látható az ahogy a szál keresztülhalad DOF-on. A rétegek elhelyezkedése az 5.17.e sematikus ábrán látható. A 3. és 8. H-zóna oldalnézeti képei az 5.17.f-g ábrán láthatóak, amelyekre egy-egy 800 nm sugarú korong illeszthető.

A párkereséshez a $\leq 50 \mathrm{~nm}$ laterális precizitású lokalizációk kerültek felhasználásra, amely szürési paraméter egyszerre volt érvényes az elsődleges- és másodlagos képre is. A végső szuperrezolúciós képek elkészítéséhez, a párosítás után a $\leq 25 \mathrm{~nm}$ precizitás szűrő került beállításra (amely megegyezik a szakromer mintáknál használt szüréssel). A kiszámolt mintára vett laterális feloldás a 2.10 képlet szerint: 25,91nm. Ezen érték a 2.3 táblázat alapján megegyezik egy tipikus 2D dSTORM felvétel mintára vett feloldásával.

Polarizáció/Anizotrópia modalitás • A másodlagos leképző karban egy polarizátor behelyezésével az emittált fény polarizáció szerint szürhető, ahogy azt az 5.15.b ábra (ii) elrendezésén is látható. A bevezetett polarizáció mértéke nem függ a polarizátor prizmától mért távolságától. Tengelye szerint viszont csak bizonyos szögekben volt behelyezhető, ugyanis a $\mathbf{P}$ képfordító prizma a polarizációt is a képfordításnak megfelelően forgatja. Ezért a prizma tengelyére merőleges és párhuzamos polarizációs irányok voltak csak használhatóak a kétszeri áthaladás miatt, mert ezeket a prizma nem befolyásolta. A mintából származó fény polarizáltságának meghatározásához meg kell határozni az elsődleges és a másodlagos kép intenzitását, valamint a másodlagos kép intenzitását a másodlagos kar transzmissziójával kell korrigálni (G-faktor). Tehát a 2.6.2 alfejezetben tárgyalt 2.11 képletben a nevező meg fog egyezni az elsődleges képen mért intenzitással, míg a másodlagos kép az elrendezésem szerint $I_{\|}$lesz. (A gerjesztő lézernyalábbal párhuzamosan állítottam be a polarizátort. ) A másodlagos karhoz tartozó G-faktor meghatározásához a gerjesztő nyalábútba, a minta konjugált síkjába (5.15a ábrán az Ap jelü penge helyett) egy $20 \mu m$ átmérőjű tűlyukat helyeztem. Mintának egy Oxazine 1 szerves festékből készített $10^{-4}$ 
oldatot használtam két fedőlemez között. Az így létrejövő fluoreszcens gyöngy méretü foltban a sugárzó festékek teljesen véletlenszerüen állnak, és a fényereje időben nem csökken a Brown-mozgás miatt, tehát használható referenciának ${ }^{3}$. Az így kapott érték nem az irodalomban használatos G-faktor lesz, mert nálam $G^{\prime}=I_{T} / I_{\|}$, ahol $I_{T}=I_{\|}+I_{\perp}$, vagyis az elsődleges képen mért intenzitás. Kiszámolva, a korrekciós faktora $G^{\prime}=5,2127$ érték adódott, és ahogy ebből már sejthető is, a modalitás legnagyobb problémája a másodlagos karban jelentkező fotonveszteség az optikai elemek transzmissziója, a polarizátor és a beállítási pontatlanságok miatt. A 2.11 képletet az alábbiak szerint módosítottam, hogy illeszkedjen a modalitáshoz:

$$
P^{\prime}=\frac{G^{\prime} \cdot I_{\|}}{I_{T}}
$$

Az értelmezhető $P^{\prime}$ értékek 0-2 között keresendőek, ahol 0-hoz a gerjesztésre merőleges-, 1-hez a teljesen depolarizált-, míg 2-höz a gerjesztéssel párhuzamos emisszió tartozik. A dSTORM felvételek készítésének módja és a méréshez használt mintája megegyezett a korábban bemutatott modalitásoknál tárgyaltakkal. Egy eredmény az 5.20 ábrán látható.



5.20. ábra. A polarizáció érzékeny modalitás muslica indirekt repülőizom mintán demonstrálva. A rekonstruált 2D képen jól kivehetőek a kettős vonalak (a), míg a polarizáltságot ábrázoló képen (b) sajnos az ábrázolt $P^{\prime}$ érték bizonytalansága látható.

A párkereséshez a $\leq 100 \mathrm{~nm}$ laterális precizitású lokalizációk kerültek felhasználásra, amely szürési paraméter egyszerre volt érvényes az elsődleges- és másodlagos képre is. A végső szuperrezolúciós képek elkészítéséhez, a párosítás után a $\leq 25 \mathrm{~nm}$ precizitás szürő

\footnotetext{
${ }^{3}$ Csillagászati távcsövek esetén használt „mesterséges csillag” trükkből inspirálódva https://www2. keck.hawaii.edu/optics/lgsao/.
} 
került beállításra (amely megegyezik a szakromer mintáknál használt szüréssel). A kiszámolt mintára vett laterális feloldás a 2.10 képlet szerint: 28,46nm. Ezen érték a 2.3 táblázat alapján közel egy tipikus 2D dSTORM felvétel mintára vett feloldásával egyezik meg. Bár a laterális feloldást sikerült megőrizni az elsődleges képen, a másodlagos képen a polarizátorral történő megvalósítás során fellépő fotonveszteség miatt a modalitás használata limitált. Ez különösen igaz az $P \rightarrow 0$ értékekhez közelítve. Az információ vesztést az küszöbölné ki, ha egymás után két felvétel készült volna ugyanarról a ROI-ról két különböző polarizátor állás mellett.

Többszínü modalitás • Egy emissziós szűrőt helyezve a másodlagos karba, különböző fluorofórok megkülönböztethetőek lesznek a mért intenzitás alapján aszerint, hogy a szűrő mennyire vág bele az egyes emissziós spektrumokba. Abban az esetben, ha az emissziós spektrumok átfednek, akkor az elsődleges és másodlagos karban mért intenzitást kell összevetni. Az így mért arányból meg lehet állapítani a fluorofór típusát. Két eltérő emissziós ablakban detektálható fluorofór esetén, amikor a spektrumok kevésbé fednek át, csak azoknak lesz másodlagos képe, amit a másodlagos karba helyezett szürő átenged. A párkeresés ad választ a festékek típusára.

A megvalósíthatóság ellenőrzéséhez a méréseket kétféle fluoreszcens gyöngyökből álló keveréken végeztem el (zöld lézerrel gerjeszthető: Applied Microspheres BV 30200 FR-CM-M, LOT: 171122; vörös lézerrel gerjeszthető: Life Technologies T7279, LOT: 1929718), amelyek a fedőlemezre voltak kötve poly-L-lysine-nel. A mintát alacsony teljesítménnyel $(<1 \mathrm{~mW})$ egyszerre gerjesztettem az $561 \mathrm{~nm}$ és az $647 \mathrm{~nm}$ lézerekkel, valamint a másodlagos leképző karba egy emissziós szürőt helyeztem (Semrock FF01-582/75-25), amely kiszürte a spektrum távoli vörös $(\geq 620 \mathrm{~nm})$ részét. A felvételt a teljes detektorméretet felhasználva készítettem $\left(512 \times 512 p x^{2}\right)$, a gerjesztő lézerek méreteinek $3 \times$ kitágítása (Thorlabs GBE03-A) mellett. Miután másodlagos képe csak a zöld lézerrel gerjeszthető fluoreszcens gyöngyöknek volt, így a párkeresési algoritmussal őket meg lehetett keresni és zölddel kódolni, a párral nem rendelkezőket vörössel. Az 5.21, ábrán a zölddel gerjeszthető fluoreszcens gyöngyök elsődleges képei kék négyzettel, míg a másodlagos képei sárga négyzettel vannak jelölve.

A nagy méretű felvétel kísérletileg is bizonyítja azt, hogy a kétobjektíves elrendezés a 




5.21. ábra. Kétszínü modalitás fluoreszcens gyöngyökön demonstrálva teljes detektor méreten. Azok a fluoreszcens gyöngyök, amelyek 561nm-es hullámhosszon is gerjeszthetöek, rendelkeznek másodlagos képpel. Amelyek csak $647 \mathrm{~nm}$-es hullámhosszon gerjeszthetöek, nem rendelkeznek másodlagos képpel. Intenzitás alapján eldönthetö párba rendezés után, a pár tagjai közül melyik elsődleges és melyik másodlagos. Forrása [A1].

teljes képtérre müködik és alacsony jelölési sűrüség mellett nem csökkenti a FOV értékét. A modalitással dSTORM mérések is készültek kettő színnel jelölt muslica indirekt repülőizom miofibrillumokon (kettinIg34-AF647 és Zasp52-AF568 jelölésekkel). Az ötlet az volt, hogy mindkettő jelölés a szarkomer I-sávjában legyen, ahol a kettin egy kettős vonal struktúrát, míg a zasp egy szimpla sávot jelöl (5.4.2 alfejezet). Azonban a felvételkészítés során több probléma is felmerült, ami miatt a felvett kép nem lett jó minőségü és nem lehetett a kettős vonalakat rekonstruálni. Különböző spektrumú festékek ideális kapcsolásához (például AF647 és AF568) az eltérő molekulaszerkezet miatt más switching buffer összetételre van szükség [102, 71]. A köztes switching buffert és a megfelelő festési sürüséget nem sikerült a projekt ideje alatt megtalálni, és ez azóta is egy nyitott kérdés. Emiatt a lokalizációk átfedtek és a kettin kettős vonala sem volt feloldható 5.22 . ábra). Ugyancsak leküzdendő probléma az AF568 anti-Stokes emissziója volt, ami a cikk írásakor még nem volt ismert számomra.

Bár a modalitás használhatóságát nem sikerült SMLM mérés keretében maradéktalanul bemutatni, egy jobban megválasztott festék kombináció esetén optikai részről nincs 


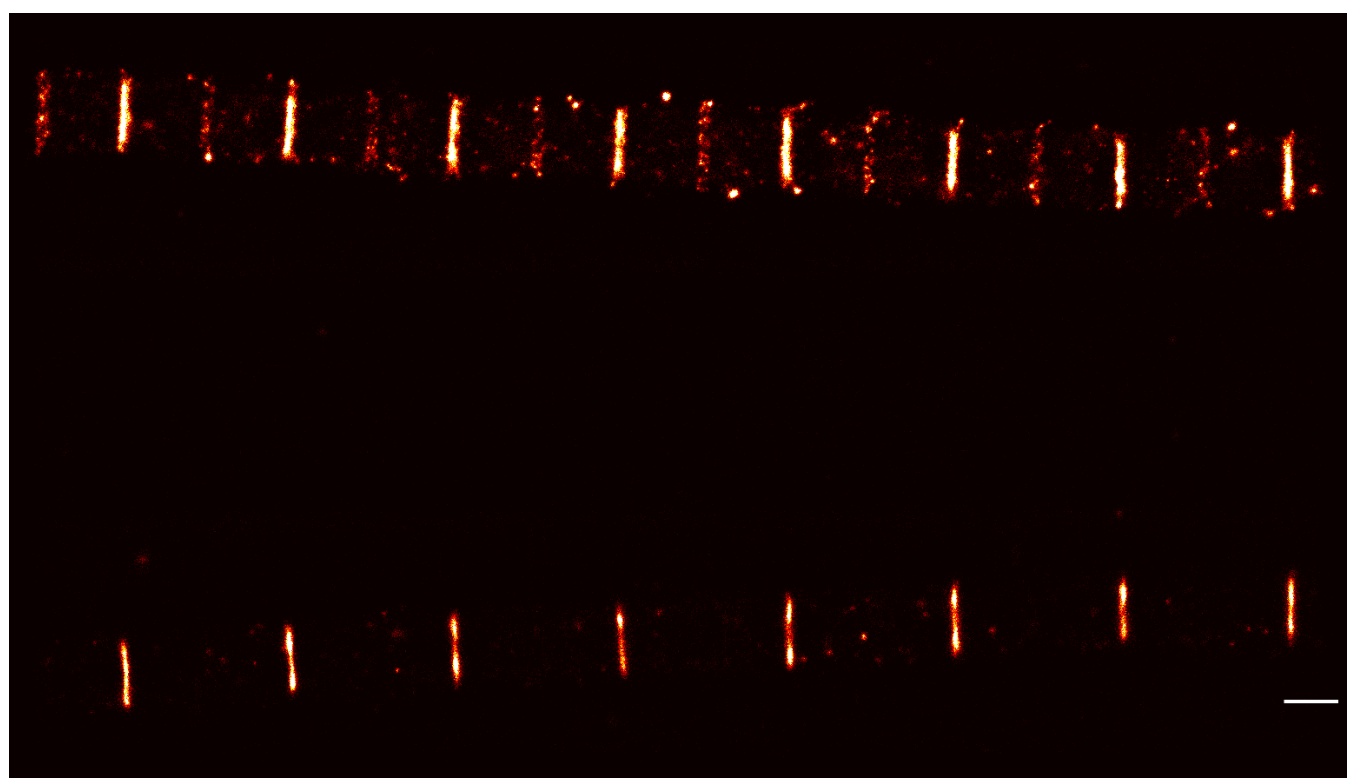

5.22. ábra. Kétszínü $\boldsymbol{d S T O R M}$ kép a kettinIg34-AF647 és Zasp-AF568 jelölt izomszálról. Szétválasztás után a felső kép az $\boldsymbol{A} \mathbf{F 6 4 7 - h e z ~ t a r t o z o ́ ~ l o k a l i z a ́ c i o ́ k a t ~ t a r t a l m a z z a , ~}$ míg az alsó az $\boldsymbol{A} \mathbf{F 5 6 8 - h o z ~ t a r t o z o ́ ~ l o k a l i z a ́ c i o ́ k a t . ~ A ~ s k a ́ l a ~} 1$ mikront jelöl.

akadálya a modalitás alkalmazásának. A disszertáció megírásáig az AF568 kapcsolhatóságának problémája továbbra is megoldatlan maradt. Helyette egy másik marketing családba tartozó festékkel, a CF568-cal kezdtünk el a többszínű dSTROM-ot tesztelni szekvenciális felvételkészítéssel.

\subsubsection{Az eredmények tézispontban megfogalmazva}

[T3]. Az egymolekula detektáláson alapuló lokalizációs mikroszkóphoz egy saját tervezésü két objektíves, Porro-prizmás elrendezést építettem meg a mintából származó fotonok hatékony összegyüjtéséhez és modalitásokkal történő méréshez. A két objektívből álló elrendezésre kidolgoztam a párkeresést és megvalósítottam két 3D-, egy dipól orientáció-, és egy többszínü modalitást. Az egyes modalitásokat alkalmazva dSTORM méréseket végeztem ecetmuslica indirekt repülőizom mintán és fluoreszcens gyöngyökön, tesztelve a rendszer használhatóságát és igazolva a lokalizációs precizitás megőrzését.

Kapcsolódó publikációk: A1, C1, P6-7, S2, S6 


\subsection{Muslica indirekt repülőizom fehérjeatlasza}

Az utolsó alfejezetben egy olyan alkalmazást mutatok be, ahol a dSTORM egy hátrányát kerültük meg egy jól választott biológiai probléma megoldásánál. Ha ugyanis több struktúrát szeretnénk egyazon mintán belül vizsgálni, akkor több fajta antitestet és festéket kell használni. De ahogy azt a 2.4.2, alfejezetben is említettem, az AF647 festékhez képest a többi festék rossz [72]. Mellé csak olyan, rosszabb tulajdonságokkal rendelkező eltérő spektrális tulajdonságokkal rendelkező párt lehet választani, ami müködik ugyanabban a switching bufferben. Hogyan lehet egy mintán belül kvantitatív módon, 25 nanométeres feloldással húsznál is több struktúrát megkülönböztetni? Mondhatni lehetetlen az eddig felvázolt technikákkal. Biológus együttmúködő partnerünkkel erre kerestük a választ egy kétéves mérési együttmúködés keretében, amit azóta is folytatunk. Mivel ez egy több fázisból és részelemből álló hosszabb projekt, ezért a fejezet elején pár mondatban bemutatom saját hozzájárulásom: az összes dSTORM mérést és azok feldolgozását én végeztem. A projekthez készült osztályozó szoftver [S3] fejlesztésében 50\%-os arányban vettem részt: PhD hallgatótársam készítette el a modellillesztő részt, és én feleltem az automatizálásért és az adatfeldolgozásért. A minta elkészítése és a molekuláris-biológiai modell kialakítása nem volt feladatom, ez az együttmüködő partnerhez tartozott. Az érthetőség miatt azonban minden részletről beszámolok, még ha nem is a teljesség igényével.

\subsubsection{Biológiai probléma}

A harántcsíkolt izmok legegyszerübb építőegységeit szarkomernek nevezzük. Az egyes miofibrillumokat ilyen ismétlődő, összehúzódásra képes funkcionális elemek alkotják 5.23 B ábra). A szarkomerek határai a Z-lemezek, befelé haladva megkülönböztetünk I-csíkot, A-csíkot, H-zónát és M-vonalat (5.23. C ábra). Fénymikroszkópos képen ezek a megkülönböztetett részek világos és sötét sávokat eredményeznek, amiről a nevét az izomtípus is kapta [121]. A muslica indirekt repülőizmára azért esett a választás, mert felépítésében hasonlít a gerincesek harántcsíkolt izmára, viszont annál sokkal egyszerúbb.

A szarkomerek belső ultra struktúrája vitathatatlanul bonyolult és nagyon rendezett, amit többféle elektronmikroszkópos (immun-arany jelöléssel) és röntgen krisztallográfiás módszerrel is vizsgáltak. Ezek a módszerek bár lehetővé tesznek nanométeres feloldást, a minta előkészítése során a struktúra roncsolódása elkerülhetetlen. A probléma megol- 

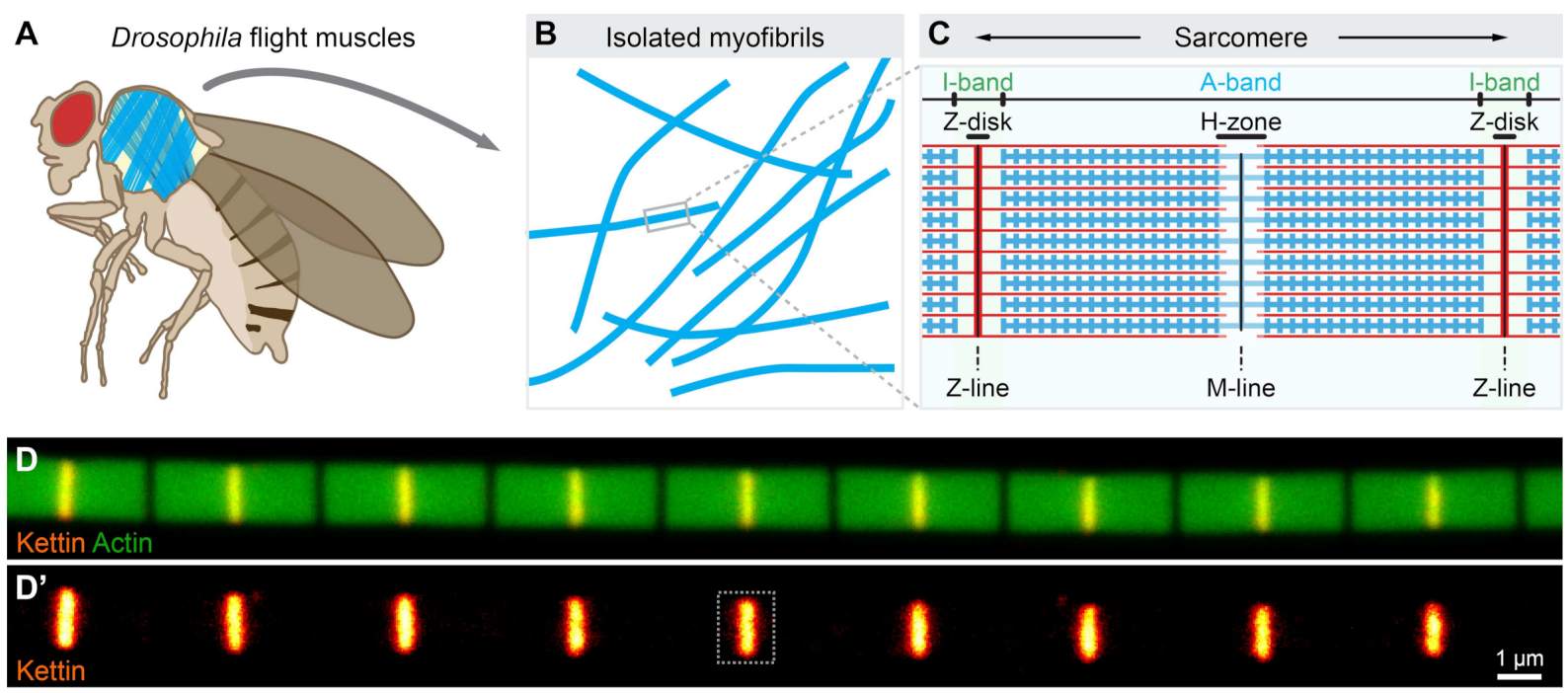

5.23. ábra. A muslica indirekt repülőizma (A), mint biológiai probléma. Az egyes miofibrillumok (B) épitőkövei a szarkomerek (C). Konfokális képen látható a kettin Z-lemez körüli felgyülemlése, míg a H-zónában az aktin hiánya(D, D’). Forrása [A2].

dásához ezért az optikai útra és a fluoreszcens mikroszkópiára esett a választás, hogy a vizsgálandó struktúra a mintában minél kevesebbet változzon annak előkészítése során. A partnerünk által kettin jelölt mintákon elvégzett előkísérletek (CLSM, SIM, STED, dSTORM) alapján megállapítható volt az, hogy az utóbbi technika nyújtja a legnagyobb elérhető feloldást és adja a legmegbízhatóbb eredményeket. Mivel a szarkomer hengerszimmetrikus (ahogy azt az 5.3 , alfejezet méréseiben is láthattuk), így ha a miofibrillum a fedőlemezre kitapad, akkor elegendő struktúrájának síkbeli vetületét vizsgálni és feltérképezni. Az egyes szarkomer-alkotó fehérjék epitópjait jelölve immunhisztokémiai módszerekkel megkapható azok eloszlása az izomszál mentén. A trükk, amivel a többszínü dSTORM kikerülhető, megsejthető az 5.23.D ábrája alapján. Mivel az egyes miofibrillumok ismétlődő struktúrákból épülnek fel, ezért egy mintakészítés során elegendő azok közül csak egy epitópot jelölni a dSTORM méréshez. A miofibrillumon belüli tájékozódáshoz, például az M-vonal megtalálásához használható egy másik jelölés-másik festékkel, amiről elegendő csak „hagyományos”, epifluoreszcens módon felvételt készíteni. Az egyes fehérjékre kapott eredmények összeadhatóak függetlenül attól, hogy melyik izomszálon vagy melyik festés során készült a felvétel. Sőt nem kell csak kép szintjén gondolkodnunk. Az SMLM mikroszkópos adatfeldolgozás eredményeit akár lokalizált koordináták 
szintjén is összeadhatjuk, és így tetszőleges számú struktúráról (epitóp eloszlásról) készült felvételeket tudunk egymásnak megfeleltetni vagy megkülönböztetni. A biológiai probléma megoldása így leválasztható a dSTORM festékválasztás problémájáról.

\subsubsection{Miofibrillumok dSTORM mérése, feldolgozása és kvantifikálása}

Egy adott fehérjéhez vagy epitóphoz „,jó statisztikát” tudjunk elérni, ahhoz három független mintakészítés történt. A miofibrillumok közel 20 egyedből lettek izolálva egy mintakészítéshez. (Ennek lépései, és a szálkötegek szétbontásának folyamata a kapcsolódó A2 publikációban olvashatóak.) Olyan preparátumok mérését is elvégeztem, ahol a repülöizom egyben volt hagyva, megbizonyosodva arról, hogy a miofibrillumok preparálása nem vezet be hibát.

Az egyes mintákon belül a miofibrillumokról több dSTORM felvétel készült a 4.5 alfejezetben tárgyaltak szerint. A hosszú felvételek (20k-50k képkocka) miatt lehetöség volt a lokalizációk elfogadásánál szigorúbb feltételeket választani, így a lokalizációs pontosság felső határát $<5 \mathrm{~nm}$-re, az illesztett Gauss-függvény elfogadható félérték szélességét a $0,7 \leq W \leq 1,5$ tartományra szúkítettük. Ezekre az átfedő kapcsolási események és a fókuszsíkon kívüli pontatlanabb események kiszürése miatt volt szükség. A szuperrezolúciós képeket 10nm-es szuperpixel mérettel rekonstruáltam. A teljes mérési kampány végére $\approx 1000$ felvétel keletkezett $\approx 2 T B$ összmérettel. Bár a mikroszkóp és a mikroszkóp operátor személye nem volt skálázható, a kezdeti mérések során meghatározott illesztési és elfogadási paraméterekkel legalább a nyers felvételek feldolgozását lehetett automatizálni. Ezért módosítottam saját lokalizációs szoftverünket, a RAINSTORM-ot[[S3], hogy kötegelt feldolgozásban (batch processing) emberi beavatkozás nélkül képes legyen futni és a megfelelő laterális drift korrekciót [110] is elvégezni.

Az így kiértékelt szuperrezolúciós képeken az együttmúködő partner epitóponként tipikusan 200-500 szarkomer egységet jelölt ki elemzésre. Ehhez egy, a RAINSTORM-hoz fejlesztett exportáló eszközt használt, ami a kijelölt terület lokalizációs adatsorát (koordináták és illesztési paraméterek) egy fájlba tárolta le későbbi felhasználásra. A miofibrillumon belül a H-zónáknál és a Z-lemezeknél a lokalizációk eloszlása három osztályra lett bontva: „dupla vonal”, „szimpla vonal”, „rés” (5.24a ábra). Ezen eloszlások további elemzéséhez egy grafikus kezelőfelülettel is rendelkező osztályozó programot fejlesztettünk 
(IFM ANALYZER [S4]) Mathworks Matlab 2018b környezetben. Előnye az volt, hogy lehetőség volt egyenként, felügyelve elvégezni az osztályozást és az elemzést. De egy mappa teljes tartalmát is fel tudta dolgozni felügyelet nélkül, amit elegendő volt utólagos minőségellenőrzésnek alávetni.

Az első lépésben a program a lokalizációkra egy egyenest és egy $600 \times 800 \mathrm{~nm}^{2}$ méretü téglalapot illeszt 5.24.b ábra). A további kvantitatív feldolgozáshoz csak a megjelölt területen belül elhelyezkedő lokalizációk vannak figyelembe véve. A téglalap méretét tipikusan háromszor-négyszer szélesebbre és 10\%-kal rövidebbre kell választani a struktúránál, hogy az illesztést el tudja végezni biztosan a program mögött lévő algoritmus. A második lépésben a kijelölt területen belül a struktúra szimmetria tengelye, pontosabban fogalmazva a szimmetria görbéje kerül meghatározásra, amelynek leírására egy másodfokú polinomot használ a program. Gauss-elmosással kisimítva a lokalizációk eloszlását az illesztés egyértelmü minimumot talál dupla vonal vagy rés esetén. Szimpla vonal esetén a keresett megoldás a maximumhely 5.24 c ábra). Az egyes lokalizációk görbétől vett távolságát hisztogramon ábrázolva megkapható a festékek eloszlása 5.24.d ábra), amiből még ki kell következtetni az elsődleges antitest kötőhelyeit. A lokalizációk eloszlásának és az epitópok eloszlásának különbözőségét a lokalizációs precizitás és az elsődleges-másodlagos antitest mérete vezeti be. A lokalizációs precizitást egy Gauss-függvénnyel lehet figyelembe venni. A polarizáció érzékeny mérések eredményei alapján, amik nem mutattak irányorientációt feltételezhető az, hogy az antitest a kötőhely körül egy állandó sugarú gömb felületén engedi meg a festék mozgását. Az expozíciós idő alatt pedig a teljes gömbfelszínt véletlenszerüen bejárja az. Az utolsó lépésben ezek az epitóp eloszlások kerülnek meghatározásra, amiből a struktúrára vonatkozó adatok is kinyerésre kerülnek: dupla vonal esetén a csúcsok távolságának fele, szimpla vonal esetén az egyetlen csúcs félértékszélességének fele, valamint rés esetén annak félszélessége 5.24 .e ábra). Ezeket a program fehérjénként egy-egy táblázatba tárolta, amelynek elemzését egyéb szoftverekben folytatni lehetett (Mathworks Matlab, RStudio).

Az általunk választott módszer előnye, hogy lokalizált koordinátákkal dolgozik, nem egy képen. Minden egyes pixelhez tehát megvan az azt alkotó kapcsolási események tulajdonságai. Az átméretezés és a transzformáció során nem kell újramintavételezni a pixelizált képet, csak a koordinátákon elvégezni a müveleteket és rekonstruálni a képet. A 


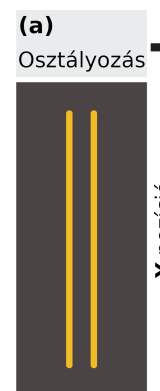

Dupla vonal

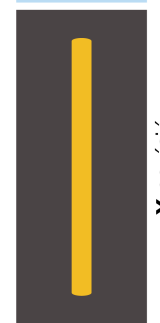

Sáv

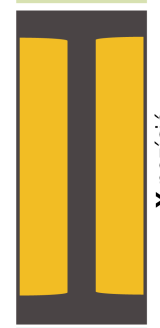

Rés

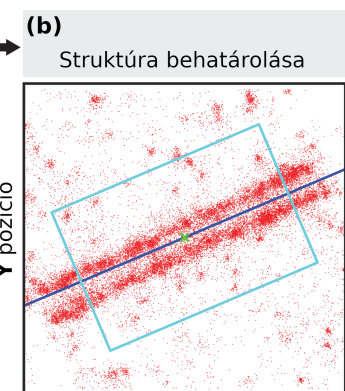

X pozíció

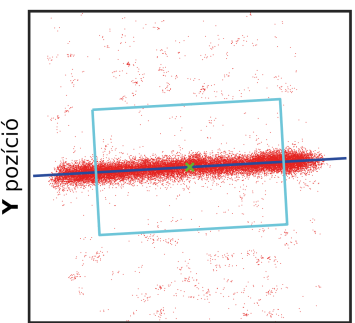

X pozíció

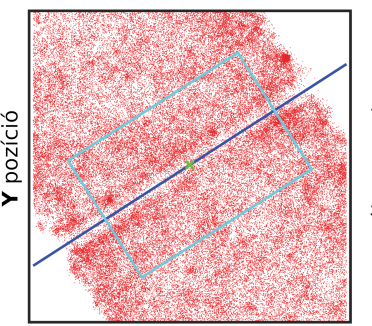

X pozíció

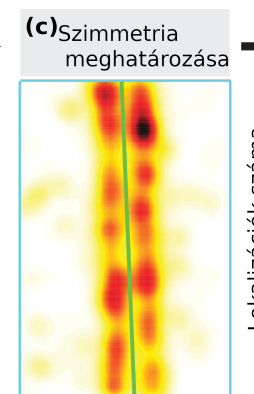

új $\mathbf{X}$ tengely

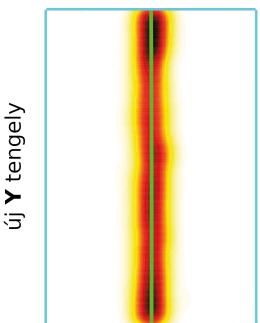

új $\mathbf{X}$ tengely

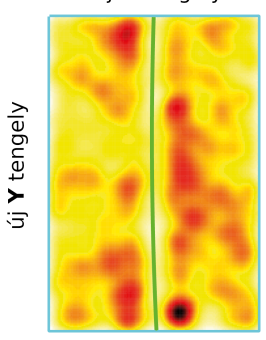

új $\mathbf{X}$ tengely

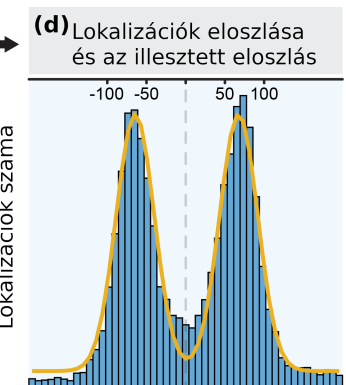


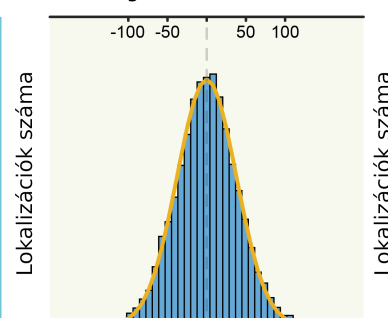

távolság az M/Z-vonaltól (nm)

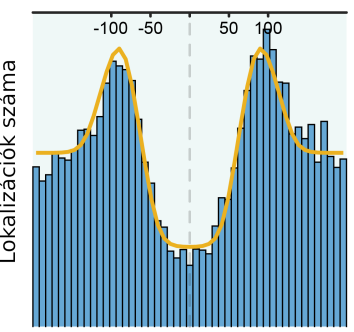

távolság az M/Z-vonaltól (nm)
)

(e)Lokalizációk és epitópok illesztett eloszlása

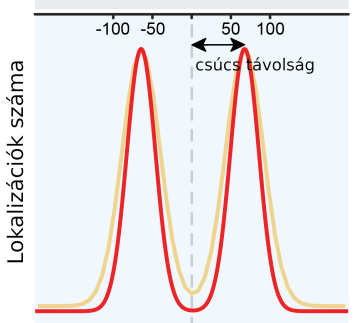

távolság az M/Z-vonaltól (nm) \begin{tabular}{ll|ll}
-100 & -50 & 50 & 100
\end{tabular}



távolság az M/Z-vonaltól (nm)

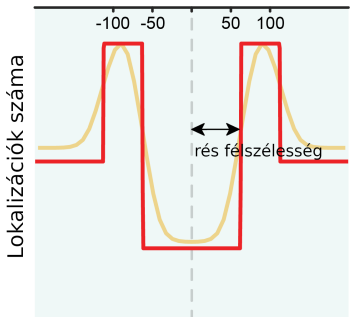

távolság az M/Z-vonaltól (nm)

5.24. ábra. Szarkomer struktúrák elemzésének lépései a lokalizációs adathalmaz alapján. Az adatfeldolgozás három osztályozási sablon szerint történt (a). A kiválasztott területen egy elsődleges becsléssel a struktúra kiterjedése és szimmetria tengelye kerül meghatározásra (b). Ezt követi a struktúra szimmetria tengelyének egy másodfokú polinommal történö közelitése a lokalizációk sürüségének alapján (c). Az egyes lokalizációk görbétől mért távolságát egy hisztogramon ábrázolva megkapható azok eloszlása (d). Végezetül egy elméleti görbével (vörös vonal) az epitóp eloszlás kerül meghatározásra (e). Forrása [A2]. 
rekonstrukciókat különböző színnel jelölve elkészíthető a keresett H-zónát vagy I-sávot határoló struktúrák szuper-rezolúciós képe 5.25 ábra).
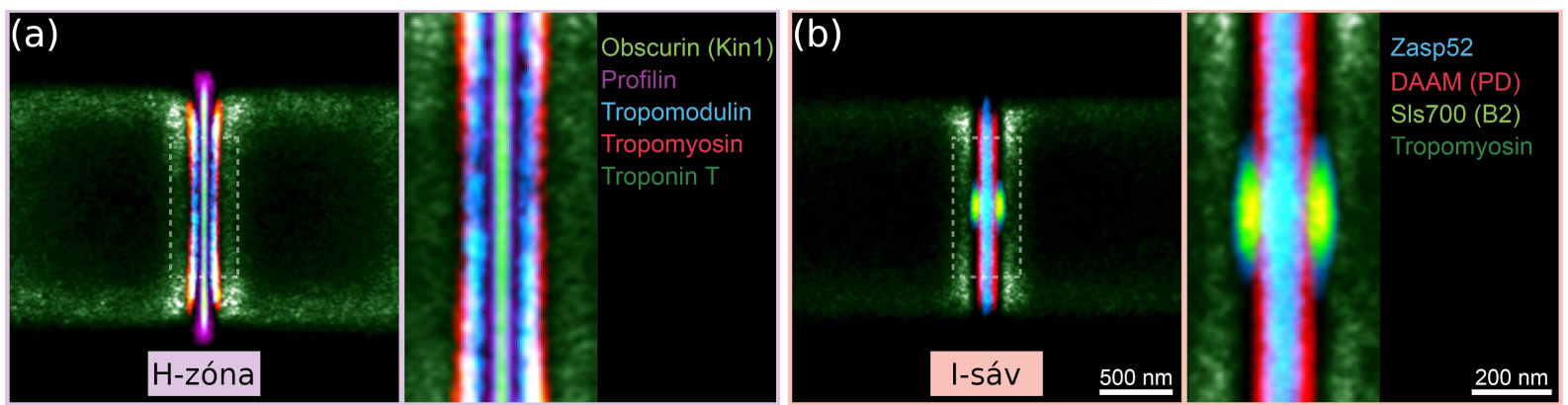

5.25. ábra. A szarkomert alkotó fehérjék a H-zónára (a) és az I-sávra (b) vett összegképe, álszínekkel megkülönböztetve. Az egyes struktúrák lokalizációs adatai az IFM ANALYSER [S4] programmal lettek centrálva és összeadva rekonstrukció elött. Ábrarészlet az [A2]böl.

A muslica indirekt repülőizmának extrém rendezett struktúrája lehetővé tette azt, hogy kidolgozzunk egy olyan lokalizációs mikroszkópiás eljárást, amivel több fehérje és azok különböző epitópjai vizsgálhatóak voltak. Tettük mindezt úgy, hogy a lokalizációs pontosságot minden struktúra esetén $\sim 5-10 n m$-es értékre leszoríthattuk, köszönhetően annak, hogy több mint 9000 szarkomer egységet értékeltünk ki. A kapott adatokból egy atlasz összeállítására volt lehetőség, amelynek lokalizációs mikroszkópiás része az 5.26 ábrán látható H-zónára és I-sávra szétbontva. A kapcsolódó részletes, struktúra modelleket is tartalmazó ábra az [A2] hivatkozás mellékletében található.

\subsubsection{Az eredmények tézispontban megfogalmazva}

[T4]. Ecetmuslica indirekt repülőizom fehérjestruktúrájának meghatározásához készítettem dSTORM méréseket. A feldolgozás felgyorsításához a lokalizációt és a rekonstrukciót automatizáltam. A miofibrillumon belül három eloszlás osztályt („kettős vonal”, „szimpla vonal”, „rés”) különböztettünk meg a 35 vizsgált struktúra csoportosítására. Ezek kiértékeléséhez egy új osztályozó szoftvert fejlesztettünk, amely az egyes osztályokra jellemző paramétereket határozta meg.

Kapcsolódó publikációk: A2, S3-4 

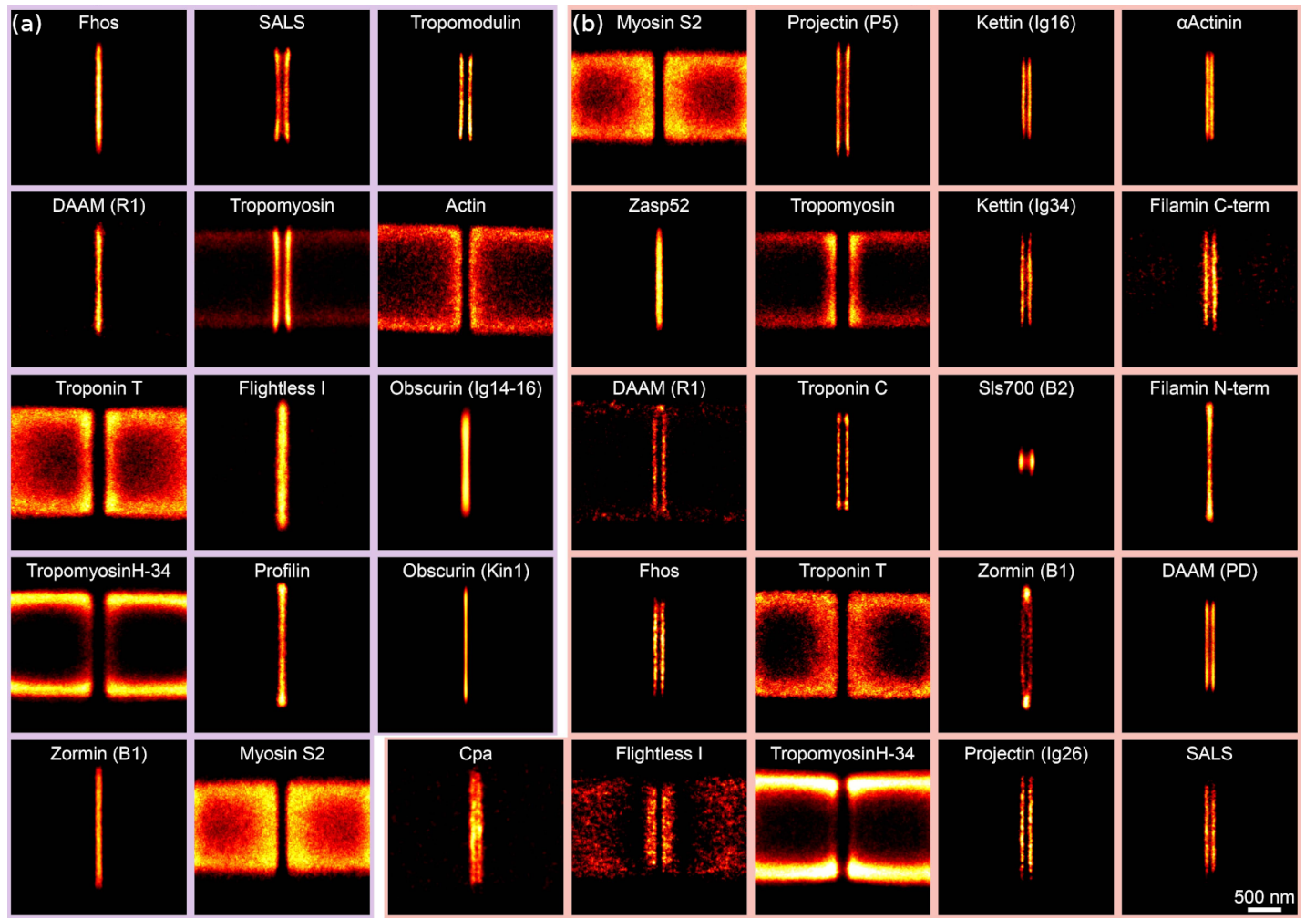

5.26. ábra. Az együttmüködés keretében vizsgált 27 szarkomert alkotó fehérje összesen 35 epitóp helyének a H-zónára (a) és az I-sávra (b) vett összegképei rekonstruálva. Az egyes struktúrák lokalizációs adatai az IFM ANALYSER [S4] programmal lettek centrálva és összeadva rekonstrukció elött. Forrása [A2]. 


\section{6. Összefoglalás}

\subsection{Bevezetés}

A fluoreszcencia már több évszázada tárgya és eszköze a tudományos kutatásoknak. A gerjesztő és az emittált foton energiakülönbsége miatt létrejövő Stokes-eltolást, mint egy kontraszt növelő technikát, ki lehet használni a mikroszkópokban. Ez az energiakülönbség azonban létrejöhet ellentétes relációval is, és ekkor a folyamatot anti-Stokes fluoreszceniának nevezzük. A hiányzó energia a folyamat lejátszódásához egy második fotonból vagy hőenergiából származhat. Az utóbbi esetet nevezzük forró-energiasávos abszorpciónak.

Egy optikai mikroszkópban a képalkotás pásztázási-, illetve széleslátóterü módban történhet konstrukció szerint. Problémát jelent azonban a fény hullámtermészete, ami korlátozza két fluorofór megkülönböztethetőségét, a feloldás ugyanis véges. A Rayleigh-féle feloldási kritérium megadja ezt a közel 300nm távolságot laterálisan, és ennek áttörtésére sok trükkre és megvalósított technikára volt szükség.

Az optikai trükköket és a festékek fotofizikai-fotokémiai tulajdonságait is kihasználó feloldásnövelő technikákat szuperrezolúciós technikáknak nevezzük. Pásztázó képalkotási módban a stimulált emissziót kihasználó technika, a STED volt az első, míg nagylátótér esetén 2006-ban több hasonló elven müködő technika jelent meg. Ezen utóbbiakat közös gyüjtőnévvel egymolekula detektáláson alapuló lokalizációs mikroszkópiának, vagy SMLM-nek hívjuk. Fluoreszcensen inaktív, de kapcsolható fehérjékkel müködik a PALM technika, a GSDIM szerves festékek fotofizikáját használja ki, a dSTORM pedig ugyancsak szerves festékek fotokémiáját. Mindhárom esetben a végeredmény ugyanaz: térben és időben elkülönült kapcsolási események, amelyekre már nem vonatkozik a Rayleighkritérium. Az így megkülönböztetett fluorofórokra illesztve a pontátviteli függvényt, megkapható annak maximumhelye a pixelen belül. Ez a mikroszkópos technika azonban fotonlimitált, a helymeghatározás precizitása nagyban függ a jel-zaj viszonytól. Az egyes illesztések jósága a Thompson-képletből [83] számolható, míg a mintára vonatkoztatott feloldás kiszámolható a lokalizációs precizitások várható értékeiből [88]. A végső kép szoftveresen, pointillista módon, a rekonstrukció során állítható elő a legnagyobb lokalizációs precizitással rendelkező maximum helyekből. A kapcsolási mechanizmus szimulálására, a felvételek elemzésére és a rekonstrukció elvégzésére csapatunk két szoftvercsomagot, a 
TESTSTORM-ot B4 és a RAINSTORM-otS4 fejlesztette ki.

Lehetőség van az SMLM technikát kibővíteni, és ez által többlet információt kinyerni a fluorofórok x és y pozícióján felül. A harmadik koordináta kinyeréséhez a legelterjedtebb modalitás a 3D asztigmatizmus. Egy, a detektor karba helyezett hengerlencse segítségével a rendszer pontátviteli függvénye úgy módosul, hogy a fókuszsík alatt és felett a molekula képe elliptikus és a fókuszsíkra nézve aszimmetrikus is lesz. A z koordináta meghatározása visszavezethető az ellipszis két tengelyének arányosítására. Egy másik módszer a 3D kétsíkú leképezés. A detektor kart optikai módon ketté bontva egy nyalábosztó kockával úthossz különbség vezethető be az így létrejövő karok között. Ez két eltérő fókuszsíkot is eredményez. A harmadik koordináta meghatározása ebben az esetben a két kép méretének mérésére vezethető vissza. Hasonlóan kettébontható a keletkező kép egy polarizációs nyalábosztó kockával, egy Wollaston-prizmával, vagy egy kettősen törő ékkel B3]. Ez által meghatározhatóvá tehető a fluorofór dipólusának a gerjesztő lézer polarizációjára vett szöge és annak bizonytalansága például anizotrópia számoláshoz. Ebben az esetben a fluorofórról keletkező két kép intenzitásának arányát kell meghatározni. Festékmolekulák spektrálisan történő szétválasztása történhet egy jól megválasztott emissziós szürővel. Követve az előző gondolatmenetet, az eltérő Stokes-eltolással rendelkező, de ugyanazzal a lézerrel gerjeszthető festékek a két csatornában mért intenzitásaik összehasonlításával megkülönböztethetőek. Egy diszperziós elemmel (prizmával vagy ráccsal) a kép spektrálisan felbontható, lehetővé téve a spektrum direkt meghatározását. A probléma ezekkel a PSF módosításokkal, hogy a többlet információ kinyerése, az esetek többségében, az egy pixelre eső fotonszám csökkenésén vagy a PSF torzulásán keresztül rontja az elérhető lokalizációs precizitást és ez által az elérhető feloldást.

\subsection{Célok és kutatási módszerek}

Kutatási célom ezért az, hogy olyan új mérési elrendezések tervezése és mérési modalitások megvalósítása az SMLM technikához, amelyek megőrzik a laterális precizitást és feloldást. Valamint az, hogy ezek a mérési módok egyszerűen legyenek alkalmazhatóak egy meglévő optikai mikroszkóp rendszeren. Az elért új tudományos eredményeket három nemzetközi referált folyóiratban jelentettem meg, amelyeket négy tézispontban foglalok Össze. 
A kísérleteim kivitelezéséhez az AdOptIm kutatócsoport dSTORM-CLSM-FLIM mikroszkópját használtam, amely megépítésében és többszöri átépítésében is részt vettem. Méréseimet mindhárom technikával készítettem.

\section{3. Új tudományos eredmények}

T1 Az Alexa Fluor 568 forró energiasávos abszorpciójának bizonyításához hullámhossz függést, spektrális tulajdonságot, hőmérséklet függést és fluoreszcencia élettartamot mértem. Méréseimet összehasonlító jelleggel a már ismert Rhodamine 101 és az egymolekula detektáláson alapuló mikroszkópiában használatos Alexa Fluor 568 szerves festékre végeztem el. Megmutattam azt a tudományos irodalomban nem ismert tényt, hogy az Alexa Fluor 568 is forró energiasáv elnyelő. Végezetül javaslatot tettem a forró energiasávos antiStokes fluoreszcencia alkalmazására dSTORM és EPI mérések során (autofluoreszcenciacsökkentett képalkotás, struktúra jelölő, laterális drift becslés és lokális hőmérséklet mérés) A3, S5.

T2 Egy új, leképzésen alapuló, kétobjektíves, Porro-prizmás mikroszkópos elrendezést terveztem és modelleztem nyalábkövető optikai szimulációs szoftverrel. A javasolt optikai elrendezés összegyüjti a korábban képalkotásra fel nem használt fotonokat, és azt a mikroszkóp számára valós tárgyként felhasználhatóvá teszi. OSLO optikai szimulációs programban elkészítettem a két leképző kar modelljét a két kép létrejöttének szimulálásához, továbbá összevetettem a kapott pontátviteli függvényeket a fókuszsíkban és axiális vetületekben. Szimulációkkal igazoltam azt, hogy a javasolt elrendezés alkalmas egymolekula detektáláson alapuló mérésekhez A1 P3-5.

T3 - Az egymolekula detektáláson alapuló lokalizációs mikroszkóphoz egy saját tervezésü két objektíves, Porro-prizmás elrendezést építettem meg a mintából származó fotonok hatékony összegyüjtéséhez és modalitásokkal történő méréshez. A két objektívből álló elrendezésre kidolgoztam a párkeresést és megvalósítottam két 3D-, egy dipól orientáció-, és egy többszínű modalitást. Az egyes modalitásokat alkalmazva dSTORM méréseket végeztem ecetmuslica indirekt repülőizom mintán és fluoreszcens gyöngyökön, tesztelve a rendszer használhatóságát és igazolva a lokalizációs precizitás megőrzését A1, C1, P6-7. 
S2. S6.

T4 Ecetmuslica indirekt repülőizom fehérjestruktúrájának meghatározásához készítettem dSTORM méréseket. A feldolgozás felgyorsításához a lokalizációt és a rekonstrukciót automatizáltam. A miofibrillumon belül három eloszlás osztályt („kettős vonal”, „szimpla vonal”, „rés”) különböztettünk meg a 35 vizsgált struktúra csoportosítására. Ezek kiértékeléséhez egy új osztályozó szoftvert fejlesztettünk, amely az egyes osztályokra jellemző paramétereket határozta meg A2, S3-4. 


\section{Summary}

\subsection{Introduction}

Florescence has been the subject and also a tool in scientific research for multiple centuries. The energy difference between the absorbed and emitted photon's energy (which is called Stokes-shift) can be used in the microscope as a contrast-enhancing technique. But this energy difference can also emerge in a negative relation. This process is called anti-Stokes fluorescence, and before completion the missing energy has to be provided to the fluorophore. This can be a second photon or thermal energy. In the latter case we call the process hot-band absorption.

In a microscope the image can be formed using point-scanning or widefield imaging. Using imaging techniques a problem arises, which is related to the wave nature of light, which renders the achievable resolution finite and restricts the discrimination of two neighbouring fluorophores. This minimal lateral distance is $\approx 300 \mathrm{~nm}$, which is given by the Rayleigh criterion. To break this limit many tricks and realized technique had to be applied.

Resolution enhancing techniques which take advantage of optical tricks and the photophysical and photochemical properties of fluorescent dyes can be labelled as superresolution. The first technique which satisfied these criterion was STED which uses the stimulated emission and a point-scanning imaging mode. In widefield multiple similar techniques were implemented in 2006 and later a common collective name was given: singe-molecule localization microscopy, or SMLM for short. The PALM technique is based on the use of fluorescently inactive, but switchable proteins. A similar technique, the GSDIM takes advantage of the photophysics (triplet states) of some organic fluorescent dyes, while dSTORM takes advantage of the photochemistry (long dark states). The end result is the same for all three: spatially and temporally separated switching events to which the Rayleigh-criterion does not apply. By fitting the differentiated fluorophores with the point spread function, the location of the maximum value is obtainable within a pixel. This microscope technique is photon limited, thus the location determination's precision depends on the signal-to-noise ratio. The goodness of a fit can be calculated from the Thompson-formula [83], while the resolution is obtainable as a blind estimate from the 
the expected value of the standard deviation [88]. The final image can be reconstructed using software based solutions in a pointillist style, using only the coordinates with the highest localisation precision. We developed two software packages, TESTSTORM B4 and RAINSTORM[S4, to simulate the switching mechanism, to analyse the recorded frame stack, and to reconstruct the super-resolved image.

The SMLM techniques can be expanded to obtain an excess information above the fluorophores $\mathbf{x y}$ coordinates. 3D astigmatism is the most widely used modality to extract the third spatial coordinate. The point spread function modification is introduced via cylindrical lens in the detector pathway. It is modified to be elliptical above and below the focal plane and also asymmetric to the focal plane. The $\mathbf{z}$ coordinate can be deducted using the ratio of the two axes of the fitted point spread function. A second method is the 3D bi-plane modality. Here the detector path is separated into two, with a slight length difference between the paths. This creates two separate focal planes. The third coordinate can be deduced by measuring the size of the two images. In a similar manner the image can be splitted using a polarization beamsplitter cube, a Wollaston-prism or a birefringentwedge B3]. By determining the intensity ratio of the two images the fluorophores dipole orientation can be determined or it's uncertainty to calculate the anisotropy for each single source. The spectral separation of fluorescent dyes is achievable with the use of specially selected dichroic mirror and emission filters. Following the previous theme, the fluorescent dyes excited with the same laser source but with a different Stokes-shift can be separated by measuring the intensity in the two spectral channels. Using a dispersion element (prism or grating) the image can be spectrally resolved. This way the emission spectrum can be directly determined. The problem with these PSF modifications are, that each can degrade the achievable resolution by lowering the number of photons-per-pixel or by introducing PSF distortions.

\subsection{Objectives and methods}

To overcome this issue, my research goal was to design new experiment arrangements and to implement new measurement modalities in SMLM techniques, which preserve the lateral localization precision and resolution. These measurement modes should be easily applicable on an existing microscope system. The achieved new scientific results were 
published in three international, referred journals, and I summarize them in four thesis points.

To conduct the experiments, I used the AdOptIm researchgroup's dSTORM-CLSMFLIM microscope. I also participated in the construction and in multiple reconstruction of the said microscope. The required measurement were carried out using these three techniques.

\subsection{New scientific results}

T1 To demonstrate the hot-band absorption properties of Alexa Fluor 568; wavelength dependence, spectral properties, temperature dependence, and fluorescent lifetime was measured. The measurements were preformed in a comparative style on the well-known Rhodamine 101 and on Alexa Fluor 568, which is a widely used organic dye in singlemolecule localization microscopy. Based on these results I concluded that the Alexa Fluor 568 is a hot-band absorbing dye, which was previously not known in the scientific literature. Finally I proposed possible applications regarding the use of the anti-Stokes fluorescence in dSTORM and EPI measurements (autofluorescence-free imaging, structure marker, lateral drift estimation and local temperature sensing). A3, S5,

T2 A new dual-objective optical imaging system with a Porro-prism was designed and modelled using optical ray-tracing software. The proposed optical design collects the photons which were not used in image formation, and makes them usable in the form of a real object for the microscope. In OSLO optical simulation software I prepared the two imaging arm model to simulate the formation of the two images, furthermore the obtained point spread functions were compared in the focal plane and in axial projection. I showed, that the proposed layout is suitable for to be used in single molecule detection based measurement techniques. A1 P3-5

T3 I upgraded a single-molecule localization microscope with my self-designed dualobjective imaging system with Porro-prism to enhance the photon collection from the sample and to facilitate the application of modalities during measurements. I worked out the pair-finding for the dual-objective arrangement and built two 3D-, one dipole 
orientation- and one multicolour modality. With the application of each modality I made dSTORM measurements on fruitfly indirect flight muscle myofibrill samples and fluorescent beads to test the arrangement's usability and to prove the preservation of the localization precision. A1, C1, P6-7, S2, S6

T4 I performed dSTORM measurements to characterize fruitfly indirect flight muscle protein structure. To speed up the data processing I automatized the localization and the reconstruction process. In the myofibrill three distribution type were classified ("double line", "single line", "gap") to group the 35 examined protein structure. To evaluate these a new classifier software was developed, which extracts the characteristic parameters from the raw data. A2, S3-4 


\section{Köszönetnyilvánítás}

A doktori disszertáció jellegéből és követelményeiből adódóan a pozitív és cikk formájában publikált eredmények bemutatásáról szól. Azonban nem minden intuíció ${ }^{\mathrm{TM}}$, ötlet, elvégzett feladat és projekt jut el ebbe a kitüntetett státuszba. Útbaigazítások nélkül, amiből sokat kértem is és kaptam is pedig még ilyen vastag sem lenne a disszertációm.

Szeretném megköszönni témavezetőmnek, Dr. Erdélyi Miklósnak, mindennemü támogatását, segítségét, és végtelen türelmét, hogy MSc végétől kezdve folyamatosan támogatta tudományos tevékenységemet, csetléseimet és botlásaimat. Köszönettel tartozom az $A d$ vanced Optical Imaging Group jelenlegi és volt tagjainak - különösen Ponyeczkiné Cvik Elvirának és Dr. Sinkó Józsefnek - szakmai tanácsaikért, a támogató beszélgetésekért és a mindennapos, kutatómunkában nyújtott segítségükért. Örülök annak, hogy sikerült hozzájárulnunk egy jó hangulatú munkaköri légkör megteremtéséhez.

Köszönöm az együttműködő partnereknek, hogy segítettek eligazodni tudományterületük rejtélyes útvesztőiben, és ha „biológiai mintára” volt szükségünk, akkor szinte azonnal segítettek.

Családom tagjainak hálás vagyok a sok támogatásért és mindennapos biztatásért, mellyel a kudarcélményeimet ellensúlyozták.

Köszönöm Elbakyan Alexandra indirekt segítségét amivel lehetővé tette olyan falak átugrását, amely mögött értékes tudás volt meglelhető.

Doktori tanulmányaim során munkám és a kutatást a következő pályázati források támogatták: Nemzeti Agykutatási Program (KTIA-13-NAP-AI/14, 2017-1.2.1-NKP-201700002); GINOP-2.3.2-15-2016-00036; EFOP-3.6.1-16-2016-00008; Nemzeti Tehetség Program (NTP-NFTÖ-17-B-0310); University of Szeged Open Access Fund. 


\section{Publikációs lista}

MTMT azonosító: 10055222

\section{Tézispontokhoz kapcsolódó cikkek}

[A1] T. Gajdos, Zs. Cserteg, Sz. Szikora, T. Novák, B. B. H. Kovács, G. Szabó, J. Mihály, M. Erdélyi (2019). mmSTORM: Multimodal localization based super-resolution microscopy. Scientific reports, 9(1), 798. Q1 IF : 4,011 (2018); doi:10.1038/s41598-018-37341-9

[A2] Sz. Szikora, T. Gajdos, T. Novák, D. Farkas, I. Földi, P. Lenart, M. Erdélyi, J. Mihály (2020). Nanoscopy reveals the layered organization of the sarcomeric $H$ zone and I-band complexes. Journal of Cell Biology, 219(1). Q1 IF : 8,891 (2018); doi:10.1083/jcb.201907026

[A3] T. Gajdos, B. Hopp, M. Erdélyi (2020) Hot-band anti-Stokes fluorescence properties of Alexa Fluor 568. Journal of Fluorescence, x(x), xxx. Q3 IF : 1,913 (2018); doi:10.1007/s10895-020-02496-0

\section{Tézispontokhoz nem kapcsolódó cikkek}

[B1] Zs. Farkas, T. Gajdos, B. Major, A. Nagy (2011). Korok és tudósok-a színpadon Arkhimédész, Galilei és Newton: a szegedi Kutatók Éjszakájától a koppenhágai Science on Stage-ig. FIZIKAI SZEMLE, 2011(7-8), 267-272.; http://fizikaiszemle.hu/archivum/fsz110708/Farkas-Zsuzsanna.pdf

[B2] M. Erdélyi, J. Sinkó, T. Gajdos, T. Novák (2017, February). Enhanced simulator software for image validation and interpretation for multimodal localization superresolution fluorescence microscopy. In Single Molecule Spectroscopy and Superresolution Imaging X (Vol. 10071, p. 100710X). International Society for Optics and Photonics.; doi:10.1117/12.2250116

[B3] Sinkó, J., T. Gajdos, E. Czvik, G. Szabó, M. Erdélyi (2017). Polarization sensitive localization based super-resolution microscopy with a birefringent wedge. Methods and applications in fluorescence, 5(1), 017001. Q1 IF: 2,209 (2017);

doi:10.1088/2050-6120/aa6260

[B4] T. Novák, T. Gajdos, J. Sinkó, G. Szabó, M. Erdélyi (2017). TestSTORM: Versatile simulator software for multimodal super-resolution localization fluorescence microscopy. Scientific reports, 7(1), 951. Q1 IF : 4,445 (2017); doi:10.1038/s41598-017-01122-7

\section{Konferencia előadás és poszter}

[E1] T. Gajdos, Zs. Cserteg, Sz. Szikora, T. Novák, B. B. H. Kovács, G. Szabó, J. Mihály, M. Erdélyi (2019) Lokalizációs mikroszkópia több modalitásban a laterális pontosság megőrzése mellett. MMT Konferencia, 2019.05.23-25., Siófok 
[P1] Zs. Farkas, T. Gajdos, B. Major, A. Nagy (2011). Ages and Scientists. Science on Stage Festival, 2011.04.16-19., Koppenhága, Dánia

[P2] T. Gajdos, J. Németh, J. Sinkó, D. Varga, E. J. Rees, G. Szabó, M. Erdélyi (2016) Localization analysis with rainSTORM. 16th international ELMI meeting, 2016.05.2427., Debrecen

[P3] T. Gajdos, J. Németh, J. Sinkó, D. Varga, E. J. Rees, G. Szabó, M. Erdélyi (2016) Localization analysis with rainSTORM. 6th Single Molecule Localization Microscopy Symposium, 2016.08.28-30., Lausanne, Svájc

[P4] T. Gajdos, T. Novák, Zs. Cserteg, M. Erdélyi (2017) Multimodal localization based super-resolution microscopy with efficient photon collection. MMC2017, 2017.07.36., Manchester, Egyesült Királyság

[P5] T. Gajdos, T. Novák, Zs. Cserteg, M. Erdélyi (2017) Multimodal localization based super-resolution microscopy with efficient photon collection. MBFT XXVI. Kongresszus, 2017.08.22-25., Szeged

[P6] T. Gajdos, T. Novák, Zs. Cserteg, M. Erdélyi (2018) Multimodális lokalizációs mikroszkóp effektív fotongyüjtéssel. Kvantumelektronika 2018, 2018.06.15., Budapest

[P7] T. Gajdos, Zs. Cserteg, Sz. Szikora, J. Mihály, B. B. H. Kovács, T. Novák, M. Erdélyi (2019) Multimodal localization microscopy with efficient photon collection., FOM2019, 2019.04.14-17., London, Egyesült Királyság

\section{Fejlesztett programok listája}

[S1] Arduino Laser Driver (C, LabView), saját, egyéni munka. https://github.com/gajdipajti/thorlabs-ldc-arduino

[S2] Arduino Stepper Control (C, LabView), saját, egyéni munka. https://github.com/gajdipajti/arduino_stepper_control

[S3] IFM Analyser, (Mathworks Matlab), megosztott munka. http://titan.physx.u-szeged.hu/ adoptim/?page_id=1246

[S4] rainSTORM (Mathworks Matlab), kisebb fejlesztések, részfeladatok. http://titan.physx.u-szeged.hu/ adoptim/?page_id=582

[S5] Beam Profiler (Python), kisebb fejlesztések. https://gist.github.com/gajdipajti/0ff1625115137866ca10f5cec136bed6

[S6] mmSTORM-ast-lense (LabView), hallgatóm munkája. https://gitlab.com/adoptim/mmSTORM-ast-lense 


\section{Hivatkozások}

[1] URL https://de.wikipedia.org/wiki/Datei:Ernst_Abbe_memorial.JPG. 2019.01.31.

[2] A. Acuna, F. Amat-Guerri, in Fluorescence of supermolecules, polymers, and nanosystems (Springer, 2007), pp. 3-20. doi:10.1007/4243_2007_006

[3] D. Brewster, XIX. On the Colours of Natural Bodies, Transactions of the Royal Society of Edinburgh 12(2), 538 (1834). doi:10.1017/s0080456800031203

[4] B. Valeur, M.N. Berberan-Santos, A Brief History of Fluorescence and Phosphorescence before the Emergence of Quantum Theory, Journal of Chemical Education 88(6), 731 (2011). doi:10.1021/ed100182h

[5] J.F.W. Herschel, On a case of superficial colour presented by a homogeneous liquid internally colourless, Philosophical Transactions of the Royal Society of London 135, 143 (1845). doi:10.1098/rstl.1845.0004

[6] G.G. Stokes, XXX. On the change of refrangibility of light, Philosophical Transactions of the Royal Society of London 142, 463 (1852). doi:10.1098/rstl.1852.0022

[7] M. Kasha, Characterization of electronic transitions in complex molecules, Discussions of the Faraday Society 9, 14 (1950). doi:10.1039/df9500900014

[8] A. Jablonski, Efficiency of Anti-Stokes Fluorescence in Dyes, Nature 131(3319), 839 (1933). doi:10.1038/131839b0

[9] J.R. Lakowicz, Principles of fluorescence spectroscopy, 3rd edn. (Springer Science \& Business Media, 2006). doi:10.1007/978-0-387-46312-4. P:1-26;98-158;257$264 ; 353-383$;

[10] R. Kubin, A. Fletcher, Fluorescence quantum yields of some rhodamine dyes, Journal of Luminescence 27(4), 455 (1982). doi:10.1016/0022-2313(82)90045-x

[11] URL https://www.thermof isher.com/hu/en/home/ references/molecular-probes-the-handbook/tables/ fluorescence-quantum-yields-and-lifetimes-for-alexa-fluor-dyes.html. 2019.01.31.

[12] URL http://www.iss.com/resources/reference/data_tables/ LifetimeDataFluorophores.html. 2019.01.31.

[13] J. Pawley, Handbook of biological confocal microscopy (Springer Science \& Business Media, 2010)

[14] M. Monici, in Biotechnology Annual Review (Elsevier, 2005), pp. 227-256. doi:10.1016/s1387-2656(05)11007-2 
[15] W. Baschong, R. Suetterlin, R.H. Laeng, Control of Autofluorescence of Archival Formaldehyde-fixed, Paraffin-embedded Tissue in Confocal Laser Scanning Microscopy (CLSM), Journal of Histochemistry \& Cytochemistry 49(12), 1565 (2001). doi: $10.1177 / 002215540104901210$

[16] L.D. Landau, in Collected Papers of L.D. Landau (Elsevier, 1965), pp. 461-465. doi:10.1016/b978-0-08-010586-4.50067-5

[17] R. Wood, XXIX.Anti-Stokes radiation of fluorescent liquids, The London, Edinburgh, and Dublin Philosophical Magazine and Journal of Science 6(35), 310 (1928). doi:10.1080/14786440808564606

[18] C.A. Parker, C.G. Hatchard, Delayed fluorescence of pyrene in ethanol, Transactions of the Faraday Society 59, 284 (1963). doi:10.1039/tf9635900284

[19] J.B. Birks, On the delayed fluorescence of pyrene solutions, The Journal of Physical Chemistry 67(10), 2199 (1963). doi:10.1021/j100804a054

[20] M. Göppert-Mayer, Über Elementarakte mit zwei Quantensprüngen, Annalen der Physik 401(3), 273 (1931). doi:10.1002/andp.19314010303

[21] X. Zhu, Q. Su, W. Feng, F. Li, Anti-Stokes shift luminescent materials for bioapplications, Chemical Society Reviews 46(4), 1025 (2017). doi:10.1039/c6cs00415f

[22] L. Erickson, On anti-stokes luminescence from Rhodamine 6G in ethanol solutions, Journal of Luminescence 5(1), 1 (1972). doi:10.1016/0022-2313(72)90030-0

[23] C.A. Parker, C.G. Hatchard, Triplet-singlet emission in fluid solutions. Phosphorescence of eosin, Transactions of the Faraday Society 57, 1894 (1961). doi:10.1039/tf9615701894

[24] F.B. Dias, T.J. Penfold, A.P. Monkman, Photophysics of thermally activated delayed fluorescence molecules, Methods and Applications in Fluorescence 5(1), 012001 (2017). doi:10.1088/2050-6120/aa537e

[25] W. Blau, W. Dankesreiter, A. Penzkofer, Saturable absorption of dyes excited to the long-wavelength region of the $S_{0}-S_{1}$ absorption band, Chemical Physics 85(3), 473 (1984). doi:10.1016/0301-0104(84)85273-8

[26] J.L. Clark, P.F. Miller, G. Rumbles, Red Edge Photophysics of Ethanolic Rhodamine 101 and the Observation of Laser Cooling in the Condensed Phase, The Journal of Physical Chemistry A 102(24), 4428 (1998). doi:10.1021/jp980589c

[27] Y. Liu, Q. Su, M. Chen, Y. Dong, Y. Shi, W. Feng, Z.Y. Wu, F. Li, Near-Infrared Upconversion Chemodosimeter for In Vivo Detection of $\mathrm{Cu}^{2+}$ in Wilson Disease, Advanced Materials 28(31), 6625 (2016). doi:10.1002/adma.201601140 
[28] A.V. Kachynski, A.N. Kuzmin, H.E. Pudavar, P.N. Prasad, Three-dimensional confocal thermal imaging using anti-Stokes luminescence, Applied Physics Letters 87(2), 023901 (2005). doi:10.1063/1.1993761

[29] R.K. Jain, C. Hu, T.K. Gustafson, S.S. Elliot, M.S. Chang, Absorption processes associated with anti-Stokes fluorescence in rhodamine B solutions, Journal of Applied Physics 44(7), 3157 (1973). doi:10.1063/1.1662724

[30] S. Kumazaki, Anti-Stokes fluorescence of oxazine 1 in solution with continuous wave laser excitation at 785nm, Chemical Physics 419, 107 (2013). doi:10.1016/j.chemphys.2013.02.030

[31] Y.P. Meshalkin, V.A. Svetlichnyi, I.N. Lapin, Anti-stokes fluorescence of polymethine dyes excited by a titanium-sapphire laser, Russian Physics Journal 50(3), 267 (2007). doi:10.1007/s11182-007-0037-0

[32] URL https://www.chroma.com/spectra-viewer?fluorochromes=10373\% 2C10375. 2019.01.31.

[33] T. Forster, Energiewanderung und Fluoreszenz, Die Naturwissenschaften 33(6), 166 (1946). doi:10.1007/bf00585226

[34] M.A. Lauterbach, Finding, defining and breaking the diffraction barrier in microscopy - a historical perspective, Optical Nanoscopy 1(1), 8 (2012). doi:10.1186/21922853-1-8

[35] K. Strehl, Aplanatische und fehlerhafte Abbildung im Fernrohr, Zeitschrift für Instrumentenkunde 15, 362 (1895)

[36] K. Strehl, Über luftschlieren und zonenfehler, Zeitschrift für Instrumentenkunde 22, $213(1902)$

[37] URL numerical-aperture, 2019.01.31.

https://www.microscopyu.com/microscopy-basics/

[38] N. Bourg, C. Mayet, G. Dupuis, T. Barroca, P. Bon, S. Lécart, E. Fort, S. LévêqueFort, Direct optical nanoscopy with axially localized detection, Nature Photonics 9(9), 587 (2015). doi:10.1038/nphoton.2015.132

[39] C. Sheppard, T. Wilson, Image Formation in Scanning Microscopes with Partially Coherent Source and Detector, Optica Acta: International Journal of Optics 25(4), 315 (1978). doi:10.1080/713819784

[40] T. Funatsu, Y. Harada, M. Tokunaga, K. Saito, T. Yanagida, Imaging of single fluorescent molecules and individual ATP turnovers by single myosin molecules in aqueous solution, Nature 374(6522), 555 (1995). doi:10.1038/374555a0 
[41] Y. Sako, S. Minoghchi, T. Yanagida, Single-molecule imaging of EGFR signalling on the surface of living cells, Nature Cell Biology 2(3), 168 (2000). doi: $10.1038 / 35004044$

[42] D. Axelrod, Total Internal Reflection Fluorescence Microscopy in Cell Biology, Traffic 2(11), 764 (2001). doi:10.1034/j.1600-0854.2001.21104.x

[43] C.B. Müller, J. Enderlein, Image Scanning Microscopy, Physical Review Letters 104(19) (2010). doi:10.1103/physrevlett.104.198101

[44] I. Gregor, J. Enderlein, Image scanning microscopy, Current opinion in chemical biology 51, 74 (2019). doi:10.1016/j.cbpa.2019.05.011

[45] G.M.D. Luca, R.M. Breedijk, R.A. Brandt, C.H. Zeelenberg, B.E. de Jong, W. Timmermans, L.N. Azar, R.A. Hoebe, S. Stallinga, E.M. Manders, Re-scan confocal microscopy: scanning twice for better resolution, Biomedical Optics Express 4(11), 2644 (2013). doi:10.1364/boe.4.002644

[46] M.G.L. Gustafsson, Surpassing the lateral resolution limit by a factor of two using structured illumination microscopy. Short Communication, Journal of Microscopy 198(2), 82 (2000). doi:10.1046/j.1365-2818.2000.00710.x

[47] A.I. Fernández-Domínguez, Z. Liu, J.B. Pendry, Coherent Four-Fold SuperResolution Imaging with Composite Photonic-Plasmonic Structured Illumination, ACS Photonics 2(3), 341 (2015). doi:10.1021/ph500342g

[48] S. Hell, E.H.K. Stelzer, Properties of a $4 P i$ confocal fluorescence microscope, Journal of the Optical Society of America A 9(12), 2159 (1992). doi:10.1364/josaa.9.002159

[49] Gustafsson, Agard, Sedat, I5M: 3D widefield light microscopy with better than 100 nm axial resolution, Journal of Microscopy 195(1), 10 (1999). doi:10.1046/j.13652818.1999.00576.x

[50] S. Shashkova, M.C. Leake, Single-molecule fluorescence microscopy review: shedding new light on old problems, Bioscience Reports 37(4), BSR20170031 (2017). doi: $10.1042 /$ bsr20170031

[51] A. Lee, K. Tsekouras, C. Calderon, C. Bustamante, S. Pressé, Unraveling the Thousand Word Picture: An Introduction to Super-Resolution Data Analysis, Chemical Reviews 117(11), 7276 (2017). doi:10.1021/acs.chemrev.6b00729

[52] L. Schermelleh, A. Ferrand, T. Huser, C. Eggeling, M. Sauer, O. Biehlmaier, G.P.C. Drummen, Super-resolution microscopy demystified, Nature Cell Biology 21(1), 72 (2019). doi:10.1038/s41556-018-0251-8

[53] A. Jimenez, K. Friedl, C. Leterrier, About samples, giving examples: Optimized Single Molecule Localization Microscopy, Methods (2019). doi:10.1016/j.ymeth.2019.05.008 
[54] S.W. Hell, J. Wichmann, Breaking the diffraction resolution limit by stimulated emission: stimulated-emission-depletion fluorescence microscopy, Optics Letters 19(11), 780 (1994). doi:10.1364/ol.19.000780

[55] S.W. Hell, Far-Field Optical Nanoscopy, Science 316(5828), 1153 (2007). doi:10.1126/science.1137395

[56] D. Wildanger, R. Medda, L. Kastrup, S.W. Hell, A compact STED microscope providing 3D nanoscale resolution, Journal of Microscopy 236(1), 35 (2009). doi:10.1111/j.1365-2818.2009.03188.x

[57] F. Balzarotti, Y. Eilers, K.C. Gwosch, A.H. Gynnå, V. Westphal, F.D. Stefani, J. Elf, S.W. Hell, Nanometer resolution imaging and tracking of fluorescent molecules with minimal photon fluxes, Science 355(6325), 606 (2016). doi:10.1126/science.aak9913

[58] K.C. Gwosch, J.K. Pape, F. Balzarotti, P. Hoess, J. Ellenberg, J. Ries, S.W. Hell, MINFLUX nanoscopy delivers 3D multicolor nanometer resolution in cells, Nature Methods pp. 1-8 (2020). doi:10.1038/s41592-019-0688-0

[59] C. Kural, Kinesin and Dynein Move a Peroxisome in Vivo: A Tug-of-War or Coordinated Movement?, Science 308(5727), 1469 (2005). doi:10.1126/science.1108408

[60] J. Gelles, B.J. Schnapp, M.P. Sheetz, Tracking kinesin-driven movements with nanometre-scale precision, Nature 331(6155), 450 (1988). doi:10.1038/331450a0

[61] A. Yildiz, Myosin V Walks Hand-Over-Hand: Single Fluorophore Imaging with 1.5nm Localization, Science 300(5628), 2061 (2003). doi:10.1126/science.1084398

[62] E. Betzig, G.H. Patterson, R. Sougrat, O.W. Lindwasser, S. Olenych, J.S. Bonifacino, M.W. Davidson, J. Lippincott-Schwartz, H.F. Hess, Imaging Intracellular Fluorescent Proteins at Nanometer Resolution, Science 313(5793), 1642 (2006). doi:10.1126/science.1127344

[63] S.T. Hess, T.P. Girirajan, M.D. Mason, Ultra-High Resolution Imaging by Fluorescence Photoactivation Localization Microscopy, Biophysical Journal 91(11), 4258 (2006). doi:10.1529/biophysj.106.091116

[64] R.M. Dickson, A.B. Cubitt, R.Y. Tsien, W.E. Moerner, On/off blinking and switching behaviour of single molecules of green fluorescent protein, Nature 388(6640), 355 (1997). doi:10.1038/41048

[65] S.W. Hell, M. Kroug, Ground-state-depletion fluorscence microscopy: A concept for breaking the diffraction resolution limit, Applied Physics B Lasers and Optics 60(5), 495 (1995). doi:10.1007/bf01081333

[66] J. Fölling, M. Bossi, H. Bock, R. Medda, C.A. Wurm, B. Hein, S. Jakobs, C. Eggeling, S.W. Hell, Fluorescence nanoscopy by ground-state depletion and singlemolecule return, Nature Methods 5(11), 943 (2008). doi:10.1038/nmeth.1257 
[67] M.J. Rust, M. Bates, X. Zhuang, Sub-diffraction-limit imaging by stochastic optical reconstruction microscopy (STORM), Nature Methods 3(10), 793 (2006). doi:10.1038/nmeth929

[68] M. Heilemann, S. van de Linde, M. Schüttpelz, R. Kasper, B. Seefeldt, A. Mukherjee, P. Tinnefeld, M. Sauer, Subdiffraction-Resolution Fluorescence Imaging with Conventional Fluorescent Probes, Angewandte Chemie International Edition 47(33), 6172 (2008). doi:10.1002/anie.200802376

[69] M. Heilemann, E. Margeat, R. Kasper, M. Sauer, P. Tinnefeld, Carbocyanine Dyes as Efficient Reversible Single-Molecule Optical Switch, Journal of the American Chemical Society 127(11), 3801 (2005). doi:10.1021/ja044686x

[70] M. Bates, T.R. Blosser, X. Zhuang, Short-Range Spectroscopic Ruler Based on a Single-Molecule Optical Switch, Physical Review Letters 94(10) (2005). doi:10.1103/physrevlett.94.108101

[71] S. van de Linde, A. Löschberger, T. Klein, M. Heidbreder, S. Wolter, M. Heilemann, M. Sauer, Direct stochastic optical reconstruction microscopy with standard fluorescent probes, Nature Protocols 6(7), 991 (2011). doi:10.1038/nprot.2011.336

[72] G.T. Dempsey, J.C. Vaughan, K.H. Chen, M. Bates, X. Zhuang, Evaluation of fluorophores for optimal performance in localization-based super-resolution imaging, Nature Methods 8(12), 1027 (2011). doi:10.1038/nmeth.1768

[73] J.K.G. Karlsson, A. Laude, M.J. Hall, A. Harriman, Photo-isomerization of the Cyanine Dye Alexa-Fluor 647 (AF-647) in the Context of dSTORM SuperResolution Microscopy, Chemistry - A European Journal 25(65), 14983 (2019). doi:10.1002/chem.201904117

[74] A. Sharonov, R.M. Hochstrasser, Wide-field subdiffraction imaging by accumulated binding of diffusing probes, Proceedings of the National Academy of Sciences 103(50), 18911 (2006). doi:10.1073/pnas.0609643104

[75] R. Jungmann, C. Steinhauer, M. Scheible, A. Kuzyk, P. Tinnefeld, F.C. Simmel, Single-Molecule Kinetics and Super-Resolution Microscopy by Fluorescence Imaging of Transient Binding on DNA Origami, Nano Letters 10(11), 4756 (2010). doi:10.1021/nl103427w

[76] T. Schmidt, G.J. Schutz, W. Baumgartner, H.J. Gruber, H. Schindler, Imaging of single molecule diffusion., Proceedings of the National Academy of Sciences 93(7), 2926 (1996). doi:10.1073/pnas.93.7.2926

[77] S. Stallinga, B. Rieger, Accuracy of the Gaussian Point Spread Function model in 2D localization microscopy, Optics Express 18(24), 24461 (2010). doi:10.1364/oe.18.024461 
[78] A. Small, S. Stahlheber, Fluorophore localization algorithms for super-resolution microscopy, Nature Methods 11(3), 267 (2014). doi:10.1038/nmeth.2844

[79] K.A. Lidke, B. Rieger, T.M. Jovin, R. Heintzmann, Superresolution by localization of quantum dots using blinking statistics, Optics Express 13(18), 7052 (2005). doi:10.1364/opex.13.007052

[80] URL http://bigwww.epfl.ch/smlm/software/index.html. 2019.01.31.

[81] E.J. Rees, M. Erdelyi, G.S.K. Schierle, A. Knight, C.F. Kaminski, Elements of image processing in localization microscopy, Journal of Optics 15(9), 094012 (2013). doi:10.1088/2040-8978/15/9/094012

[82] D. Sage, T.A. Pham, H. Babcock, T. Lukes, T. Pengo, J. Chao, R. Velmurugan, A. Herbert, A. Agrawal, S. Colabrese, A. Wheeler, A. Archetti, B. Rieger, R. Ober, G.M. Hagen, J.B. Sibarita, J. Ries, R. Henriques, M. Unser, S. Holden, Superresolution fight club: assessment of $2 D$ and $3 D$ single-molecule localization microscopy software, Nature Methods 16(5), 387 (2019). doi:10.1038/s41592-019-0364-4

[83] R.E. Thompson, D.R. Larson, W.W. Webb, Precise Nanometer Localization Analysis for Individual Fluorescent Probes, Biophysical Journal 82(5), 2775 (2002). doi:10.1016/s0006-3495(02)75618-x

[84] H. Deschout, F.C. Zanacchi, M. Mlodzianoski, A. Diaspro, J. Bewersdorf, S.T. Hess, K. Braeckmans, Precisely and accurately localizing single emitters in fluorescence microscopy, Nature Methods 11(3), 253 (2014). doi:10.1038/nmeth.2843

[85] S.W. Hell, S.J. Sahl, M. Bates, X. Zhuang, R. Heintzmann, M.J. Booth, J. Bewersdorf, G. Shtengel, H. Hess, P. Tinnefeld, A. Honigmann, S. Jakobs, I. Testa, L. Cognet, B. Lounis, H. Ewers, S.J. Davis, C. Eggeling, D. Klenerman, K.I. Willig, G. Vicidomini, M. Castello, A. Diaspro, T. Cordes, The 2015 super-resolution microscopy roadmap, Journal of Physics D: Applied Physics 48(44), 443001 (2015). doi:10.1088/0022-3727/48/44/443001

[86] K.I. Mortensen, L.S. Churchman, J.A. Spudich, H. Flyvbjerg, Optimized localization analysis for single-molecule tracking and super-resolution microscopy, Nature Methods 7(5), 377 (2010). doi:10.1038/nmeth.1447

[87] R.J. Ober, S. Ram, E.S. Ward, Localization Accuracy in Single-Molecule Microscopy, Biophysical Journal 86(2), 1185 (2004). doi:10.1016/s0006-3495(04)74193-4

[88] E.J. Rees, M. Erdelyi, D. Pinotsi, A. Knight, D. Metcalf, C.F. Kaminski, Blind assessment of localisation microscope image resolution, Optical Nanoscopy 1(1), 12 (2012). doi:10.1186/2192-2853-1-12

[89] H. Kao, A. Verkman, Tracking of single fluorescent particles in three dimensions: use of cylindrical optics to encode particle position, Biophysical Journal 67(3), 1291 (1994). doi:10.1016/s0006-3495(94)80601-0 
[90] B. Huang, W. Wang, M. Bates, X. Zhuang, Three-Dimensional Super-Resolution Imaging by Stochastic Optical Reconstruction Microscopy, Science 319(5864), 810 (2008). doi:10.1126/science.1153529

[91] E. Toprak, H. Balci, B.H. Blehm, P.R. Selvin, Three-Dimensional Particle Tracking via Bifocal Imaging, Nano Letters 7(7), 2043 (2007). doi:10.1021/nl0709120

[92] M.F. Juette, T.J. Gould, M.D. Lessard, M.J. Mlodzianoski, B.S. Nagpure, B.T. Bennett, S.T. Hess, J. Bewersdorf, Three-dimensional sub-100 nm resolution fluorescence microscopy of thick samples, Nature Methods 5(6), 527 (2008). doi: $10.1038 /$ nmeth.1211

[93] S.R.P. Pavani, R. Piestun, High-efficiency rotating point spread functions, Optics Express 16(5), 3484 (2008). doi:10.1364/oe.16.003484

[94] S.R.P. Pavani, M.A. Thompson, J.S. Biteen, S.J. Lord, N. Liu, R.J. Twieg, R. Piestun, W.E. Moerner, Three-dimensional, single-molecule fluorescence imaging beyond the diffraction limit by using a double-helix point spread function, Proceedings of the National Academy of Sciences 106(9), 2995 (2009). doi:10.1073/pnas.0900245106

[95] C. Franke, M. Sauer, S. van de Linde, Photometry unlocks 3D information from 2D localization microscopy data, Nature Methods 14(1), 41 (2016). doi: $10.1038 /$ nmeth.4073

[96] T. Barroca, K. Balaa, S. Lévêque-Fort, E. Fort, Full-Field Near-Field Optical Microscope for Cell Imaging, Physical Review Letters 108(21) (2012). doi:10.1103/physrevlett.108.218101

[97] M.A. Lieb, J.M. Zavislan, L. Novotny, Single-molecule orientations determined by direct emission pattern imaging, Journal of the Optical Society of America B 21(6), 1210 (2004). doi:10.1364/josab.21.001210

[98] A.S. Backer, M.Y. Lee, W. Moerner, Enhanced DNA imaging using super-resolution microscopy and simultaneous single-molecule orientation measurements, Optica 3(6), 659 (2016). doi:10.1364/OPTICA.3.000659

[99] G. Harms, M. Sonnleitner, G. Schütz, H. Gruber, T. Schmidt, Single-Molecule Anisotropy Imaging, Biophysical Journal 77(5), 2864 (1999). doi:10.1016/s00063495(99)77118-3

[100] C.A.V. Cruz, H.A. Shaban, A. Kress, N. Bertaux, S. Monneret, M. Mavrakis, J. Savatier, S. Brasselet, Quantitative nanoscale imaging of orientational order in biological filaments by polarized superresolution microscopy, Proceedings of the National Academy of Sciences 113(7), E820 (2016). doi:10.1073/pnas.1516811113 
[101] I. Testa, C.A. Wurm, R. Medda, E. Rothermel, C. von Middendorf, J. Fölling, S. Jakobs, A. Schönle, S.W. Hell, C. Eggeling, Multicolor Fluorescence Nanoscopy in Fixed and Living Cells by Exciting Conventional Fluorophores with a Single Wavelength, Biophysical Journal 99(8), 2686 (2010). doi:10.1016/j.bpj.2010.08.012

[102] A. Lampe, V. Haucke, S.J. Sigrist, M. Heilemann, J. Schmoranzer, Multi-colour direct STORM with red emitting carbocyanines, Biology of the Cell 104(4), 229 (2012). doi:10.1111/boc.201100011

[103] Z. Zhang, S.J. Kenny, M. Hauser, W. Li, K. Xu, Ultrahigh-throughput single-molecule spectroscopy and spectrally resolved super-resolution microscopy, Nature Methods 12(10), 935 (2015). doi:10.1038/nmeth.3528

[104] M.J. Mlodzianoski, N.M. Curthoys, M.S. Gunewardene, S. Carter, S.T. Hess, Super-Resolution Imaging of Molecular Emission Spectra and Single Molecule Spectral Fluctuations, PLOS ONE 11(3), e0147506 (2016). doi:10.1371/journal.pone.0147506

[105] M.N. Bongiovanni, J. Godet, M.H. Horrocks, L. Tosatto, A.R. Carr, D.C. Wirthensohn, R.T. Ranasinghe, J.E. Lee, A. Ponjavic, J.V. Fritz, C.M. Dobson, D. Klenerman, S.F. Lee, Multi-dimensional super-resolution imaging enables surface hydrophobicity mapping, Nature Communications 7(1) (2016). doi:10.1038/ncomms13544

[106] B. Dong, B.T. Soetikno, X. Chen, V. Backman, C. Sun, H.F. Zhang, Parallel Three-Dimensional Tracking of Quantum Rods Using Polarization-Sensitive Spectroscopic Photon Localization Microscopy, ACS Photonics 4(7), 1747 (2017). doi:10.1021/acsphotonics.7b00294

[107] K.H. Song, Y. Zhang, G. Wang, C. Sun, H.F. Zhang, Three-dimensional biplane spectroscopic single-molecule localization microscopy, Optica 6(6), 709 (2019). doi:10.1364/optica.6.000709

[108] J. Sinkó, G. Szabó, M. Erdélyi, Ray tracing analysis of inclined illumination techniques, Optics express 22(16), 18940 (2014). doi:10.1364/OE.22.018940

[109] URL https://www.microscope.healthcare.nikon.com/selectors/ objective-comparison/-1932-1854-1708, 2019.01.31.

[110] Advanced Optical Imaging Group, rainSTORM Blind Drift Correction, 2019th edn. URL http://titan.physx.u-szeged.hu/ adoptim/wp-content/uploads/2019/ 05/rainSTORM-blind-drift-correction.pdf

[111] X. Wang, A. Kress, S. Brasselet, P. Ferrand, High frame-rate fluorescence confocal angle-resolved linear dichroism microscopy, Review of Scientific Instruments 84(5), 053708 (2013). doi:10.1063/1.4807318 
[112] T. Azumi, K.i. Itoh, H. Shiraishi, Shift of emission band upon the excitation at the long wavelength absorption edge. III. Temperature dependence of the shift and correlation with the time dependent spectral shift, The Journal of Chemical Physics 65(7), 2550 (1976). doi:10.1063/1.433440

[113] A.P. Demchenko, The red-edge effects: 30 years of exploration, Luminescence: the journal of biological and chemical luminescence 17(1), 19 (2002). doi: $10.1002 /$ bio. 671

[114] V.I. Tomin, in Advanced Fluorescence Reporters in Chemistry and Biology I (Springer, 2010), pp. 189-223. doi:10.1007/978-3-642-04702-2_6

[115] D.K. Chatterjee, A.J. Rufaihah, Y. Zhang, Upconversion fluorescence imaging of cells and small animals using lanthanide doped nanocrystals, Biomaterials 29(7), 937 (2008). doi:10.1016/j.biomaterials.2007.10.051

[116] C.Y.M. Huang, C. Zhang, T.S.Y. Ho, J. Oses-Prieto, A.L. Burlingame, J. Lalonde, J.L. Noebels, C. Leterrier, M.N. Rasband, aII Spectrin Forms a Periodic Cytoskeleton at the Axon Initial Segment and Is Required for Nervous System Function, The Journal of Neuroscience 37(47), 11311 (2017). doi:10.1523/jneurosci.2112-17.2017

[117] H. Li, Y. Capetanaki, Regulation of the mouse desmin gene: transactivation by MyoD, myogenin, MRF4 and Myf5, Nucleic Acids Research 21(2), 335 (1993). doi:10.1093/nar/21.2.335

[118] R. McColl, M. Nkosi, C. Snyman, C. Niesler, Analysis and quantification of in vitro myoblast fusion using the LADD Multiple Stain, BioTechniques 61(6) (2016). doi:10.2144/000114485

[119] A. Balinovic, D. Albrecht, U. Endesfelder, Spectrally red-shifted fluorescent fiducial markers for optimal drift correction in localization microscopy, Journal of Physics D: Applied Physics 52(20), 204002 (2019). doi:10.1088/1361-6463/ab0862

[120] OSLO, Optics Reference. Lambda Research Corp. Littleton MA USA., 2011th edn. URL https://www.lambdares.com/wp-content/uploads/support/oslo/ oslo_edu/oslo-optics-reference.pdf

[121] J.M. Squire, H.A. Al-khayat, C. Knupp, P.K. Luther, in Advances in Protein Chemistry (Elsevier, 2005), pp. 17-87. doi:10.1016/s0065-3233(04)71002-5 